\title{
EFEITO DA Crotalaria juncea Linn. NA EFICIÊNCIA AGRONÔMICA, ECONÔMICA E ENERGÉTICA DE CULTURAS EM SUCESSÃO SOB PLANTIO DIRETO
}

\section{Elir de Oliveira}

Engenheiro Agrônomo

Orientador: Prof. Dr. Antonio Luiz Fancelli

Dissertação apresentada à Escola Superior de Agricultura "Luiz de Queiroz", da Universidade de São Paulo, para obtenção do título de Mestre em Agronomia, Área de concentração: Fitotecnia.

PIRACICABA

Estado de São Paulo - Brasil

Junho - 1996 
Dados Internacionais de Catalogação na Publicação (CIP) DIVISÃO DE BIBLIOTECA E DOCUMENTAÇĀO - Campus “Luiz de Queiroz"/USP

Oliveira, Elir de

Efeito da Crotalaria juncea Linn. na eficiência agronơmica, econơmica e energética de culturas em sucessão sob plantio direito / Elir de Oliveira. - - Piracicaba, 1996.

95p. : II.

Dissertaçåo (mestrado) - - Escola Superior de Agricultura Luiz de Queiroz, 1996.

Bibliografia.

1. Adubo verde 2. Canhamo-da-india - Adubação verde 3. Crotalaria como adubo verde 4. Plantio direto $I$. Título 
EFEITO DA Crotalaria juncea Linn. NA EFICIENCIA AGRONÔMICA, ECONÔMICA E ENERGÉTICA DE CULTURAS EM SUCESSÃO SOB PLANTIO DIRETO

ELIR DE OLIVEIRA

Aprovada em: 28.08.1996

Comissão julgadora:

Prof. Dr. Antonio Luiz Fancelli

ESALQ/USP

Prof. Dr. José Dias Costa

ESALQ/USP

Dr. Eduardo Antonio Bulisani

IAC/CPA

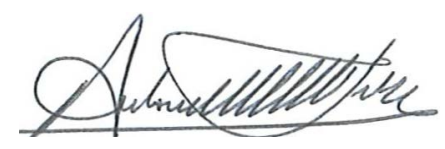

Prof. Dr. ANTONIO LUIZ FANCELLI Orientador 
À minha esposa Madelaine e aos nossos filhos Alan e Ellen. Pelo apoio, compreensão e carinho, Dedico. Aos meus pais
Geraldo Cândido de Oliveira e
Maria de Souza Oliveira
(in memorian). Meu reconhecimento e gratidão.

Aos meus sogros Lourdes e Aldo Riedi. Meus agradecimentos. 


\section{Agradecimentos}

- Ao Prof. Dr. Antonio Luiz Fancelli, pela orientação e amizade.

- Aos pesquisadores do IAPAR-Instituto Agronômico do Paraná, Garibaldi Batista de Medeiros e Mário Miyazawa, pela discussão e auxílio nas análises de solo.

- Ao Prof. Dr. José Dias Costa, do Depto. de Agricultura-ESALQ, pela experiência repassada.

- Ao CENA - Centro de Energia Nuclear na Agricultura, através dos técnicos Sandra Genaro Nicoletti e José Roberto Martins, pelo repasse da metodologia de fracionamento de matéria orgânica.

- Aos pesquisadores do IAPAR-Instituto Agronômico do Paraná, Carlos Roberto Riede, Paulo Roberto A. Figueiredo, Moacyr Doretto, Antonio Carlos Laurenti, pelo auxílio e sugestões.

- Ao Prof. Dr. Carlos Tadeu dos Santos Dias, do Depto. de Matematática e Estatística-ESALQ, pelas suegestões.

- Ao pesquisador da EMBRAPA/CNPSo, Celso Gaudêncio, pelas sugestões e incentivo no início do trabalho. 
LISTA DE FIGURAS viii

LISTA DE TABELAS $\quad x$

LISTA DE TABELAS-APÊNDICE

RESUMO xiii

SUMMARY xvi

1. INTRODUÇÃO 1

2. REVISÃO DE LITERATURA 4

2.1. Características edafoclimáticas da região 4

2.2. Práticas tradicionais demanejo de solo 5

2.3. Sistema de plantio direto 6

2.4. Rotação de culturas 10

2.5. Adubação verde 15

2.6. Crotalaria juncea Linn. 18

3. MATERIAL E MÉTODOS 22

3.1. Área experimental 22

3.1.1. Amostragem do solo e análises 22

3.1.2. Unidade experimental 24

3.2. Clima 24

3.3. Sistemas de sucessões de culturas e adubação mineral 27

3.3.1. Cultivares utilizados 28

3.4. Manejo da adubação verde 29

3.5. Manejo do solo e das culturas $\quad 29$

3.6. Desempenho econômico dos sistemas 30

3.7. Análise do balanço energético 31

3.8. Parâmetros avaliados e análises estatísticas 31 
3.8.1. Rendimento de grãos 32

3.8.2. Composição química do solo 32

3.8.3. Análise da estabilidade dos agregados 32

3.8.4. População de plantas daninhas 32

3.8.5. Avaliação dos resultados econômicos dos sistemas 33

3.8.6. Balanço energético 33

\section{RESULTADOS E DISCUSSÃ O 34}

4.1. Rendimentos de grãos de trigo, soja e milho 34

4.1.1. Comportamento do trigo 35

4.1.2. Comportamento do milho 36

4.1.3. Comportamento da soja 37

4.2. Resultados das análises químicas e física do solo 44

4.2.1. Comportamento do $\mathrm{pH}$ do solo 45

4.2.2. Comportamento do Fósforo (P) 46

4.2.3. Comportamento do Cálcio $(\mathrm{Ca}) \quad 46$

4.2.4. Comportamento do Potássio (K) 47

4.2.5. Comportamento da estabilidade dos agregados 47

4.2.6. Comportamento da Matéria Orgânica do solo 48

4.3. Resultados de produção de matéria seca da crotalária $\quad 50$

4.4. Avaliação da população de plantas daninhas 51

4.5. Avaliação econômica dos sistemas de produção 53

4.5.1. Desempenho econômico da cultura do trigo 54

4.5.2. Desempenho econômico da cultura da soja 55

4.5.3. Desempenho econômico da cultura do milho 56

4.5.4. Economia pela redução do uso de herbicidas 56

4.5.5. Balanço econômico dos sistemas de produção 57

4.6. Balanço energético 58 
4.6.1. Balanço energético da cultura da soja 59

4.6.2. Balanço energético da cultura do milho 60

4.6.3. Balanço energético da cultura do trigo 60

4.6.4. Balanço energético dos sistemas de produção 61

5. CONCLUSÕES 62

6. REFERÊNCIAS BIBLIOGRÁFICAS 64

APÊNDICE 
1. Distribuição da precipitação pluvial de mai/91 a abr/92 24

2. Temperaturas mínimas e máximas de mai/91 a abr/92 24

3 Distribuição da precipitação pluvial de mai/92 a abr/93 25

4 Temperaturas mínimas e máximas de mai/92 a abr/93 25

5 Distribuição da precipitação pluvial de mai/93 a abr/94 25

6 Temperaturas mínimas e máximas de mai/93 a abr/94 25

7 Distribuição da precipitação pluvial de mai/94 a abr/95 26

8 Temperaturas mínimas e máximas de mai/94 a abr/95 26

9 Distribuição da precipitação pluvial de mai/95 a abr/96 26

10 Temperaturas mínimas e máximas de mai/95 a abr/96 26

11 Rendimentos acumulados relativos (\%) de trigo, safras 1992, 38 1993 e 1995.

12 Rendimentos relativos de trigo, safra 1992.

13 Rendimentos relativos de trigo, safra 1993.

14 Rendimentos relativos de trigo, safra 1995.

15 Rendimentos acumulados relativos (\%) de soja, safras 1992, 1994 e 1996.

16 Rendimentos relativos (\%)de soja, safra 1992.

17 Rendimentos relativos (\%) de soja, safra 1994.

18 Rendimentos relativos (\%) de soja, safra 1995.

19 Rendimentos acumulados relativos (\%) de milho, safras 199342 e 1994.

20 Rendimentos relativos de milho, safra 1993.

21 Rendimentos relativos de milho, 1995.

22 Vista da gleba experimental, com trigo danificado por geada 63 
23 Crotalária na fase de desenvolvimento ao lado de soja na 63 fase de maturidade

24 Parcela com plantas daninhas ao ao lado de parcelas com 63 crotalária

25 Parcela com crotalária, sem invasoras. 
1. Valores da análise química do solo, amostrado em 1991.

2. Valores percentuais de estabilidade dos agregados, 1991.

3. Calendário e disposição das sucessões de culturas dos 27 tratamentos

4. Rendimentos de grãos $\left(\mathrm{kg} \cdot \mathrm{ha}^{-1}\right)$ das culturas no período.

5. Rendimentos $\left(\mathrm{kg} \cdot \mathrm{ha}^{-1}\right)$ das culturas e resultados das análises 37 estatísticas...

6. Resultados das análises químicas do solo, de 1996 e 1991. 44

7. Resultados dos teores de P, K, Ca $+\mathrm{Mg}$ e M.O. em duas 45 profundidades

8. Distribuição dos agregados DMG $>2 \mathrm{~mm}$ sob três 48 profundiades - 1996.

9. Fracionamento da M.O. (g. $\left.\mathrm{kg}^{-1}\right)$ do solo na profundidade 49 de $0-3 \mathrm{~cm}$

10 Rendimento de matéria seca e altura da crotalária júncea no 50 período.

11 Densidades de plantas daninhas, na fase de pré-semeadura 51 de trigo/1993.

12 Densidades de plantas daninhas, na fase de pré-semeadura 52 de trigo/1994.

13 Receita líquida auferida, para as culturas de trigo, soja e 54 milho...

14 Níveis de $\mathrm{N}$ em cobertura em trigo e retorno financeiro por 55 unidade aplicada.

15 Total dos custos com controle de plantas daninhas e 57 valores...

16 Balanço econômico dos resultados acumulados-final do 57 período.

17 Eficiência energética (EE) por safra 
18 Eficiência cultural (EC) por safra

1. Custo de produção por hectare de trigo, safra 1991.

2. Custo de produção por hectare de trigo, safra 1992.

3 Custo de produção por hectare de trigo, safra 1993.

4 Custo de produção por hectare de trigo, safra 1994.

5 Custo de produção por hectare de trigo, safra 1995.

6 Custo de produção por hectare de soja, safra 1992.

7 Custo de produção por hectare de soja, safra 1993.

8 Custo de produção por hectare de soja, safra 1994.

9 Custo de produção por hectare de soja, safra 1995.

10 Custo de produção por hectare de soja, safra 1996.

11 Custo de produção por hectare de milho, safra 1993.

12 Custo de produção por hectare de milho, safra 1995.

13 Ocorrência de geadas em épocas críticas para trigo, no Oeste 84 do PR.

14 Coeficiente técnico e balanço energético na produção de 85 trigo - 1991.

15 Coeficiente técnico e balanço energético na produção de 86 trigo - 1992.

16 Coeficiente técnico e balanço energético na produção de 87 trigo - 1993.

17 Coeficiente técnico e balanço energético na produção de 88 trigo - 1994.

18 Coeficiente técnico e balanço energético na produção de 89 trigo - 1995.

19 Coeficiente técnico e balanço energético na produção de soja 90 - 1992.

20 Coeficiente técnico e balanço energético na produção de soja 91 - 1993. 
21 Coeficiente técnico e balanço energético na produção de soja 92 - 1994.

22 Coeficiente técnico e balanço energético na produção de soja 92 - 1995.

23 Coeficiente técnico e balanço energético na produção de soja 93 - 1996.

24 Coeficiente técnico e balanço energético na produção de 94 milho- 1993.

25 Coeficiente técnico e balanço energético na produção de 95 milho- 1995. 


\title{
EFEITO DA Crotalaria juncea Linn. NA EFICIÊNCIA AGRONÔMICA, ECONÔMICA E ENERGÉTICA DE CULTURAS EM SUCESSÃO SOB PLANTIO DIRETO
}

\author{
Autor: Elir de Oliveira \\ Orientador: Prof. Dr. Antonio Luiz Fancelli
}

\section{RESUMO}

Estudou-se o efeito da crotalária júncea (Crotalaria juncea Linn.) na sucessão de culturas, como adubação verde de entressafra em sistema de sucessão de culturas, durante dez safras, no período de maio/1991 a março/1996. Para tanto, foram avaliados os rendimentos de grãos das culturas, as análises química e física do solo, população de plantas daninhas em dois períodos, além do balanço econômico e energético dos sistemas estudados.

O experimento foi instalado em um solo classificado como Latossolo Roxo eutrófico, na Estação Experimental do IAPAR, no município de Palotina, PR.

O delineamento experimental adotado foi o de blocos casualizados, com quatro repetições, constituído por seis tratamentos, compostos das seguintes sucessões: $\mathbf{T}_{1}$. Milho-crotalária-trigo-soja, com $30 \mathrm{~kg} \cdot \mathrm{ha}^{-1}$ de $\mathrm{N}$ em cobertura no trigo. $\mathbf{T}_{2}$. Milho-crotalária-trigo-soja, com $60 \mathrm{~kg} \cdot \mathrm{ha}^{-1}$ de $\mathrm{N}$ em cobertura no trigo. $\mathbf{T}_{3}$.Milho-trigo-soja, com 30 kg.ha ${ }^{-1}$ de $\mathrm{N}$ em cobertura no trigo. $\mathbf{T}_{4}$. Milho-crotalária-trigo-soja, sem cobertura no trigo. $\mathbf{T}_{5}$. Milho-trigo-soja, com $60 \mathrm{~kg} \mathrm{ha}^{-1}$ de $\mathrm{N}$ em cobertura no trigo. $\mathbf{T}_{6}$. Trigo-soja, com $30 \mathrm{~kg} \cdot \mathrm{ha}^{-1}$ de $\mathrm{N}$ em cobertura no trigo. 
A semeadura do adubo verde foi realizada após cada safra de milho, em cuja biomassa manejada com rolo-faca, foi realizada a semeadura do trigo. O preparo do solo consistiu nas operações de escarificação e gradagem nas duas primeiras safras de verão e semeadura direta nas safras de inverno, sendo que a partir do terceiro ano, todas semeaduras foram realizadas sob sistema de plantio direto.

Pela análise dos resultados obtidos, detectou-se diferença estatística nos rendimentos de grãos de soja, milho e trigo em, pelo menos, uma das safras de cada espécie. Ainda, foi observado que a crotalária não atendeu as necessidades de nitrogênio da cultura do trigo que a sucedeu.

Entretanto, na safra de inverno 1995, com a ocorrência de severo défice hídrico, o tratamento com crotalária sem $\mathrm{N}$ em trigo foi, estatisticamente, superior a todos os demais.

A avaliação dos resultados da análise química do solo, realizada no final do período experimental, foi detectado diferença estatística apenas para $\mathrm{K}$, apesar dos teores médios de $\mathrm{P}$, em todos os tratamentos, terem sido superiores aos amostrados na fase inicial do ensaio. A análise física do solo, apresentou significância para estabilidade dos agregados apenas na profundidade de $0-5 \mathrm{~cm}$, apesar de ter sido detectado o aumento do teor de matéria orgânica ao longo dos anos.

O levantamento de população de plantas daninhas em dois períodos evidenciou diferenças significativas, bem como o aumento da eficiência no manejo integrado de plantas daninhas, permitindo a redução do uso de herbicidas.

A análise do balanço energético, constituído pela Eficiência Energética (EE) e Eficiência Cultural (EC) evidenciou diferenças estatísticas favoráveis para o tratamento $\mathbf{T}_{\mathbf{4}}$. Milho-crotalária-trigo-soja, sem cobertura de $\mathrm{N}$ no trigo. Contudo, todos os tratamentos com adubação verde apresentaram tendência de superioridade no balanço energético, demonstrando que a utilização da crotalária contribuiu para a melhor eficiência energética dos sistemas agrícolas estudados. 
Com relação ao balanço econômico, sua análise não mostrou diferenças significativas entre as receitas líquidas acumuladas no final do período, sendo que os tratamentos com crotalária acumularam receita líquida média de $R \$ 2.299,00 . \mathrm{ha}^{-1}$ enquanto que os tratamentos $T_{3}$ e $T_{5}$ diferenciados apenas pela ausência da crotalária - apresentaram receita líquida média $\mathrm{R} \$ 1.948,00 . \mathrm{ha}^{-1}$. Da mesma forma, a média das relações benefício/custo dos tratamentos com crotalária foram superiores comparado com a média das relações dos tratamentos sem o adubo verde.

Considerando sustentabilidade do agroecossistema, os sistemas $\mathrm{T}_{1}$ e $\mathrm{T}_{4}$, sucessões com crotalária, com 30 e $0 \mathrm{~kg} \cdot \mathrm{ha}^{-1}$ de $\mathrm{N}$ em cobertura no trigo, demonstraram serem mais adequados sob a maioria dos parâmetros analisados. 


\title{
EFFECT OF Crotalaria juncea Linn. IN THE AGRONOMIC, ECONOMIC, AND ENERGETIC EFFICIENCY OF SUCCESSION CROPS UNDER NO- TILLAGE
}

\author{
Author: Elir de Oliveira \\ Major Adviser: Prof. Dr. Antonio Luiz Fancelli
}

SUMMARY

The effect of crotalaria juncea (Crotalaria juncea Linn.) in the crop succession, as green manure cultivated in between cash crops of the crop succession systems, during 10 agriculture crops, in the period may/1991 to mar/1996 was studied. For these, the crops grain yield, the chemical and physical soil analysis, the weed population in two periods, besides the economic and energetic balance of the studied systems were evaluated.

The experiment was established in a soil classified as Tipic Haplorthox (US Soil Taxonomy) at the IAPAR's Experiment Station of Palotina, PR.

The Randomized Block Design, with four replications of the six treatments of the following successions were adopted: $\mathbf{T}_{\mathbf{1}}$. Corncrotalaria-wheat-soybeans, with $30 \mathrm{~kg} \cdot \mathrm{ha}^{-1}$ of $\mathrm{N}$ as dressing on the wheat. $\mathbf{T}_{2}$. Corn-crotalaria-wheat-soybeans, with $60 \mathrm{~kg} \cdot \mathrm{ha}^{-1}$ of $\mathrm{N}$ as dressing on the wheat. $\mathbf{T}_{\mathbf{3}}$. Corn-wheat-soybeans, with $30 \mathrm{~kg} \cdot \mathrm{ha}^{-1}$ of $\mathrm{N}$ as dressing on the wheat. $\mathbf{T}_{\mathbf{4}}$. Corn-crotalaria-wheat-soybeans, without dressing on the wheat. $\mathbf{T}_{5}$. Corn-wheat-soybeans, with $60 \mathrm{~kg} \mathrm{ha}^{-1}$ of $\mathrm{N}$ as dressing on the wheat. $\mathbf{T}_{\mathbf{6}}$. Wheat-soybeans, with $30 \mathrm{~kg} \cdot \mathrm{ha}^{-1}$ of $\mathrm{N}$ as dressing on the wheat. 
The sowing of green manure was made after each corn crop, in which the biomass was managed with the knife-roll and the wheat sowing was made. The soil preparation consisted of the operations escarification and harrowing in the two first summer crops and zero till in the winter crops, with all sowings being under the zero till system begining in the third year.

By the obtained results analysis, is was detected statistical differences in the grain yield of soybeans, corn, and wheat, in at least one of the crops of each species. It was observed that crotalaria did not funished the nitrogen needed by the succeding wheat crop.

However, in the 1995 winter season, with the severe water deficit occurrence, the treatment with crotalaria without $\mathrm{N}$, was statistically superior to all others.

With the evaluation of chemical soil analysis, performed at the end of the experimental period, it was detected significative difference only for $\mathrm{K}$, although the average levels of $\mathrm{P}$, were superior to the samples taken at the initial phase of the experiment. The physical soil analysis, showed significance for aggregate stability only at the $0-5 \mathrm{~cm}$ deph, besides the organic matter level being increased along the years.

The weed population evaluation in two periods showed significative differences, as well as an increase in the efficiency of integrated weed management. allowing a reduction in the use of herbicides.

The energetic balance analysis, constituted by the Energetic Efficiency (EE), and Cultural Efficiency (CE) has shown significant differences favorable to the treatment $\mathbf{T}_{\mathbf{4}}$. Corn-crotalaria-wheat-soybeans, without $\mathrm{N}$ dressing in the wheat. However, all the green manure treatments presented superior tendency in the energetic balance, demonstrating that the utilization of crotalaria contributed to a better energetic efficiency of the agricultural systems studied.

In relation to the economic balance, the analysis did not show significative differences among the net income accumulated at the end of the period, in which the treatments with crotalaria had a average net 
income of $\mathrm{R} \$ 2.299,00 . \mathrm{ha}^{-1}$, while the treatments $T_{3}$ and $T_{5}$ - differentiated only by the absence of crotalaria presented average net income of $\mathrm{R} \$ 1.948,00 . \mathrm{ha}^{-1}$. In the same way, the ratio mean benefit/cost of treatments with crotalaria was upper compared to treatments without the green manure.

Considering the agrosystem sustentability, the system $T_{1}$ and $\mathrm{T}_{4}$, sucession with crotalaria, with 30 and $0 \mathrm{~kg} \mathrm{ha}^{-1}$ of $\mathrm{N}$ as dressing fertilization in wheat, demonstrated to be the more adequated in all analysed parameters. 


\section{INTRODUÇÃO}

A região Oeste do Estado do Paraná apresenta grande percentagem de solos de alta aptidão agrícola, tradicionalmente utilizados com as culturas de soja, milho e trigo, essa última em menor escala, em consequência da atual política agrícola adotada pelo governo nos últimos anos.

O sistema de produção predominante nas últimas décadas tem sido fundamentado na monocultura de soja $\mathrm{e}$ trigo. Atualmente, nas regiões situadas abaixo de $500 \mathrm{~m}$ de altitude, predomina o sistema de exploração agrícola composto apenas por culturas de verão, principalmente soja e milho. A lavoura principal é semeada no período de setembro a outubro e a lavoura secundária, denominada de "safrinha", é semeada no período de fevereiro a abril.

Assim, o uso intensivo do solo em sistemas de monoculturas e o emprego de grades aradoras para seu preparo, associado ao sistema "safrinha", tem se constituído em entrave à adoção de práticas de manejo adequado do solo, tais como rotação de culturas, adubação verde e plantio direto.

No sistema de produção vigente, é pouco comum a adoção de práticas de rotação de culturas, previamente planejadas. Provavelmente, isso deve-se à falta de opções de espécies econômicas e pela resistência dos produtores para incorporação ao sistema de culturas não tradicionais, as quais poderiam concorrer para o aumento da taxa de risco do empreendimento. Neste contexto, o emprego de adubação verde cujos benefícios são amplamente reconhecidos quanto a manutenção da fertilidade dos solos e controle de plantas daninhas - tem sido ainda pouco 
adotado pelos produtores, principalmente pela não visualização de retorno imediato.

Ainda, a competição por área para exploração através das culturas de verão, associado a baixa lucrativa da atividade agrícola, tem contribuído para limitação da prática de adubação verde de verão.

Nas regiões tropicais, a não melhoria do solo e o emprego constante do preparo mecanizado, principalmente em latossolos com elevados teores de argila, leva à insustentabilidade da agricultura ao longo dos anos.

Assim, o sistema de plantio direto, com rotação/sucessão de culturas e adubação verde, incluindo a presença de cobertura morta na superfície do solo, destaca-se como prática adequada para os solos intensamente utilizados. Entretanto, apesar da tentativa de adoção do sistema por muitos produtores, parte deles não obtiveram o sucesso esperado. Pois, apenas a aquisição de semeadora específica foi considerada como único pré-requisito para a adoção do sistema, relegando outros ítens fundamentais a segundo plano.

Atualmente, mostra-se premente a busca de sistemas de produção capazes de recuperar a fertilidade do solo. Dentre eles, o cultivo de leguminosas como cobertura do solo no outono-inverno tem-se mostrado favorável, tanto na obtenção de renda extra na entressafra, como nos benefícios às culturas subsequentes.

Todavia, para superação dos entraves relativos à adoção da prática da adubação verde, há a necessidade de mais estudos sobre sistemas de produção com espécies de rápido crescimento, boa produtora de fitomassa, bem como de outras características. Nas regiões onde o solo é explorado intensivamente, os adubos verdes terão espaços assegurados quando apresentarem características para semeadura na época de entressafra das culturas econômicas.

Neste contexto, a Crotalaria juncea Linn., além da acentuada capacidade de fixação simbiótica do $\mathrm{N}$-atmosférico e controle de nematóides, é considerada com um adubo verde apresentando excelente 
capacidade de produção de fitomassa, mesmo durante curto período vegetativo, sendo possível sua introdução como espécie de entressafra.

Dessa forma, o presente trabalho objetivou estudar o efeito da crotalária júncea como adubo verde de entressafra, introduzido em sistemas dinâmicos de produção, procedendo a avaliação agronômica, econômica e energética, além da determinação da relação beneficio/custo, com vistas a sustentabilidade do agroecossistema. 


\section{REVISÃO DE LITERATURA}

\subsection{Características edafoclimáticas da região}

A região Oeste do Paraná está localizada entre os paralelos $24^{\circ}$ e $25^{\circ}$ Sul e meridianos $52^{\circ} 30^{\prime}$ e $54^{\circ} 30^{\prime}$ Oeste de Greenwich. A altitude varia de 160 a $800 \mathrm{~m}$ e as precipitações de 1400 a $1900 \mathrm{~mm}$. As temperaturas médias oscilam entre $17^{\circ} \mathrm{C}$ a $22^{\circ} \mathrm{C}$, sendo que a média mínima está entre $15^{\circ} \mathrm{C}$ e $20^{\circ} \mathrm{C}$ e a máxima média entre $25^{\circ} \mathrm{C}$ e $35^{\circ} \mathrm{C}$. Pelo sistema de classificação de Koppen, baseado na temperatura e pluviosidade, o tipo climático da região é classificado como Cfa (IAPAR, 1994). Os solos predominantes na região pertencem à Classe de Aptidão 1, dentro do nível C, conforme método de Ramalho Filho et al.(1978).

Nas áreas onde se pratica agricultura intensivamente mecanizada predominam os solos classificados como Latossolo Roxo eutróficos e distróficos, Latossolo Vermelho textura argilosa e Terra Roxa estruturada. Esses solos apresentam classe estrutural argila pesada e, quando úmidos evidenciam alto grau de plasticidade e pegajosidade (EMBRAPA, 1984). Segundo Kemper \& Vieira (1979), solos com essas características apresentam sérias dificuldades para a mecanização, principalmente por sofrerem deformação de sua estrutura quando trabalhados com graus de umidade acima do ideal, em função aumento da densidade global e da redução da porosidade, permeabilidade e infiltração de água.

Dados coletados e registrados oficialmente na Estação Agrometeorológica do IAPAR, no município de Palotina-PR, evidenciaram temperaturas de até $60^{\circ} \mathrm{C}$ a $2 \mathrm{~cm}$ de profundidade em solo sem cobertura morta, contra $29,9^{\circ} \mathrm{C}$ em solo totalmente coberto por resíduos vegetais. 
Salientando a importância da relação entre a temperatura e a cobertura do solo, Smith (1982), relata que, dentro de certos limites, a atividade microbiológica aumenta 2,5 vezes a cada aumento de $10^{\circ} \mathrm{C}$ na temperatura do solo. $O$ índice de atividade microbiológica no solo é inversamente proporcional à variação na temperatura do solo, sendo que no sistema plantio direto essa variação é menor que a do plantio convencional. Trabalho de Biederbeck \& Campbell (1971) mostrou que a variação de temperatura durante 19 dias, de 3 a $14^{\circ} \mathrm{C}$, ocasionou a redução da população de fungos, bactérias e actinomicetos. Resultados opostos foram obtidos quando a temperatura se manteve estável a $28^{\circ} \mathrm{C}$, o mesmo ocorrendo com temperatura estável a $8,5^{\circ} \mathrm{C}$.

\subsection{Práticas tradicionais de manejo de solo}

As práticas de manejo de solo, tradicionalmente adotadas nas áreas de soja e trigo, têm provocado severa erosão laminar nas regiões subtropicais brasileiras. O excessivo preparo do solo através do uso de grades aradoras ainda é prática comum, tendo como resultado uma intensa perturbação da camada arável $(0-10 \mathrm{~cm})$ do solo. Esse procedimento contribui para a destruição da matéria orgânica, redução da taxa infiltração de água e pela formação de camada em subsuperfície (entre $10-15 \mathrm{~cm}$ de profundidade), denominada de "pé-de-grade", o que resulta em acentuada erosão laminar e condições adversas para a penetração e desenvolvimento de raízes (Muzilli, 1984).

Ainda, a situação é agravada pela adoção do sistema tradicional de implantação de culturas, predominantes até a cinco anos passados, baseado na sucessão soja-trigo, o que tem ocasionado o balanço negativo de material orgânico naquele agroecossistema.

Nos últimos cinco anos, com o desestímulo à cultura do trigo, simultaneamente à queda do monopólio estatal da compra do referido produto e ausência de outra opção econômica para a época de outono/inverno, o sistema de produção tradicional, composto pelo binômio 
soja-trigo, cedeu espaço ao sistema conhecido como "safrinha". Assim, a expressão "safrinha" pode ser definida como a segunda safra de verão no mesmo ano agrícola, semeada após a época ideal recomendada para a espécie. Com a expansão do sistema "milho-safrinha" ou "soja-safrinha", vários problemas de ordem fitossanitária e de manejo de solo têm-se agravado. Bianco (1991) cita que essa exploração trouxe benefícios para os insetos-pragas de milho, vistos que as com as semeaduras tardias se estendendo até $\mathrm{o}$ período de março, propiciou $\mathrm{o}$ aumento da disponibilidade de alimentos e a ampliação do número de gerações e das populações de pragas. Em semeaduras de milho sobre restos de cultura de milho recém-colhido, ou soja após soja, os problemas sanitários podem atingir níveis críticos, inviabilizando agronomicamente o sistema de produção adotado.

O sistema de exploração do solo vigente tem provocado seu empobrecimento físico, químico e biológico, causado por práticas inadequadas que, associado às chuvas de alta intensidade, potencializam-se para causar danos ao meio-ambiente (VIEIRA, 1994). O sistema "safrinha", de modo geral, tem contribuído para isto, pois impede o planejamento da propriedade agrícola à médio e longo prazo; induz ao uso de grades pesadas, por permitir o início da próxima semeadura na maior brevidade possível; aumenta o número de operações de gradagens superficiais no período de inverno/primavera e/ou permite o aumento da população de plantas daninhas e bancos de sementes nesse período, por falta de cobertura vegetal do solo.

\subsection{Sistema de plantio direto}

Há muito tempo, o homem tem utilizado a prática de revolvimento do solo para efetuar a semeadura, principalmente com a intuito afrouxar o solo, eliminar as plantas indesejáveis e providenciar um local adequado onde as sementes são depositadas. Diante das alarmantes perdas de solo por erosão em todo mundo e com o advento dos herbicidas, 
tornou-se possível a implantação de culturas, forma sucessiva, sem o revolvimento do solo. Segundo Lal (1989), esse sistema de semeadura, denominado de plantio direto ou plantio de conservação, é um componente integral da agricultura sustentável.

Estima-se que o Brasil possui cerca de 2 milhões de hectares explorados por culturais anuais definitivamente sob o sistema de plantio direto, perfazendo $3,6 \%$ da área cultivada com as principais culturas. Ainda, anualmente tem sido incorporados ao sistema de plantio direto cerca de 300 mil hectares por ano, conforme relatado por Gentil (1995).

Nas regiões de agricultura intensivamente mecanizada, as práticas de manejo de solo necessitam de racionalização e adequação. Segundo Muzilli (1984), as perdas de solo por erosão podem ser reduzidas de $70 \%$ a $90 \%$ pelo preparo de solo com aração e duas gradagens ou pelo sistema de plantio direto, ou mesmo pela prática de escarificação e gradagens niveladoras, quando comparados ao uso contínuo de grade aradora.

O sistema de plantio direto, possibilita maior proteção do solo pela presença de resíduos vegetais na superfície; maior retenção de água no solo; menor perda por evaporação; menor variação da temperatura do solo; menor disseminação de nematóides; menor perda de rendimentos de grãos por períodos de estiagens; redução de despesas com preparo do solo, bem como permite a semeadura das culturas em épocas mais adequadas (Kuipers, 1980), (Vieira, 1981), (Wiles \& Yamaoka, 1981), (Muzilli, 1984), (Phillips \& Phillips, 1984), (Almeida \& Rodrigues, 1985), (Griffith et al., 1986), (Fancelli \& Favarin, 1987), (Bolaños, 1989) e (Derpsch et al., 1991). Segundo Phillips (1986), a época ideal de semeadura é fator determinante para obtenção de rendimento máximo de grãos e afirma que nos 17 estados produtores de milho, nos Estados Unidos, metade deles semeiam milho após a época ideal, e que em função desse fato, a produção diminui 6-7\% para cada semana de atraso a partir de semeaduras realizadas após 10 de maio.

Conforme Vieira (1994), as chuvas são o maior agente final de erosão do solo no Estado do Paraná. Onde predomina o clima Cfa ( regiões 
Norte, Oeste e Noroeste), o periodo de maior concentração da precipitação pluvial ocorre nos meses de outubro a março. Além da distribuição irregular, os valores de erosividade são altos, atingindo de 7.000 a 12.000 MJ (megajoule). Esses dados evidenciam a necessidade de manutenção da cobertura do solo, de forma permanente, o que pode ser obtido com a adoção do sistema de plantio direto. Vieira (1979) obteve $50 \%$ de redução das perdas de solo por erosão apenas com adição de 3,4 t.ha ${ }^{-1}$ de palha de trigo na superfície do solo, comparado com a perda de solo em áreas onde os restos de culturas foram queimados.

Dados disponíveis na literatura confirmam que o problema de erosão, perda de solo e assoreamento dos mananciais é maior nas regiões de clima tropical do que nas de clima temperado. Jenkinson \& Ayanaba (1977) afirmam que, nas regiões tropicais e subtropicais, devido as condições de temperatura e umidade, o processo de decomposição e mineralização do material orgânico adicionado ao solo ocorre de forma mais acelerada, comparado com as regiões de clima temperado.

Kemper (1995) descreve que a compactação do solo a 10-20 $\mathrm{cm}$ da superfície aumenta apenas nos primeiros anos de implantação do sistema de plantio direto. Entretanto, a ausência do revolvimento do solo e a presença de resíduos das culturas na superfície, resulta no desenvolvimento de maior população de oligoquetos e outros componentes da mesofauna que escavam o solo para obtenção de alimentos. Segundo o mesmo autor, essas micro-escavações têm permitido rápida infiltração da água em muitos solos e que a enxurrada é praticamente eliminada em áreas onde o preparo convencional poderia acarretar na perda de 10 a $30 \%$ da precipitação, mediante escorrimento superficial.

A principal vantagem do sistema de plantio direto é a redução de perdas de solo por erosão hídrica. Conforme dados do IAPAR (1977, 1978 e 1979), as perdas de solo por erosão no Estado do Paraná, em solos argilosos, explorados com soja e trigo, atingem os níveis de 114,38 e 11 t.ha ${ }^{-1}$, respectivamente, para os sistemas de preparo de solo com grade pesada + duas grades niveladoras, preparo convencional e plantio direto. Freitas \& Castro (1980), por estimativas baseadas nos levantamentos do 
Serviço Nacional de Conservação de Solo, da EMBRAPA, encontraram perdas para o Paraná de 1,8 bilhões de toneladas de solo por ano, ou seja, perda média de 72 t.ha $^{-1}$, anualmente. Derpsch et al. (1991) citam que em áreas de maior declividade, com solos mal manejados, sem conservação e submetidas a alta precipitação, as perdas de solo podem atingir 700 t.ha ${ }^{1}$.ano ${ }^{-1}$. Griffith et al., (1986) assinala que perda aceitável de solo por

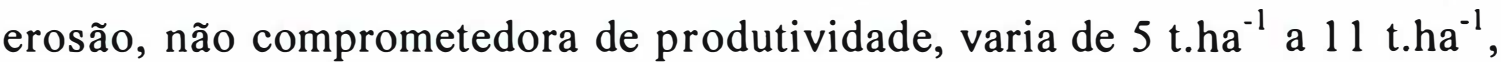
de solo de perfil mais raso a mais profundo, respectivamente. Mondardo \& Biscaia (1981) salientam que a perda tolerada de solo para o Estado do Paraná é de 10 a 15 t.ha $^{-1}$ por ano. Lombardi \& Bertoni (1985) citam perdas de solo aceitáveis de 12 t.ha $^{-1}$. ano para Latossolo Roxo e 13,4 t.ha ${ }^{1}$.ano $^{-1}$ para Terra Roxa estruturada. Dentro de um limite de perda aceitável, Hall et al. (1985) estimaram que em 50 anos seria removido 2,5 $\mathrm{cm}$ de solo e em 400 anos, os primeiros $20 \mathrm{~cm}$ do solo estariam destruídos. Sobretudo, ponderam que a formação do solo é o resultado de uma complexa interação entre vegetação e derivados, condicionado pelo clima, atuando na topografia sobre o tempo. Sendo esses parâmetros variáveis independentes, a taxa de formação do solo é extremamente variável. Dessa forma, conhecer a taxa de rejuvenescimento ou formação do solo é necessário para admitir um índice de erosão aceitável.

$\mathrm{Na}$ agricultura moderna, que busca sua sustentabilidade, além da conservação do solo, há preocupação com o balanço energético dos sistemas agrícolas. Conforme relata Pimentel (1980), os rendimentos na agricultura dos Estados Unidos tiveram um rápido aumento a partir da década de 40, como resultado de novos cultivares; do melhoramento da tecnologia de produção vegetal e animal. Sendo que essa inclui, principalmente, o uso de fertilizantes, pesticidas, mecanização pesada e irrigação; todos altamente dependentes de energia fóssil ou com alto custo energético para produção.

Por outro lado, Heady (1984) relata, que, ainda nos Estados Unidos, $25 \%$ da energia utilizada na agricultura é proveniente de fertilizantes e pesticidas, equivalendo a quase duas e meia vezes a energia usada em maquinaria e três vezes a utilizada em irrigação. Dessa forma, 
segundo o autor, poderá haver redução do uso de insumos e tecnologias de alto custo energético, por perda de competividade, com o aumento dos preços da energia por volta do ano 2.000 .

\subsection{Rotação de culturas}

A adoção do sistema de plantio direto requer vários prérequisitos, sendo a rotação ou sucessão de culturas previamente planejada, o mais importante deles. Para Geisler $(1980)^{1}$, citado por Derspch et al.(1991), rotação de culturas é a alternância regular e ordenada de diferentes espécies vegetais, em sequência temporal numa determinada área. Derspch et al. (1991) definem a sucessão de culturas como a alternância pré-estabelecida de culturas, dentro do mesmo ano agrícola

Miyasaka et al. (1983) destacam os principais objetivos da rotação de culturas, como sendo: melhor distribuição das culturas na propriedade; economia de trabalho; controle de plantas daninhas, pragas e doenças; incorporação e ciclagem do nitrogênio; redução das perdas por erosão e aumento das produções das culturas. Os mesmos autores citam que Neves (1948) demonstrou o aumento de rendimentos pela rotação de culturas. Vários outros trabalhos conduzidos no Estado do Paraná demonstram aumento de rendimentos das culturas subsequentes, quando o sistema de exploração passou de monocultivo para rotação de culturas. Muzilli et al. (1983) obtiveram acréscimo de 0,47 t.ha $^{-1}$ no rendimento de grãos de milho em rotação com soja, comparado com o seu rendimento em monocultura. Muzilli (1981) obteve acréscimo de 0,33 t.ha ${ }^{-1}$ de soja com a rotação das culturas de soja, trigo e milho em comparação com o sistema de sucessão de soja e trigo. No Estado de São Paulo, Gallo et al.(1981) observaram aumento de $0,47 \mathrm{t}_{\text {. ha }}{ }^{-1}$ no rendimento de milho após soja, em comparação com a monocultura de milho.

\footnotetext{
' GEISLER, G. Pflanzenbau, biologische grundlagen und technik der pflanze: produktion. Berlin:
} P. Parey, 1980. 474 p. 
Tisdale et al. (1985) relatam que, em geral, em condição de alta produtividade, os resultados demonstram que os rendimentos de milho em sistema de monocultura tem sido $15 \%$ inferior, comparados aos rendimentos de grãos dessa gramínea dentro de sistemas de rotações de culturas. Da mesma forma, Mascarenhas et al.(1986), pesquisando a resposta de milho, submetido a cinco níveis de $\mathrm{N}$, após diversos anos do semeadura de soja, obtiveram resultados até a quatro e cinco anos da safra de soja. Resultados semelhantes, os mesmos autores obtiveram com trigo e arroz, demonstrando a influência da soja sobre essas gramíneas.

De acordo com Franzluebbers et al. (1995), o declínio nos rendimentos dos cereais, desenvolvidos em sistemas de monoculturas, podem ser amenizados com estratégias de manejo, que inclui rotação de culturas, otimização do preparo do solo, uso racional de fertilizante e manutenção da matéria orgânica do solo. Os mesmos autores, em experimento de longa duração, comparando a monocultura de sorgo-trigo, obtiveram no esquema de rotação com sorgo-trigo-soja, maior eficiência no uso da terra, com igual ou menor demanda de nitrogênio e maior produção de restos culturais. Ainda, o conteúdo de nitrogênio apresentou melhor qualidade pela inclusão de soja no programa de rotação, permitindo menores perdas por lixiviação através da ciclagem do elemento entre a cultura e a matéria orgânica do solo. Conforme Mengel \& Kirkby (1987), as plantas possuem capacidades específicas de retiradas de nutrientes do solo e exploram diferentes profundidades do mesmo, o que faz com que a rotação de culturas propicie a ciclagens de nutrientes de forma efetiva.

Nos países de clima temperado, onde se desenvolvem atividades agrícolas com uso intensivo de insumos, um dos grandes problemas ambientais que tem ocorrido é a poluição dos mananciais de águas subterrâneas pelo $\mathrm{N}-\mathrm{NO}_{3}^{-}$lixiviado, comprometendo por demais a sua potabilidade. A possibilidade do retardamento das perdas por lixiviação através da imobilização de nutrientes pelos microorganismos do solo e pela absorção das plantas, principalmente no verão, segundo Smith (1982), pode permitir um equilíbrio harmônico. Entretanto, no inverno, 
durante período de baixa atividade microbiológica e baixa imobilização, a possibilidade de ciclagem de nutrientes com plantas de alta absorção é maior. Smith (1982) ainda relata que $70 \%$ do N presente no solo está imobilizado pela microflora do solo, demonstrando então sua contribuição para evitar perdas por lixiviação, pela sua conservação natural.

Segundo Chichester (1977), a excessiva aplicação de esterco ou fertilizante nitrogenado pode resultar em altos níveis de nitratos que, permanecendo no solo após a colheita, podem lixiviar até as águas subterrâneas, vindo a contaminá-las. Vários outros pesquisadores tem direcionado seus trabalhos para melhor compreensão do fenômeno, entre os quais, Jabro et al. (1995), Owens et al. (1995), Guillard et al. (1995a), Guillard et al. (1995b), Sims et al. (1995), Kelley (1995). Nesse sentido, Guillard et al. (1995a) relataram que em Connecticut, nos Estados Unidos da América, existe regulamento recomendando o uso de plantas de cobertura como azevém no inverno, após colheita da cultura principal, visando maior retenção de N. Esses autores obtiveram a recuperação de $24 \%$ do $\mathrm{NO}_{3}{ }^{-}-\mathrm{N}$ acumulado até $60 \mathrm{~cm}$ de profundidade no solo, após colheita de milho, com semeadura de azevém no inverno. Entretanto, encontraram a menor perda de $\mathrm{NO}_{3}{ }^{-} \mathrm{N}$, em níveis acima de $224 \mathrm{~kg} \cdot \mathrm{ha}^{-1}$ de $\mathrm{N}$ em milho, através do cultivo de aveia (Avena sativa L.) seguido por tyfon [Brassica rapa L. X B. pekinensis (Lour.) Rupr.]. Shipley et al. (1992), em outra localidade, conseguiu a recuperação de $45 \%$ de $\mathrm{NO}_{3}{ }^{-}-\mathrm{N}$, trabalhando com azevém no inverno. Também estudando a perda de nitrogênio no solo, empregando u réia supergranulada, em dois tipos de solos, Singh \& Singh (1988), constataram perdas por lixiviação de uréia-N, $\mathrm{NH}^{+}-\mathrm{N}$ e $\mathrm{NO}_{3}{ }^{-} \mathrm{N}$, da ordem de $3,3,24,5$ e $2,4 \%$, respectivamente, para solos argilosos e 5,4, 30,7 e 3,0\% para solos arenosos. Os autores ainda obtiveram outros dados revelando que, dentro do período de 49 dias após o uso, 49 e $32 \%$ do $\mathrm{N}$ aplicado foram recuperados por plantas de arroz no solo argiloso e arenoso, respectivamente.

Em nossas condições, pela forma e doses em que o $\mathrm{N}$ vem sendo aplicado nas culturas de cereais, a perda desse elemento, por via gasosa, parece ter maior importância que a perda por lixiviação. Exceto, 
com a ocorrência de chuvas torrenciais após aplicação, quando as perdas por lixiviação passa a ter importância aumentada.

A rotação de culturas acarreta, dentre outras vantagens já citadas, benefícios ao condicionamento físico do solo. Trabalhos realizados por Campos et al. (1995) e Albuquerque et al. (1995), visando avaliar o impacto da rotação de culturas e de sistemas de manejo do solo sobre a estabilidade dos agregados e condutividade hidráulica, encontraram os melhores resultados em sistema de rotação, quando comparada à sucessão trigo/soja. Ainda, Harris et al. (1966) relatam que o método mais eficiente de estruturação do solo é obtida com a consorciação de gramíneas (com sistema radicular abundante e em constante renovação) com leguminosas (que fixam nitrogênio, intensificando a atividade microbiológica do solo).

Além da importância dos resíduos de leguminosas como fornecedor de N, segundo Hargrove (1986), os mesmos podem contribuir para diminuição da acidez do solo, para a redistribuição de $\mathrm{K}^{+}$, bem como para a diminuição da relação $\mathrm{C} / \mathrm{N}$ da matéria orgânica do solo. Primavesi (1982), por sua vez, ressalta a importância dos resíduos das gramíneas para a melhoria do solo, pelo seu. maior conteúdo de lignina e, consequentemente, maior formação de ácido carboxílico, originando maior teor de ácido húmico no substrato, o que, segundo Fassbender \& Bornemisza (1994), favorece a estruturação e a estabilidade dos agregados do solo.

A composição química dos resíduos vegetais tem um importante papel para determinação da sua taxa de decomposição. Schomberg et al. (1994) relatam que a degradação desses resíduos libera $55 \%$ a $70 \%$ de $\mathrm{C}$ para a atmosfera na forma de $\mathrm{CO}_{2}$, sendo 5 a $15 \%$ incorporado como biomassa microbial e o restante (15 a 40\%), é particularmente estabilizado no solo como húmus. Em geral, resíduos com concentração menor que $1,5-1,8 \%$ de $\mathrm{N}$ ou relação $\mathrm{C} / \mathrm{N}$ maior que 30 é considerado resíduo imobilizador de $\mathrm{N}$ inorgânico (Schomberg et al.,1994 e Smith, 1982). 
Do ponto de vista fitopatológico, o sistema plantio direto é dependente do uso de programas de rotação de culturas, principalmente por se fundamentar na permanência dos restos culturais sobre a superfície do solo, favorecendo o desenvolvimento de patógenos de hábitos necrotróficos. Yorinori et al.(1993), afirmam, porém, que a monocultura tem favorecido o surgimento de novas doenças e promovendo alguns patógenos de importância secundária para primária.

O trigo é uma das culturas mais sensíveis, a imensa gama de patógenos, em condições de monocultura no sistema de plantio direto e sob temperatura e umidade favoráveis. Igarashi (1981) e Mehta (1981) observaram maiores problemas de doenças foliares e radiculares em trigo sob plantio direto do que no sistema convencional. Dentro do sistema de plantio direto, Reis (1995) sugere esquemas de rotações de culturas que permitam a completa decomposição e mineralização dos restos culturais que hospedam os patógenos necrotróficos, inviabilizando a sobrevivência desses para a próxima safra. Para a cultura do trigo, o controle de patógenos biotróficos como oídio (Erysiphae graminis) e ferrugens (Puccinia spp.), o referido autor recomenda a eliminação permanente de plantas espontâneas e plantas daninhas hospedeiras desses patógenos. Dessa forma, a rotação de trigo com leguminosas de inverno ameniza os proablemas fitossanitáriso da gramínea.

O controle de plantas daninhas têm sido um grande problema para a agricultura, principalmente nos trópicos, onde o diversidade de espécies é maior do que nas regiões de clima temperado. Segundo Almeida \& Rodrigues (1985), o sistema de plantio direto pode apresentar maior problema e maior custo no controle de plantas daninhas. Assim, avaliando a composição de custos com herbicidas Montoya (1984) observou valores de $9 \%, 14 \%$ e $2,3 \%$ para plantio convencional contra $21 \%, 23 \%$ e $5 \%$ para plantio direto, para as culturas de soja, milho e trigo, respectivamente. Entretanto, Fancelli \& Favarin (1987) e Montoya (1984) citam que os custos de produção do sistema de plantio direto tornam-se semelhantes aos custos do sistema convencional a partir do terceiro ou quarto ano de sua implantação. 
Com relação ao matocontrole, Fryrear \& Bilbro (1994) relatam que, dependendo da área, a rotação de cultura possibilita incluir componentes que permitem o controle mais efetivo de plantas daninhas e oferecem maior oportunidade para um seletivo controle químico. Contudo, Almeida \& Rodrigues (1985) propõem a adoção da prática de rotação de culturas, adubação verde e controle químico como manejo integrado de plantas daninhas dentro do sistema de plantio direto.

\subsection{Adubação verde}

Para Pieters (1927), adubação verde é a prática de enriquecimento do solo pela incorporação, ou não, de plantas apresentando material não decomposto, exceto resíduo de colheita, oriundo ou trazido de outro local. De forma semelhante, Kiehl (1959), citado por Miyasaka et al. (1983), define adubo verde como sendo a planta cultivada, ou não, com a finalidade precípua de enriquecer o solo com sua massa vegetal, produzida no local ou importada.

O uso de adubos verdes e outros adubos orgânicos contribuem para a melhoria do solo, mas, a longo prazo, seu efeito pode ser pequeno ou até diminuir o conteúdo de matéria orgânica original do solo, devido a aceleração da atividade microbiana (Smith, 1982).

Associado ao sistema de plantio direto e a rotação de culturas, a adubação verde é prática indispensável para o sucesso do sistema. Possue o benefício de aporte de nitrogênio e matéria orgânica ao solo, evita a lixiviação e cicla os nutrientes das camadas mais profundas do solo até a camada arável, solubiliza alguns nutrientes, então insolubilizados, favorece o manejo de plantas daninhas, incrementa a micro e mesofauna do solo, permite menor variação na temperatura e menor oscilação do grau de umidade do solo, melhora a taxa de infiltração de água, diminue a erosão e o estresse da planta por déficit hídrico (Pieters, 1927), (Derpsch et al.,1991), (Miyasaka et al.,1983), (Muzilli, 1986), (Phillips \& Phillips, 1986), (Carvalho \& Calegari, 1988), (Almeida, 1988), (Primavesi, 
1984). O estresse por défice hídrico ocorre, segundo Krieg (1993), quando a demanda transpirativa excede a capacidade do solo no suprimento de água à planta. Lembra ainda o autor que o mecanismo utilizado pelas plantas para minimizar as perdas de água é negativamente relacionada com a manutenção da produtividade.

As espécies recomendadas para adubação variam quanto a sua exigência em fertilidade e acidez do solo. Entretanto, a prática sistemática de adubação verde com materiais com relação $\mathrm{C} / \mathrm{N}$ mais elevada, poderá elevar temporariamente a acidez aparente do solo pela liberação de íons de hidrogênio. Da mesma forma, pelo aumento nos níveis de matéria orgânica, o poder tampão desse solo também será mais elevado. As leguminosas parecem diferir das não-leguminosas quanto aos efeitos residuais deixados no solo. Pieters (1927) cita que White (1916) $)^{2}$ estudou os requerimentos de calcário em solo onde foi adicionado matéria fresca e matéria seca de diversas espécies de leguminosas e de não-leguminosas. No final de três meses e de nove meses da sua incorporação, os solos que receberam leguminosas tiveram suas necessidades de calcário diminuídas de forma decrescente quanto ao tempo. Entretanto, nos tratamentos com as nãoleguminosas, em comparação ao solo que não recebeu adubo verde, as necessidades de calagens foram menores aos três meses e maiores aos nove após.

Em áreas de plantio direto, envolvendo rotação com gramíneas, tais como trigo e milho, a demanda por nitrogênio é $20 \%$ a $30 \%$ maior, se comparado com o sistema convencional (Phillips \& Young, 1973). Todavia, Phillips \& Phillips (1986) afirmam que a demanda de N pelas culturas no plantio direto e convencional não diferem entre si, salvo se os rendimentos entre elas forem muito diferenciados. É possível que a divergência nas afirmações deva-se mais às condições específicas em que os trabalhos foram realizados. Pois, sabe-se que fatores como temperatura, umidade, teor de matéria orgânica do solo, estágio de decomposição e

2 WHITE, J.W. Soil acidity: the relation of green manuring to its development. Pennsilvania Agriculture Experimental Station Annual Reporter, 1914-1915, p. 60-86, 1916. 
níveis de atividade do íon $\mathrm{H}^{+}$, equilíbrio da relação $\mathrm{C} / \mathrm{N}$ do solo, tempo de implantação do sistema de plantio direto e o tipo de rotação de culturas, são fatores determinantes dos níveis de demanda de $\mathrm{N}$ pelas culturas, bem como por sua perda por volatilização.

As perdas de nitrogênio por volatilização devem ser consideradas quando se usa o nitrogênio mineral, bem como a forma de aplicação e a profundidade de deposição dos grânulos do adubo. Segundo Hargrove (1988), além da atividade da urease ser influenciada pela temperatura, umidade e $\mathrm{pH}$ do solo, os resíduos culturais possuem alta atividade dessa enzima. Mclinnes et al. (1986), trabalhando em um solo franco-arenoso, determinou que a atividade da urease sobre a palha de trigo foi vinte vezes maior que a $1 \mathrm{~cm}$ da superfície do solo. Hargrove (1988) cita trabalho conduzido por Buresh et al.(1984) ${ }^{3}$, em casa de vegetação, no qual obtiveram perdas de 1 a $11 \%$ de $\mathrm{N}$ da uréia depositada a $6 \mathrm{~cm}$ de profundidade contra perdas de 16 a $28 \%$ de $\mathrm{N}$ quando a uréia foi depositada na superfície do solo. No nordeste do Brasil, Silva et al. (1995), comparando os métodos de aplicação de uréia nas doses de 0,60 , 120 e $180 \mathrm{~kg} \cdot \mathrm{ha}^{-1}$, depositado na superfície, na camada de $0-10 \mathrm{~cm}$ e a 10 cm da superfície, encontraram perdas por volatilização de $\mathrm{N}$ na faixa de $20-58 \%, 1,3-7,7 \%$ e $0,9-2,3 \%$, respectivamente. Rodrigues \& Kiehl (1986) aplicaram uréia incorporada a $0-2,0-5$ e $5 \mathrm{~cm}$ de profundidade, nas dosagens de 120, 180 e $240 \mathrm{~kg} \cdot \mathrm{ha}^{-1}$ de $\mathrm{N}$, sendo que mesma na incorporação realizada a $5 \mathrm{~cm}$ encontram perdas de $\mathrm{NH}_{3}$ variando de 35 a $62 \%$. Os mesmos autores observaram que, na maior profundidade, a perda foi menor e proporcional às dosagens aplicadas. Porém, Muzilli (1991), Christianson et al.(1995) afirmam que as perdas de nitrogênio associado à hidrólise da uréia aplicada à lanço pode atingir $50-70 \%$ do total do $\mathrm{N}$ aplicado.

Se as gramíneas de maior relação $\mathrm{C} / \mathrm{N}$ possuem a capacidade de melhorar a estrutura dos solos pela maior formação de ácidos húmicos devido à fração lignina (Primavesi, 1984), as leguminosas possuem a

\footnotetext{
${ }^{3}$ BURESH, R.J.; VLEK, P.L.G.; STUMPE, J.M. Labeled nitrogen fertilizer reseacher with urea in the semi-arid tropics. I. Greenhouse studies. Plant Soil. v. 80, p. 3-19, 1984.
} 
vantagem de propiciar a fixação simbiótica do nitrogênio atmosférico (Buckmam \& Brady, 1979). Assim, em trabalho conduzido por Derspch et al.(1991), o tremoço (Lupinus sp.) incorporou ao solo cerca de $90 \mathrm{~kg} . \mathrm{ha}^{-1}$ de $\mathrm{N}$, enquanto que aveia preta (Avena sp.) e nabo forrageiro (Raphanus sativus) acumularam cerca de 147 e $135 \mathrm{~kg}^{-h^{-1}}$ de $\mathrm{N}$, respectivamente. Entretanto, deve-se levar em conta que o $\mathrm{N}$ liberado pelo tremoço (Lupinus sp.) encontra-se mais prontamente disponível que o $\mathrm{N}$ acumulado no nabo forrageiro e, principalmente, na aveia preta. Ambrosano (1994), estudando a dinâmica do nitrogênio da mucuna-preta (Mucuna aterrima) e crotalária júncea (Crotalaria juncea), marcado com ${ }^{15} \mathrm{~N}$, em milho, encontrou maior disponibilidade de $\mathrm{N}$ proveniente da mucuna. Entretanto, as perdas de $\mathrm{N}$ no sistema solo-planta também foram maiores para essa leguminosa. $\mathrm{O}$ referido autor inferiu que a razão para esse fato, deveu-se mais à diferença na relação $\mathrm{C} / \mathrm{N}$ e na taxa de mineralização entre ambas.

\subsection{Crotalaria juncea Linn.}

A Crotalaria juncea L. pertence a família Leguminosae, sub-família Papilionoidae, tribo Genistae e ao gênero Crotalaria., sendo que esse abrange cerca de 500 espécies de plantas herbáceas, arbustivas anuais e perenes, apresentando distribruição pantropical e subtropical.

Conforme relatado por Medina (1959), a Crotalaria juncea L. é originária da Ásia meridional, provavelmente da Índia. Desde época remota, vem sendo cultivada nesse país como planta têxtil, forrageira e adubo verde. Segundo Bulisani \& Braga (1985) e Salgado et al.(1980), no Brasil, além de biofertilizante, essa espécie foi utilizada para produção de fibra, componente para papéis de qualidade, principalmente para cigarros, apresentando adequada combustão, deixando pouca presença de cinza e ausência de sabor ou cheiro.

Atualmente, a mencionada espécie deixou de ser cultivada no Brasil como fonte de matéria-prima para a fabricação de papel de cigarro. Isso, em razão de opções de importações de celulose por empresas 
coligadas às industrias fumageiras. Por outro lado, a importância da crotalária júncea cresceu como adubo verde.

A crotalária júncea sofre restrição a expansão de sua área como planta para adubação verde ou produtora de fibras por problema fitossanitário causado pelo fungo Ceratocistis fimbriata Ell \& Hals e, principalmente, pela sua dificuldade de produção de semente (Costa \& Amaral, 1976). Conforme descreve Allard (1960). É uma planta alógama e de polinização essencialmente entomófila, apresenta autoincompatibilidade para fecundação, além de evidências de protandria, que corresponde a maturação dos grãos de pólen antes da receptividade completa do estigma.

Trabalho de seleção a partir de uma planta de crotalária júncea com característica de autocompatibilidade foi realizado por Costa et al.(1973). Mais tarde, as linhagens provenientes dessa planta foram testadas na presença e ausência de insetos por Costa \& Amaral (1976). Os autores confirmaram autocompatibilidade dos materiais, sendo que a produção de sementes foi maior nas duas condições, comparado com a testemunha - composta por plantas conhecidamente autoincompatíveis.

A crotalária júncea possui flor cleistogâmica, com estigma protegido por quilha rígida, a qual necessita ser pressionada para permitir a exposição da massa de pólen para fora da quilha. Howard et al.(1919) ${ }^{4}$, citado por Free (1994), observaram que quando um inseto pesado, como a Megachile anthracine ou Xylocopa amethystina, pousa sobre a flor da crotalária júncea pressionando a quilha, o estigma e a massa de pólen é forçada contra o abdomen do inseto, promovendo sua aderência, o que possibilita a transferência para outras flores e plantas. Por essa razão, himenópteros de grande porte, como mamangavas, conseguem polinizar a crotalária júncea.

Em estudo observando a frequência de visitas e o comportamento das abelhas nativas em vários estágios de desenvolvimento da planta, por diversas vezes durante o dia, Nogueira et al. (1992)

\footnotetext{
${ }^{4}$ HOWARD, A.; HOWARD, G.L.; RAHMAN, K. A. Studies in the pollination of India crops. Mem. Dep. Agric. Indian Bot. Servic., v. 10, p. 195-220, 1919.
} 
observaram a presença de nove espécies desses insetos. As abelhas mamangavas Xylocopa frontalis, $X$. grisescens, Megachile orba e Megascirtetica mephistophelica apresentaram 49,7\%, 19,1\%, 17,6\% e $13,6 \%$, respectivamente, da freqüência às flores. Entretanto, a mais eficiente polinizadora foi a Xylocopa grisescens, que com o largo tamanho de seu corpo, permitiu maior pressão à quilha e maior contato dos grãos de pólen com seu abdomen. Entretanto, Amaral $(1955)^{5}$, citado por Costa \& Amaral (1976), pode comprovar que as abelhas irapuás (Trigona spinipes Fabr.) são realmente agentes de polinização da crotalária júncea.

Além do valor industrial, a crotalária júncea, também pode contribuir para a redução da população de nematóides. Trabalhos conduzidos por Santos \& Ruano (1987) e por Silva \& Carneiro (1992) dão conta que a crotalária júncea é má hospedeira de nematóide Meloidogyne javanica e Meloidogyne incognita, exceção feita às raças 2 e 4.

Vários são os resultados experimentais destacando o aumento de rendimentos de culturas que sucederam a crotalária júncea como adubo verde. Assim, Miyasaka et al.(1983) relataram que, no período de 1951/1956, foram conduzidos experimentos de algodão semeado após o enterrio de diversas leguminosas, das quais destacaram-se a Crotalaria paulinia L., Crotalaria juncea L. e Mucuna aterrima L. (mucuna-preta), com incremento médio de $25 \%$ na produção, comparados com as parcelas onde o algodão foi semeado continuamente. Cardoso (1956) e Wutke \& Alvarez (1968), em trabalhos de reformas de canaviais conduzidos no Estado de São Paulo, determinaram que a crotalária júncea propiciou aumento em torno de $20 \%$ no rendimento da cana-de-açúcar, colhida posteriormente. Também avaliando o efeito residual de leguminosas na reforma de canaviais, Mascarenhas et al. (1994) compararam soja, mucunapreta, crotalária júncea, a prática do alqueive e alqueive com a adição de $40 \mathrm{~kg} \cdot \mathrm{ha}^{-1}$ de N. Os resultados desse experimento mostraram que, na média de 3 anos, o acréscimo na produção de cana foi de $22 \%$ para crotalária, $20 \%$ para mucuna, $7 \%$ para alqueive $+\mathrm{N}$ e $4 \%$ para soja em relação ao

\footnotetext{
${ }^{5}$ Amaral, E. As abelhas irapuás e a polinização da Crotalaria juncea Linn. São Paulo: Suplemento Agrícola de O Estado de São Paulo, 1955, 36:14.
} 
alqueive. No entanto, a sucessão soja-cana auferiu maior lucro. Da mesma forma, Veiga et al.(1982) observaram resposta significativa da crotalária júncea no rendimento do feijoeiro e a possibilidade da dispensa da adubação nitrogenada de cobertura nessa cultura.

Ainda, a Crotalaria juncea L. apresenta potencial para promover melhoria do solo, redução da presença de plantas daninhas e aumento das produções das culturas que a sucedem. Essa espécie possui rápido processo de germinação, emergência, cobertura do solo e alta produção de biomassa, bem como acentuado potencial para a fixação de cerca de 150-165 kg.ha- ${ }^{-1}$ ano $^{-1}$ de N (Franco \& Souto, 1984 e Calegari, 1995). Outro trabalho conduzido por Veiga et al.(1982), no Estado de São Paulo, demonstrou que a parte aérea da crotalária júncea pode incorporar até $240 \mathrm{~kg} \cdot \mathrm{ha}^{-1}$ de $\mathrm{N}$ em um total de cerca de $12 \mathrm{t}^{\mathrm{ha}} \mathrm{h}^{-1}$ de matéria seca.

Além dos atributos como planta fornecedora de nitrogênio para o sistema, possui a característica desejada de um adubo verde para ser usado nas condições de plantio direto em regiões tropicais e sub-tropicais, que é a relação $\mathrm{C} / \mathrm{N}$ em torno de 25-35:1, dependendo de seu estádio fenológico. Essas características propiciam as vantagens de uma decomposição mais lenta de sua fitomassa, além de proteger o solo e atenuar a pressão dos rodados dos tratores, evitando a compactação pelo tráfego de máquinas, fato de ocorrência comum no sistema de plantio direto.

A crotalária júncea, é planta sensível ao fotoperíodo, apresentando menor porte e florescimento mais precoce quando sua fase vegetativa ocorre em fotoperíodo de dias curtos. Entretanto, pelo seu rápido crescimento e cobertura do solo, propicia algumas vantagens de interesse agronômico, objetivando a viabilização do sistema de plantio direto nas regiões acima do paralelo $24^{\circ}$, no Estado do Paraná. Dessa forma, é possível sua utilização para cobertura do solo, no período de outono, após colheita de milho ou soja, antecedendo a cultura do trigo. 


\section{MATERIAL E MÉTODOS}

\section{1. Área experimental}

O experimento foi instalado na Estação Experimental do IAPAR-Instituto Agronômico do Paraná, no município de Palotina, no extremo Oeste do Estado do Paraná, situado a $24^{\circ} 18^{\prime}$ de latitude sul e $53^{\circ} 55^{\prime}$ de longitude oeste, a $360 \mathrm{~m}$ de altitude, em solo classificado como Latossolo Roxo eutrófico, representativo da região.

Antes da implantação do experimento, a área foi cultivada com as seguintes culturas: soja no verão de 1989, triticale no inverno de 1990 e milho no verão desse mesmo ano, com o intuito de proceder a uniformização da gleba experimental.

\subsubsection{Amostragem do solo e análises}

Após o procedimento mencionado, foram retiradas amostras de solo para análise química nas profundidades de 0-10 e 10-20 cm. Inicialmente as amostras para caracterização da estabilidade dos agregados foram realizadas nas seguintes profundidades: 0-10, 10-20 e 20-30 cm.

No final do período experimental foram retiradas amostras de solo em cada parcela, sendo que para análise química as profundidades adotadas foram de 0-10 e 10-20 cm; para estabilidade dos agregados de 0$10 \mathrm{~cm}$ e para fracionamento da matéria orgânica de $0-3 \mathrm{~cm}$ de profundidade. 
As análises químicas do solo foram realizadas seguindo metodologias descritas por Pavan et. al.(1992), valendo-se do $\mathrm{CaCl}_{2}$ para a determinação do $\mathrm{pH}$ e do método Mehlich - 1, para a extração do fósforo e do potássio, cujos dados são apresentados na tabela 1 .

Para análise de estabilidade dos agregados foram coletadas amostras de solo, no estado de friabilidade, de 0-5 cm. No laboratório, a amostra foi submetida ao processo de tamisamento úmido em peneiras de $8,2,1,0.5,0.25 \mathrm{~mm}$ e menor que 0.25 . O material retido no tamis de 2 $\mathrm{mm}$ foi utilizado para determinação da estabilidade dos agregados, segundo método proposto por Yoder (1936).

Para a análise do fracionamento da matéria orgânica do solo foram retiradas amostras em cada parcela, na profundidade de 0-3 cm. Ressalta-se que os extratores utililizados foram o pirofosfato de sódio e o hidróxido de sódio, seguindo metodologia desenvolvida por Dabin (1976).

Tabela 1. Valores da análise química do solo em duas profundidades, amostrado no início do ano agrícola 91/92.

\begin{tabular}{|c|c|c|c|c|c|c|c|c|c|c|c|c|}
\hline Prof. & $\mathrm{pH}$ & $P$ & . & Al & $\mathrm{V}$ & \multicolumn{7}{|c|}{$\mathrm{meg} / 100 \mathrm{ml} \mathrm{de}$ solo } \\
\hline $\mathrm{cm}$ & $\mathrm{CaCl}_{2}$ & $\mu \mathrm{g} / \mathrm{cm}^{3}$ & & $\%$ & & $\mathrm{Al}$ & $\mathrm{H}+\mathrm{A}$ & $\mathrm{Ca}$ & $\mathrm{Mg}$ & $\mathrm{K}$ & $\mathrm{S}$ & $\mathrm{T}$ \\
\hline $0-10$ & 5.4 & 13.7 & 1.43 & 0.54 & 74 & 0.05 & 3.5 & 8.1 & 1.3 & 0.57 & 10.1 & 13.6 \\
\hline $0-20$ & 5.5 & 8.8 & 1.10 & 0.23 & 74 & 0.02 & 3.3 & 7.4 & 1.3 & 0.54 & 9.2 & 12.4 \\
\hline
\end{tabular}

Tabela 2. Valores percentuais de estabilidade dos agregados do solo dos tratamentos, na profundidade de $0-10 \mathrm{~cm}$, amostrado no início do ano 1991.

\begin{tabular}{c|cccccc} 
Trat. & $\mathrm{T}_{1}$ & $\mathrm{~T}_{2}$ & $\mathrm{~T}_{3}$ & $\mathrm{~T}_{4}$ & $\mathrm{~T}_{5}$ & $\mathrm{~T}_{6}$ \\
\hline$\%$ & 83,01 & 86,34 & 86,05 & 82,02 & 85,01 & 83,10
\end{tabular}




\subsubsection{Unidade experimental}

A unidade experimental foi composta por parcelas de $5 \mathrm{~m}$ de largura e $10 \mathrm{~m}$ de comprimento, sendo descontado como bordadura $1 \mathrm{~m}$ em todo o perímetro de cada parcela. A área total do experimento foi de 1.900 $\mathrm{m}^{2}$, abrangendo 6 tratamentos com quatro repetições cada.

O delineamento experimental adotado o foi de blocos casualizados apresentando quatro repetições.

\subsection{Clima}

As informações meteorológicas de precipitação pluvial, temperaturas (máximas e mínimas) e ocorrência de geadas foram registradas na Estação Agrometeorológica do IAPAR, localizada a $80 \mathrm{~m}$ da área experimental, cujos dados são apresentados nas figuras de 1 a 10.
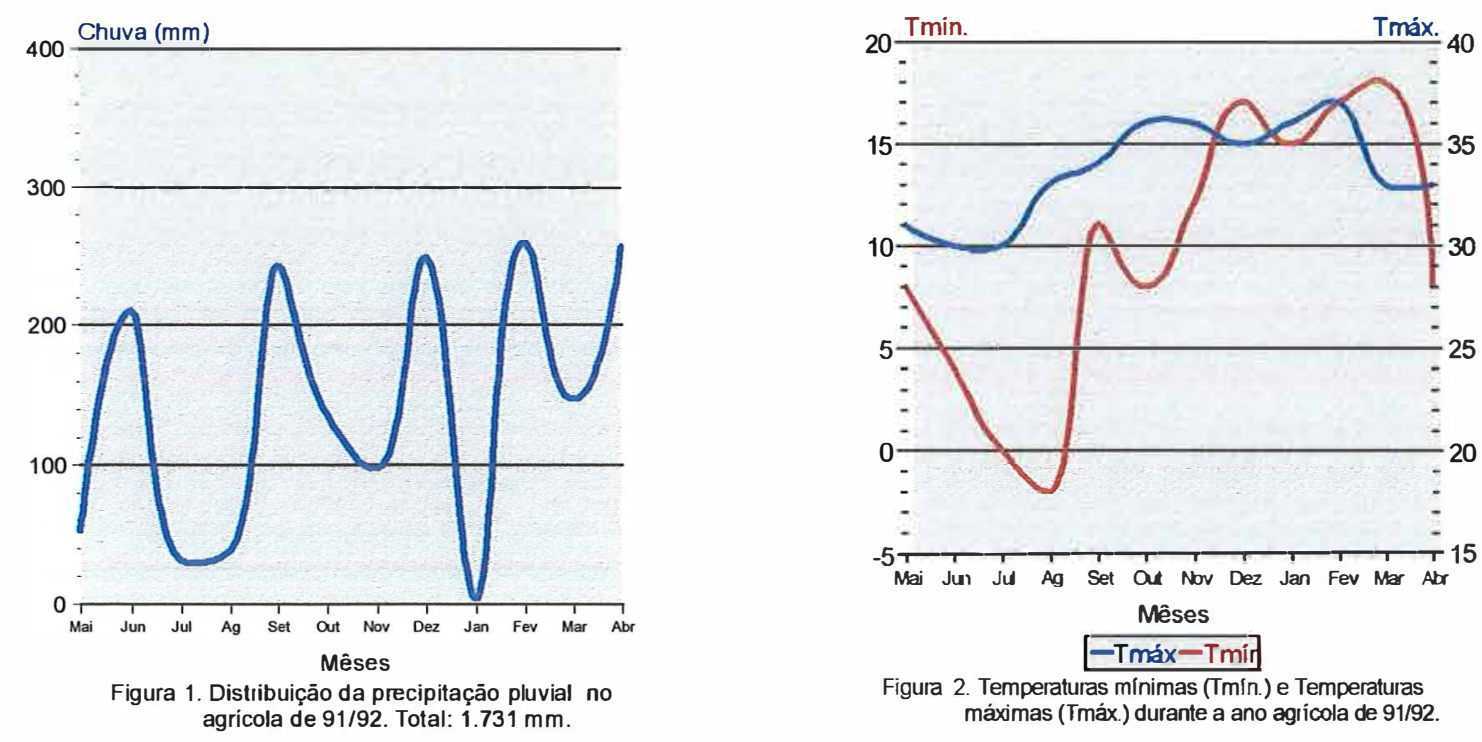


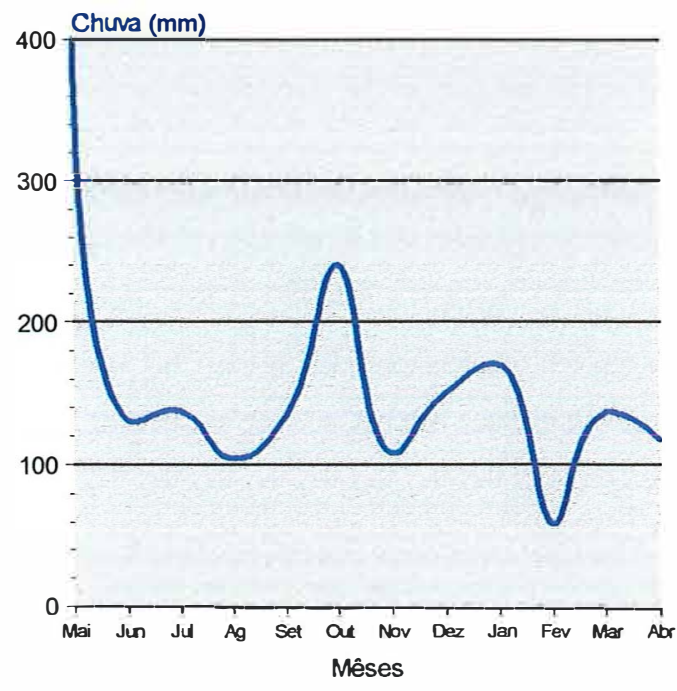

Figura 3. Distribuição da precipitação pluvial no ano agricola de $92 / 93$. Total: $1.919 \mathrm{~mm}$

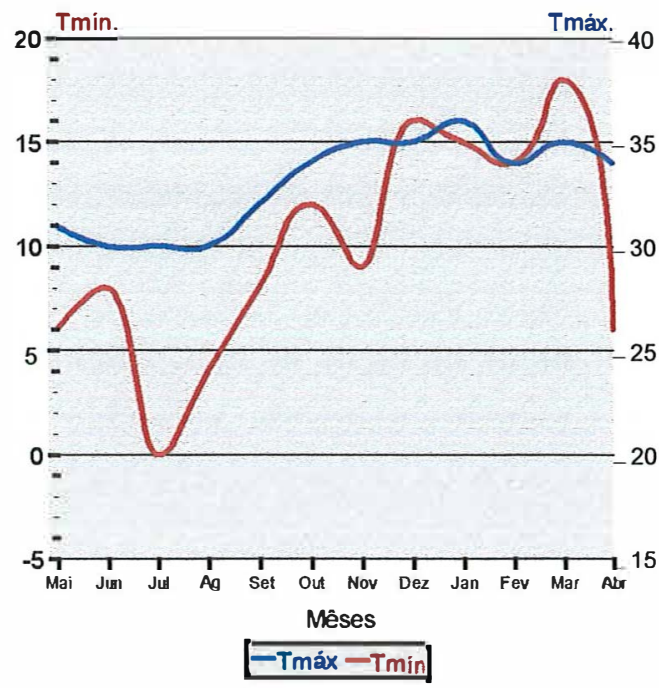

Figura 4. Temperaturas minimas (Tmin.) e temperaturas máximas (Tmáx.) durante a ano agricola de $92 / 93$.

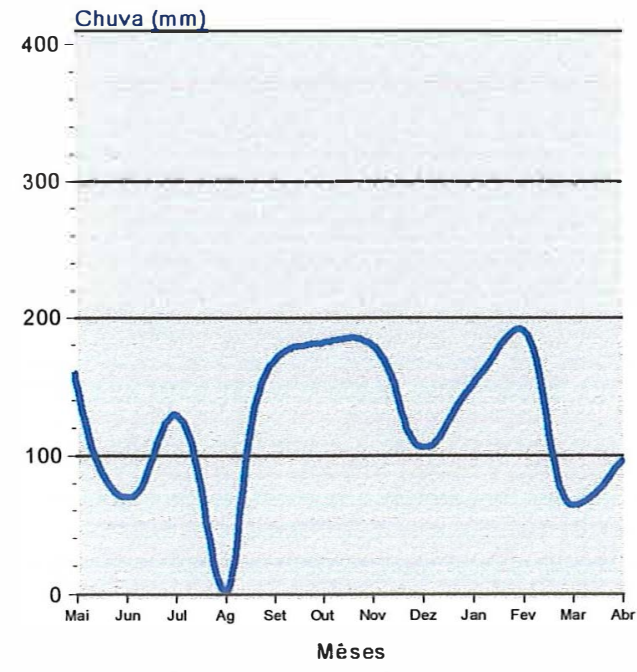

Figura 5. Distribuiçāo da precipitaçāo pluvial no ano agricola de $93 / 94$. Total: $1.494 \mathrm{~mm}$.

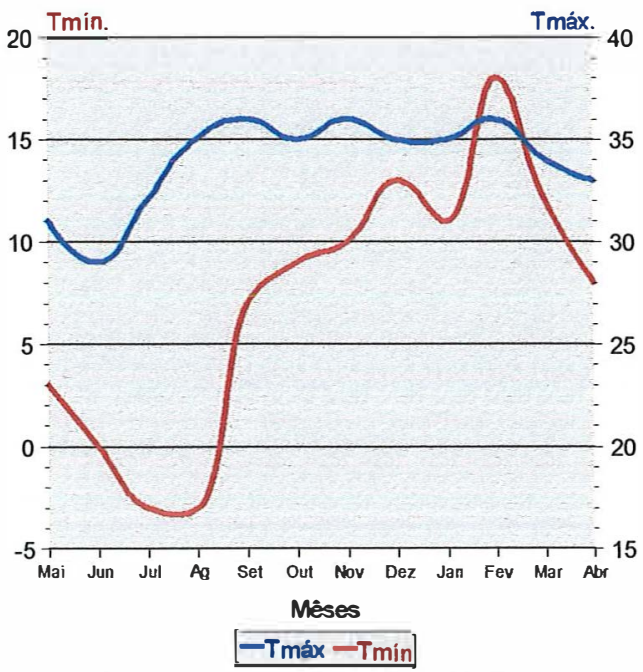

Figura 6. Temperaturas minimas (Tmin.) e temperaturas máximas (Tmáx.) durante a ano agricola de 93/94. 


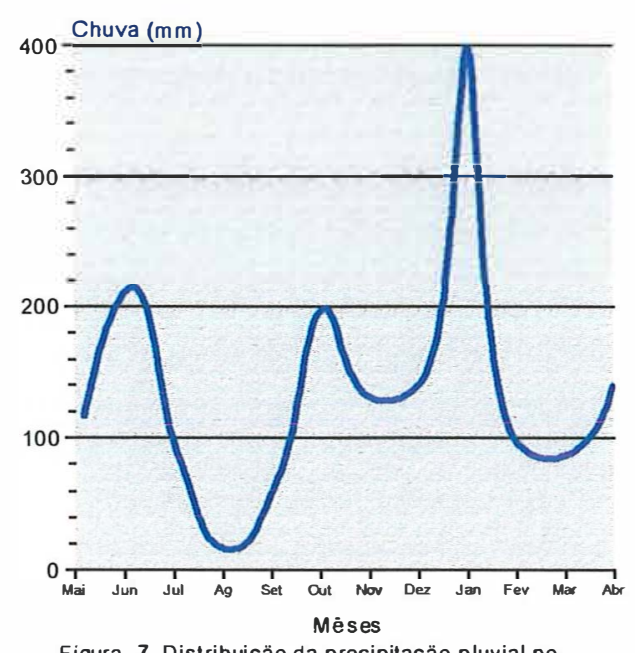

Figura 7. Distribuiçäo da precipitaçäo pluvial no agricola 94/95. Total: $1.836 \mathrm{~mm}$.

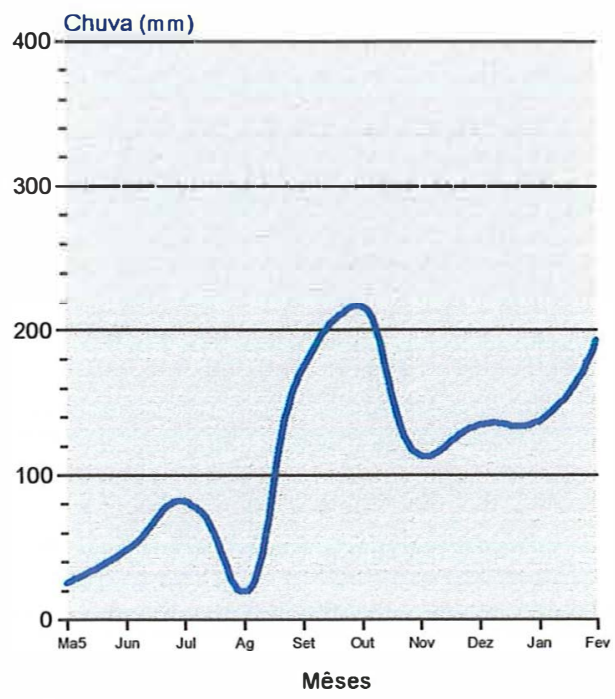

Figura 9. Distribuiçāo da precipitação pluvial no agricola de 95/96. Total: $1.139 \mathrm{~mm}$ (atè fev/96).

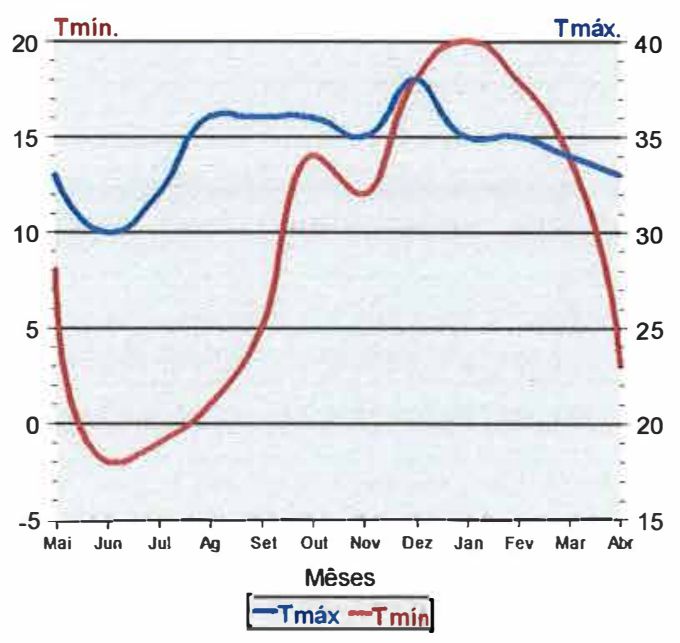

Figura 8. Temperaturas minimas (Tmin) e temperaturas máximas (Tmáx.) durante o ano agricola 94/95.

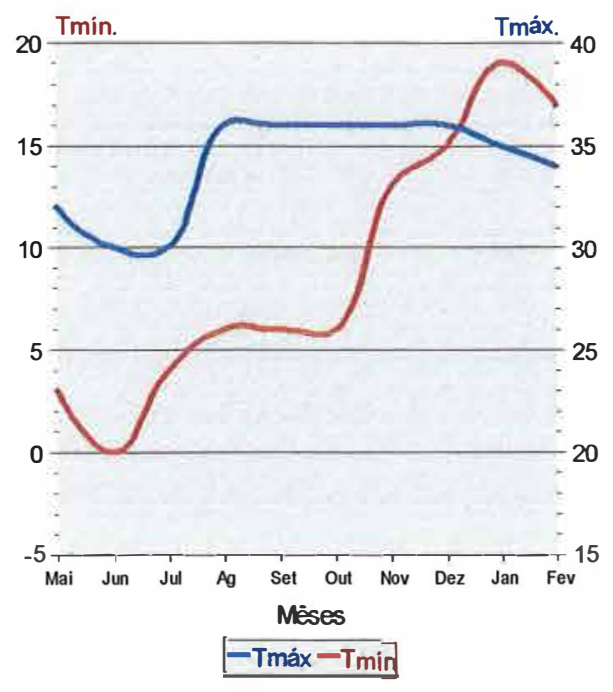

Figura 10. Temperaturas minimas (Tmin) e máximas (Tmáx) durante o ano agricola 95/96. (até fev/96). 


\subsection{Sistemas de sucessões de culturas e adubação mineral}

O período de execução do experimento abrangeu o inverno do ano de 1991 até o verão de 1996.

Os sistemas de sucessões adotados foram compostos com as culturas de milho, soja e trigo, exceto o tratamento $\mathrm{T}_{6}$, denominado de monocultura de soja-trigo, conforme discriminado na tabela abaixo.

Tabela 3. Calendário e disposição das sucessões de culturas dos tratamentos.

\begin{tabular}{|c|c|c|c|c|c|c|c|c|c|c|}
\hline & \multicolumn{2}{|c|}{$1991 / 92$} & \multicolumn{2}{|c|}{$1992 / 93$} & \multicolumn{2}{|c|}{$1993 / 94$} & \multicolumn{2}{|c|}{$1994 / 95$} & \multicolumn{2}{|c|}{$1995 / 96$} \\
\hline Trat & Inverno & Verão & Inverno & Verão & Inverno & Verão & Inverno & Verão & Inverno & Verão \\
\hline$T_{1}$ & $\begin{array}{c}\text { Crotal } \\
\text { Trigo } \\
30 \mathrm{~N}^{2}\end{array}$ & Soja & $\begin{array}{c}\text { Trigo } \\
30 \mathrm{~N}\end{array}$ & Milho & $\begin{array}{c}\text { Crotal } \\
\text { Trigo } \\
30 \mathrm{~N}\end{array}$ & Soja & $\begin{array}{c}\text { Trigo } \\
30 \mathrm{~N}\end{array}$ & Milho & $\begin{array}{c}\text { Crotal } \\
\text { Trigo } \\
30 \mathrm{~N}\end{array}$ & Soja \\
\hline $\mathrm{T}_{2}$ & $\begin{array}{l}\text { Crotal } \\
\text { Trigo } \\
60 \mathrm{~N}\end{array}$ & Soja & $\underset{60 \mathrm{~N}}{\text { Trigo }}$ & Milho & $\begin{array}{l}\text { Crotal } \\
\text { Trigo } \\
60 \mathrm{~N}\end{array}$ & Soja & $\underset{60 \mathrm{~N}}{\text { Trigo }}$ & Milho & $\begin{array}{l}\text { Crotal } \\
\text { Trigo } \\
60 \mathrm{~N}\end{array}$ & Soja \\
\hline $\mathrm{T}_{3}$ & Trigo & Soja & $\underset{30 \mathrm{~N}}{\text { Trigo }}$ & Milho & $\underset{30}{\text { Trigo }}$ & Soja & $\underset{30 \mathrm{~N}}{\text { Trigo }}$ & Milho & $\underset{30}{\text { Trigo }}$ & Soja \\
\hline $\mathrm{T}_{4}$ & $\begin{array}{c}\text { Crotal } \\
\text { Trigo } \\
0 \mathrm{~N}\end{array}$ & Soja & $\begin{array}{c}\text { Trigo } \\
0 \mathrm{~N}\end{array}$ & Milho & $\begin{array}{c}\text { Crotal } \\
\text { Trigo } \\
0 \mathrm{~N}\end{array}$ & Soja & $\begin{array}{c}\text { Trigo } \\
0 \mathrm{~N}\end{array}$ & Milho & $\begin{array}{c}\text { Crotal } \\
\text { Trigo } \\
0 \mathrm{~N}\end{array}$ & Soja \\
\hline $\mathrm{T}_{5}$ & $\begin{array}{l}\text { Trigo } \\
60 \mathrm{~N}\end{array}$ & Soja & $\begin{array}{c}\text { Trigo } \\
60 \mathrm{~N}\end{array}$ & Milho & $\begin{array}{c}\text { Trigo } \\
60 \mathrm{~N}\end{array}$ & Soja & $\begin{array}{c}\text { Trigo } \\
60 \mathrm{~N}\end{array}$ & Milho & $\begin{array}{c}\text { Trigo } \\
60 \mathrm{~N}\end{array}$ & Soja \\
\hline $\mathrm{T}_{6}$ & $\begin{array}{c}\text { Trigo } \\
30 \mathrm{~N}\end{array}$ & Soja & $\begin{array}{c}\text { Trigo } \\
30 \mathrm{~N}\end{array}$ & Soja & $\begin{array}{c}\text { Trigo } \\
30 \mathrm{~N}\end{array}$ & Soja & $\begin{array}{c}\text { Trigo } \\
30 \mathrm{~N}\end{array}$ & Soja & $\begin{array}{c}\text { Trigo } \\
30 \mathrm{~N}\end{array}$ & Soja \\
\hline
\end{tabular}

'Crotalária júncea.

${ }^{2}$ Nível de nitrogênio em cobertura, em kg.ha- ${ }^{-1}$.

Cumpre salientar que os tratamentos $T_{1}, T_{2}$ e $T_{4}$ possuem idênticos sistemas e ciclos rotacionais com milho/crotalária-trigo/soja, apenas diferindo entre si pelos níveis de 0,30 e $60 \mathrm{~kg} \cdot \mathrm{ha}^{-1}$ de $\mathrm{N}$ em cobertura para o trigo. Ainda, os tratamentos $T_{3}$ e $T_{5}$ envolveram a 
sucessão milho-trigo-soja, com 30 e $60 \mathrm{~kg} \cdot \mathrm{ha}^{-1}$ de $\mathrm{N}$ em cobertura para trigo, respectivamente; porém, com a ausência da crotalária júncea como adubação verde de entressafra após a colheita do milho.

As adubações foram consideradas tendo em vista a manutenção dos níveis de fertilidade constatado no resultado da análise do solo. Em todos os tratamentos e safras, o milho recebeu como adubação básica 8 kg.ha ${ }^{-1}$ de $\mathrm{N}, 26,2 \mathrm{~kg} \cdot \mathrm{ha}^{-1}$ de $\mathrm{P}$ e 16,7 kg.ha ${ }^{-1}$ de $\mathrm{K}$, sob a fórmula 4-30-10. A adubação nitrogenada de cobertura foi de $90 \mathrm{~kg}^{-\mathrm{ha}^{-1}} \mathrm{de} \mathrm{N}$, incorporado a $5 \mathrm{~cm}$ de profundidade no estádio de 6 a 8 folhas, sob a forma de sulfato de amônia.

O trigo, em todos tratamentos e safras, recebeu a mesma adubação básica do milho, variando apenas as adubações de cobertura, conforme já exposto.

A soja, em todos tratamentos e safras, recebeu $17,5 \mathrm{~kg} \cdot \mathrm{ha}^{-1}$ de $\mathrm{P}$ e $33,3 \mathrm{~kg} \cdot \mathrm{ha}^{-1}$ de $\mathrm{K}$, sob a fórmula 0-20-20, sendo que a inoculação das sementes de soja com Bradyrhizobium foi realizada apenas nas duas primeiras safras do período experimental.

\subsubsection{Cultivares utilizados}

As culturas foram conduzidas conforme tecnologia e recomendação da pesquisa, representado por tratos culturais comumente dispensados a lavouras comerciais.

O cultivar de milho utilizado foi o híbrido triplo Cargill 805, de porte médio, ciclo superprecoce, com florescimento aos 60 dias da emergência (condição local).

O cultivar de soja utilizada foi BR-16, de porte médio, ciclo semi-precoce e resistente ao canco da haste (Diaporthe phaseolorum f. sp. Meridionalis). 
Para trigo foi utilizado o cultivar IAPAR 29-Cacatu, nas três primeiras safras, substituído pela cultivar IAPAR 60 nas duas últimas safras, sendo o primeiro de ciclo intermediário e porte médio; o segundo de ciclo precoce e porte médio.

\subsection{Manejo da adubação verde}

Nos tratamentos afins, imediatamente após a colheita do milho, a crotalária júncea foi semeada em sistema direto, onde permaneceu vegetando por 70 dias. Ao término desse período, com o solo seco, foi empregado o rolo-faca, quando as plantas apresentaram em média 1,60 $1,80 \mathrm{~cm}$ de altura, objetivando o manejo da fitomassa produzida. Simultaneamente ao corte da crotalária, o trigo foi semeado sobre a fitomassa fresca da leguminosa. A semeadora de trigo foi tracionada no sentido longitudinal dos colmos da crotalária, já prostrados no solo, ou seja, no mesmo sentido de operação do rolo-faca.

Para a semeadura do adubo verde foi utilizado semeadora de plantio direto de soja/trigo, com disco de corte desencontrado, distribuindo 15-20 sementes por metro linear, no espaçamento de $40 \mathrm{~cm}$ entrelinhas, perfazendo um total de $25 \mathrm{~kg}$. ha ${ }^{-1}$ de sementes.

Momento antes do manejo do adubo verde, amostras de fitomassa foram coletas em $1 \mathrm{~m}^{2}$, em cada parcela, que posteriormente foram colocadas em estufa a $65^{\circ} \mathrm{C}$ por 72 horas para a determinação da produção de matéria seca da área.

\subsection{Manejo do solo e das culturas}

Nos anos de 1992 e 1993, as culturas de verão foram semeadas utilizando como preparo do solo a prática da escarificação, acompanhada de uma gradeação. No mesmo período, as safras de inverno foram 
implantadas por semeadura direta. A partir de 1994, adotou-se o sistema de plantio direto para todas as culturas.

Com relação às culturas da soja e trigo, todas as operações de semeadura e aplicações de insumos foram mecanizadas, simulando condições de lavouras comerciais, sendo a colheita realizada por colhedora de parcelas experimentais de marca Nursery-Master.

Para milho, foram efetuadas semeaduras e colheitas manuais, sendo que após as colheitas, os restos culturais do milho foram manejados com rolo-faca, objetivando a adequação da área para as culturais posteriores.

\subsection{Desempenho econômico dos sistemas}

As análises econômicas foram adaptadas de metodologias apresentadas por Neves \& Shirota (1986), baseadas em fluxo de caixa, custos operacionais de situação ex-post, concluindo com a demonstração da relação benefício/custo financeiro dos sistemas

Os valores monetários dos insumos, das operações mecanizadas e da mão-de-obra foram transformados em valores relativos a cotação da moeda norte-americana, ou seja, o dólar (US\$) da época da realização. No final do ciclo experimental tais valores foram transformados em valor monetário vigente no país (Real $=\mathrm{R} \$$ ).

Os valores de comercialização de trigo, soja e milho foram baseados nos preços médios praticados no mercado internacional. Assim, para o saco de $60 \mathrm{~kg}$ de trigo, soja e milho, considerou-se os preços de $\mathrm{R} \$$ $7,74, \mathrm{R} \$ 11,50$ e $\mathrm{R} \$ 7,00$, respectivamente. 


\subsection{Análise do balanço energético}

Para avaliação dos balanços energético dos sistemas de sucessões de culturas foram considerados todas as operações mecanizadas e manuais, bem como o emprego de insumos a cada safra durante o quinquênio experimental. Os coeficientes energéticos, expressos em calorias, foram baseados em metodologias propostas por Heichel (1980), Pimentel (1980) e Mello (1986). Especificamente para o N-sulfato de amônio, foi utilizado o coeficiente energético obtido por Felippe Júnior (1984).

Com o objetivo de estabelecer a comparação entre os tratamentos a cada safra, foram adotados os índices de Eficiência Energética - EE e de Eficiência Cultural - EC. O primeiro é baseado no fluxo de entrada e saída de energia do sistema, sendo a razão entre os fluxos. O segundo índice - EC - é o resultado da divisão do rendimento de grãos $\left(\mathrm{kg} \cdot \mathrm{ha}^{-1}\right)$ pelo total de calorias envolvidas no processo produtivo.

1) $\mathbf{E E}=$ entrada de energia $\left(\right.$ mcal.ha $\left.^{-1}\right)$. saída de energia $\left(\text { mcal.ha }^{-1}\right)^{-1}$

2) $\mathbf{E C}=$ Rendimento de grãos $\left(\mathrm{kg} \mathrm{ha}^{-1}\right)$. Energia cultural (caloria) ${ }^{-1}$

Ainda, os valores de saída de energia foram baseados na quantidade de energia metabolizada ou valor calorimétrico dos grãos nos níveis de $3.483 \mathrm{kcal}, 3.285 \mathrm{kcal}$ e $4.022 \mathrm{kcal}$ para cada quilograma de grãos de milho, trigo e soja, respectivamente, conforme atribuído por Pimentel \& Burgess (1980), Briggle (1980) e Scott \& Krummem (1980).

\subsection{Parâmetros avaliados e análises estatísticas}




\subsubsection{Rendimento de grãos}

O principal componente de produção avaliado foi o rendimento de grãos de soja, milho e trigo, os quais foram corrigidos a $13,5 \%$ de umidade. As análises estatísticas para esse componente foram realizadas empregando o Teste de Duncan a $5 \%$ de probabilidade.

\subsubsection{Composição química do solo}

No final do período experimental foram avaliados os teores de $\mathrm{P}, \mathrm{K}, \mathrm{Ca}+\mathrm{Mg}, \mathrm{pH}, \mathrm{H}+\mathrm{Al}$ e M.0. e submetido ao Teste $\mathrm{F}$ a $5 \%$ de probabilidade. Para as variáveis que apresentaram diferença estatística, foi realizado o Teste de Duncan a 5\% de probabilidade.

\subsubsection{Análise da estabilidade dos agregados}

Encerrado o período experimental, foram retiradas amostras de solo, para análise de estabilidade dos agregados, cujos resultados foram submetidos a análise estatística pelo Teste de Duncan a 5\% de probabilidade.

\subsubsection{População de plantas daninhas.}

Foram realizadas duas avaliações da população de plantas daninhas. A primeira foi realizada no momento do manejo da crotalária e semeadura do trigo; a segunda, no ano seguinte, imediatamento antes da semeadura do trigo. Os dados foram submetidos a análise estatística pelo Teste de Duncan a $5 \%$ e $1 \%$ de probabilidade. 


\subsubsection{Avaliação dos resultados econômicos dos sistemas}

Para a análise estatística dos resultados econômicos das sucessões de culturas, a receita líquida de cada safra foi considerada como sendo uma repetição, perfazendo um total de dez repetições. Devido às perdas totais por geadas em trigo nos anos de 1991 e 1994, ocorreu alto grau de variância entre os valores. Com o objetivo de facilitar a análise e interpretação dos resultados, foi considerado o valor negativo encontrado no tratamento $\mathrm{T}_{6}$, nas safras inverno de 1991 e 1994, como crédito a todos tratamentos, a título de seguro agrícola. Da mesma forma, a análise estatística foi realizada pelo Teste de Duncan a $5 \%$ de probabilidade.

\subsubsection{Balanço energético}

Para análise de balanço energético, foi considerado cada safra como sendo uma repetição, perfazendo um um total de oito safras. As safras de trigo, que apresentaram perdas totais por geadas, não foram consideradas para efeito dos cálculos estatísticos. As análises estatísticas foram realizadas para Eficiência Energética (EE) e Eficiência Cultural (EC), empregando o Teste de Duncan a $5 \%$ e $1 \%$ de probabilidade. 


\section{RESULTADOS E DISCUSSÃO}

\subsection{Rendimentos de grãos de trigo, soja e milho}

Com o objetivo de uniformização da área, antecedendo a implantação do experimento, foram implantadas as culturas de soja, triticale e milho, no verão de 1989 e no ano de 1990. Conforme se observa nas figuras de 1 a 10 , durante o quinquênio experimental, as condições climáticas foram marcadas por adversidades extremas. A tabela 4 mostra os rendimentos obtidos para cada tratamento e para cada safra avaliada.

Tabela 4.Rendimentos de grãos $\left(\mathrm{kg} \cdot \mathrm{ha}^{-1}\right)$ das culturas no período - 8 safras.

\begin{tabular}{|c|c|c|c|c|c|c|c|c|c|c|}
\hline \multirow[b]{2}{*}{ Trat } & \multicolumn{2}{|c|}{$1991 / 92$} & \multicolumn{2}{|c|}{$1992 / 93$} & \multicolumn{2}{|c|}{$1993 / 94$} & \multicolumn{2}{|c|}{$1994 / 95$} & \multicolumn{2}{|c|}{$1995 / 96$} \\
\hline & Inverno & Verão & Inverno & Verão & Inverno & Verão & Inverno & Verão & Inverno & Verão \\
\hline $\mathrm{T}_{1}$ & $\begin{array}{c}\text { Crotal }^{1} \\
\text { Trigo }_{30}\end{array}$ & $\begin{array}{c}\text { Soja } \\
2.575\end{array}$ & $\begin{array}{c}\operatorname{Trigo}_{30}{ }^{2} \\
3.250\end{array}$ & $\begin{array}{l}\text { Milho } \\
8.014\end{array}$ & $\begin{array}{c}\text { Crotal } \\
\text { Trigo }_{30} \\
2.609\end{array}$ & $\begin{array}{c}\text { Soja } \\
3.286\end{array}$ & Trigo $_{30}$ & $\begin{array}{l}\text { Milho } \\
5.428\end{array}$ & $\begin{array}{c}\text { Crotal } \\
\text { Trigo }_{30} \\
1387\end{array}$ & $\begin{array}{l}\text { Soja } \\
3581\end{array}$ \\
\hline $\mathrm{T}_{2}$ & $\begin{array}{c}\text { Crotal } \\
\text { Trigo }_{60}\end{array}$ & $\begin{array}{c}\text { Soja } \\
2.593\end{array}$ & $\begin{array}{c}\text { Trigo }_{60} \\
3.466\end{array}$ & $\begin{array}{l}\text { Milho } \\
8.388\end{array}$ & $\begin{array}{c}\text { Crotal } \\
\text { Trigo }_{60} \\
2.694\end{array}$ & $\begin{array}{c}\text { Soja } \\
3.602\end{array}$ & Trigo $_{60}$ & $\begin{array}{l}\text { Milho } \\
5.296\end{array}$ & $\begin{array}{c}\text { Crotal } \\
\text { Trigo }_{60} \\
1326\end{array}$ & $\begin{array}{l}\text { Soja } \\
3607\end{array}$ \\
\hline $\mathrm{T}_{3}$ & Trigo $_{30}$ & $\begin{array}{c}\text { Soja } \\
2.427\end{array}$ & $\begin{array}{c}\text { Trigo }_{30} \\
3.132\end{array}$ & $\begin{array}{l}\text { Milho } \\
8.058\end{array}$ & $\begin{array}{c}\text { Trigo }_{30} \\
2.232\end{array}$ & $\begin{array}{l}\text { Soja } \\
3.133\end{array}$ & Trigo $_{30}$ & $\begin{array}{l}\text { Milho } \\
4.213\end{array}$ & $\begin{array}{c}\text { Trigo }_{30} \\
1194\end{array}$ & $\begin{array}{l}\text { Soja } \\
3201\end{array}$ \\
\hline $\mathrm{T}_{4}$ & $\begin{array}{l}\text { Crotal } \\
\text { Trigo }\end{array}$ & $\begin{array}{c}\text { Soja } \\
2.555\end{array}$ & $\begin{array}{l}\text { Trigo }_{0} \\
3.000\end{array}$ & $\begin{array}{l}\text { Milho } \\
8.001\end{array}$ & $\begin{array}{l}\text { Crotal } \\
\text { Trigo }_{0} \\
1.888\end{array}$ & $\begin{array}{c}\text { Soja } \\
3.301\end{array}$ & Trigo $_{0}$ & $\begin{array}{l}\text { Milho } \\
4861\end{array}$ & $\begin{array}{c}\text { Crotal } \\
\text { Trigo }_{0} \\
1430\end{array}$ & $\begin{array}{r}\text { Soja } \\
3609\end{array}$ \\
\hline $\mathrm{T}_{5}$ & $\operatorname{Trigo}_{60}$ & $\begin{array}{c}\text { Soja } \\
2.233\end{array}$ & $\begin{array}{c}\text { Trigo }_{60} \\
3.285\end{array}$ & $\begin{array}{l}\text { Milho } \\
8.180\end{array}$ & $\begin{array}{c}\text { Trigo }_{60} \\
2.520\end{array}$ & $\begin{array}{c}\text { Soja } \\
3.248\end{array}$ & Trigo $_{60}$ & $\begin{array}{l}\text { milho } \\
4.432\end{array}$ & $\begin{array}{c}\text { Trigo }_{60} \\
1190\end{array}$ & $\begin{array}{l}\text { Soja } \\
3140\end{array}$ \\
\hline $\mathrm{T}_{6}$ & Trigo $_{30}$ & $\begin{array}{c}\text { Soja } \\
2.303\end{array}$ & $\begin{array}{c}\text { Trigo }_{30} \\
3.167 \\
\end{array}$ & $\begin{array}{c}\text { Soja } \\
2.655\end{array}$ & $\begin{array}{c}\text { Trigo }_{30} \\
2.595 \\
\end{array}$ & $\begin{array}{c}\text { Soja } \\
3.092\end{array}$ & Trigo $_{30}$ & $\begin{array}{r}\text { Soja } \\
2880 \\
\end{array}$ & $\begin{array}{c}\text { Trigo }_{30} \\
1073 \\
\end{array}$ & $\begin{array}{r}\text { Soja } \\
3288 \\
\end{array}$ \\
\hline
\end{tabular}




\subsubsection{Comportamento do trigo}

O trigo apresentou maior instabilidade de produção devido às adversidades climáticas, mencionadas anteriormente. Na safra 1991 houve perda total nos rendimentos de grãos em consequência de forte geada, ocorrida no dia $02 / 08 / 91$, atingindo a temperatura de $-2,2^{\circ} \mathrm{C}$ em condições de abrigo. No ano de 1994, também houve perda total provocada por geada de $-1,4^{\circ} \mathrm{C}$, no abrigo, ocorrida no dia 09/07/94. Nos anos de 1992 e 1993 também ocorreu o mesmo fenômeno; entretanto, o mesmo não causou danos pelo fato da cultura do trigo não se encontrar estádio fenológico crítico, ou seja, fase de espigamento, florescimento ou enchimento dos grãos.

Tendo em vista a maior probabilidade de ocorrência de geadas até no mês de julho, o que poderia acarretar significativo prejuízo à agricultura do Paraná, houve mudança na época de recomendação oficial de semeadura de trigo. Assim, para a região Oeste do Paraná (Região B e C), a época preferencial foi deslocada do período de abril/maio (IAPAR, 1986) para o mês de maio (IAPAR,1996). Em consonância com essas mudanças, dados apresentados na tabela 25 (Apêndice I) e registrados na Estação Agrometeorológica do IAPAR, no município de Palotina, dão conta que, nos últimos 21 anos, os trigos semeados nos meses de abril teriam sido afetados por geadas, por apresentarem-se na fase crítica para o fenômeno. Por outro lado, nesse mesmo período, os trigos semeados em meados do mês de maio, teriam sofrido apenas quatro anos de frustrações de safras devido à geadas ocorridas antes do mês de julho ou apenas no mês de agosto, não coincidindo, dessa forma, com o período crítico para essa lavoura.

Em todos os anos foram constatadas diferenças estatísticas entre tratamentos para trigo. Na safra 1995, com severo o déficit hídrico e altas temperaturas afetando os rendimentos de grãos, o tratamento $\mathrm{T}_{4}$ (trigo sem nitrogênio em cobertura) foi estatisticamente superior aos demais tratamentos (sem crotalária). 
Pelos resultados obtidos com trigo, evidencia-se que, para maiores rendimentos, a introdução da crotalária não foi suficiente para satisfazer as necessidades de nitrogênio para essa cultura. Possivelmente, mesmo sendo uma leguminosa com capacidade para fixar $154 \mathrm{~kg} \cdot \mathrm{ha}^{-1} \cdot \mathrm{ano}^{-1}$ de nitrogênio (FRANCO \& SOUTO, 1984), devido à sua alta relação $\mathrm{C} / \mathrm{N}$, pode ainda ocorrer a imobilização de $\mathrm{N}$, no mesmo período em que a necessidade do trigo é ascendente.

A mudança na época preferencial de semeadura do trigo, permite maior adoção do "sistema crotalária", por ampliar o período entre a colheita do milho e a semeadura do trigo de, aproximadamente, 80 para 100 dias. Todavia, período tão longo em pousio, principalmente em áreas de plantio direto, poderá inviabilizar o sistema, pelos fatores já expostos.

\subsubsection{Comportamento do milho}

As sucessões de culturas pré-estabelecidas no presente trabalho contemplam apenas duas safras de milho. Na safra do ano agrícola 92/93, as condições climáticas apresentaram-se normais, com boa distribuição de chuvas, garantindo excelente produção de milho; sendo que os tratamentos não apresentaram diferenças estätísticas. Entretanto, na safra de 94/95, ano com severo déficit hídrico e, principalmente, má distribuição pluvial, houve diferenças significativas entre os tratamentos. $O$ tratamento $T_{1}$, com crotalária, foi superior aos demais tratamentos $\left(T_{3}\right.$ e $\mathrm{T}_{5}$ ) sem crotalária. Os tratamentos com crotalária apresentaram maiores rendimentos de milho, possivelmente, por atenuar o efeito prejudicial do défice hídrico mencionado (tabela 5).

Nos tratamentos onde milho sucedeu trigo e foi utilizado $\mathrm{N}$ em cobertura, foram registrados os maiores rendimentos de grãos (tabela 5). Provavelmente, o milho se beneficiou do $\mathrm{N}$ residual, aplicado no trigo. Resultados semelhantes obtiveram Bujan et al.(1982), semeando soja inoculada, sorgo e soja adubados com sulfato de amônio contendo átomos de ${ }^{15} \mathrm{~N}$, na dosagem de 20 e $100 \mathrm{~kg} \cdot \mathrm{ha}^{-1}$ de $\mathrm{N}$. Os mesmos autores 
confirmaram a residualidade da adubação nitrogenada, após um ano, obtiveram resultados significativos pela análise foliar de $\mathrm{N}_{2}$ e pelo rendimento de grãos de trigo para os tratamentos em que foi empregado $100 \mathrm{~kg} \cdot \mathrm{ha}^{-1}$ de N.

Tabela 5. Rendimentos médios $\left(\mathrm{kg} \cdot \mathrm{ha}^{-1}\right)$ das culturas e resultados das análises estatísticas do quinquênio 1991/95.

\begin{tabular}{|c|c|c|c|c|c|c|c|c|}
\hline \multirow[b]{2}{*}{ Trat } & \multirow{2}{*}{$\frac{1921 / 22}{\text { Soja }}$} & \multicolumn{2}{|c|}{$-1222 / 23$} & \multicolumn{2}{|c|}{-1293124} & \multirow{2}{*}{$\frac{-1924 / 95}{\text { Milho }}$} & \multicolumn{2}{|c|}{$1995 / 96$} \\
\hline & & Trigo & Milho & Trigo & Soja & & Trigo & Soja \\
\hline $\mathrm{T}_{1}$ & $\begin{array}{l}2575 \text { a } \\
106^{1}\end{array}$ & $\begin{array}{l}3250 \text { a } \\
104\end{array}$ & $\begin{array}{l}8014 \text { a } \\
100\end{array}$ & $\begin{array}{l}2609 \text { a } \\
117\end{array}$ & $\begin{array}{l}\mathbf{3 2 8 6} \mathbf{a b} \\
109\end{array}$ & $\begin{array}{l}\mathbf{5 4 2 8} \text { a } \\
129\end{array}$ & $\begin{array}{l}1387 \mathbf{a b} \\
116\end{array}$ & $\begin{array}{l}3581 \text { a } \\
105\end{array}$ \\
\hline$T_{2}$ & $\begin{array}{l}2593 \text { a } \\
107\end{array}$ & $\begin{array}{l}3466 \text { a } \\
111\end{array}$ & $\begin{array}{l}8388 \text { a } \\
104\end{array}$ & $\begin{array}{l}2694 \text { a } \\
121\end{array}$ & $\begin{array}{l}3602 \text { a } \\
115\end{array}$ & $\begin{array}{l}\mathbf{5 2 9 6} \mathbf{a b} \\
126\end{array}$ & $\begin{array}{l}1326 \mathbf{a b} \\
111\end{array}$ & $\begin{array}{l}3607 \mathbf{a} \\
113\end{array}$ \\
\hline $\mathrm{T}_{3}$ & $\begin{array}{l}2427 \text { ab } \\
100\end{array}$ & $\begin{array}{l}3132 \text { b } \\
100\end{array}$ & $\begin{array}{l}8058 \mathbf{a} \\
100\end{array}$ & $\begin{array}{l}\mathbf{2 2 3 2} \text { b } \\
100\end{array}$ & $\begin{array}{l}\mathbf{3 1 3 3} \mathbf{b} \\
100\end{array}$ & $\begin{array}{l}\mathbf{4 2 1 3} \text { c } \\
100\end{array}$ & $\begin{array}{l}1194 \text { bc } \\
100\end{array}$ & $\begin{array}{l}3201 \text { a } \\
100\end{array}$ \\
\hline $\mathrm{T}_{4}$ & $\begin{array}{l}2555 \text { a } \\
105\end{array}$ & $\begin{array}{l}3000 \quad c \\
96\end{array}$ & $\begin{array}{l}8001 \text { a } \\
99\end{array}$ & $\begin{array}{l}1888 \\
85\end{array}$ & $\begin{array}{l}\mathbf{3 3 0 1} \mathbf{a b} \\
105\end{array}$ & $\begin{array}{l}\mathbf{4 8 6 1} \mathbf{a b} \\
115\end{array}$ & $\begin{array}{l}1430 \text { a } \\
120\end{array}$ & $\begin{array}{l}3609 \text { a } \\
113\end{array}$ \\
\hline $\mathrm{T}_{5}$ & $\begin{array}{l}2233 \text { b } \\
92\end{array}$ & $\begin{array}{l}\mathbf{3 2 8 5} \mathbf{a b} \\
105\end{array}$ & $\begin{array}{l}8180 \text { a } \\
102\end{array}$ & $\begin{array}{l}2520 \text { ab } \\
113\end{array}$ & $\begin{array}{l}3248 \text { ab } \\
104\end{array}$ & $\begin{array}{l}4432 \text { bc } \\
105\end{array}$ & $\begin{array}{l}1190 \text { bc } \\
100\end{array}$ & $\begin{array}{l}3140 \text { a } \\
97\end{array}$ \\
\hline $\mathrm{T}_{6}$ & $\begin{array}{l}\mathbf{2 3 0 3} \mathbf{a b} \\
95\end{array}$ & $\begin{array}{l}3167 \text { a } \\
101\end{array}$ & & $\begin{array}{l}2595 \text { a } \\
116 \\
\end{array}$ & $\begin{array}{l}\text { 3092 b } \\
99\end{array}$ & & $\begin{array}{l}1073 \\
90 \\
\end{array}$ & $\begin{array}{l}3288 \text { a } \\
101\end{array}$ \\
\hline $\mathrm{CV}^{2}$ & 7,74 & 8,56 & 6,21 & 8,56 & 7,83 & 14 & 11 & 10 \\
\hline $\mathrm{F}^{3}$ & $\mathrm{~S}^{*}$ & $\mathrm{~S}^{* *}$ & NS & $\mathrm{S}^{* *}$ & $\mathrm{~S}^{*}$ & $\mathrm{~S}^{*}$ & $\mathrm{~S}^{*}$ & NS \\
\hline
\end{tabular}

* Médias seguidas por letras iguais, em coluna, não diferem entre si pelo Teste de Duncan a $5 \%$ e 1\% de probabilidade.

${ }^{1}$ Em coluna, valores médios relativos ao $\mathrm{T}_{3}$-referência, em \%

${ }^{2}$ Coeficiente de variação, em \%.

${ }^{3}$ Teste de F para tratamentos.

\subsubsection{Comportamento da soja}

Em todas as safras de soja, os tratamentos $T_{1}, T_{2}$ e $T_{4}$, com crotalária, apresentaram superioridade nos rendimentos de grãos. Entretanto, essas superioridades não foram suficientes para garantir-lhes, igualmente, as diferenças estatísticas (tabela 5). A soja, sendo uma 
leguminosa que independe de adubação com $\mathrm{N}$-mineral, associada a performance genética do cultivar utilizado e às satisfatórias condições edafoclimáticas encontradas, apresentou-se menos responsiva à adubação verde com crotalária júncea. Desse fato, pode-se inferir que, em ensaios com adubação verde, conduzidos em solos argilosos de alta fertilidade, com características eutróficas e teores de matéria orgânica em torno de $3 \%$, a probabilidade de obtenção de diferenças significativas entre os tratamentos é baixa, comparado com solos de características agronômicas inferiores.

As figuras 11 a 21, apresentam os rendimentos acumulados e rendimentos relativos das culturas de trigo, soja e milho, nas safras agrícolas avaliadas.

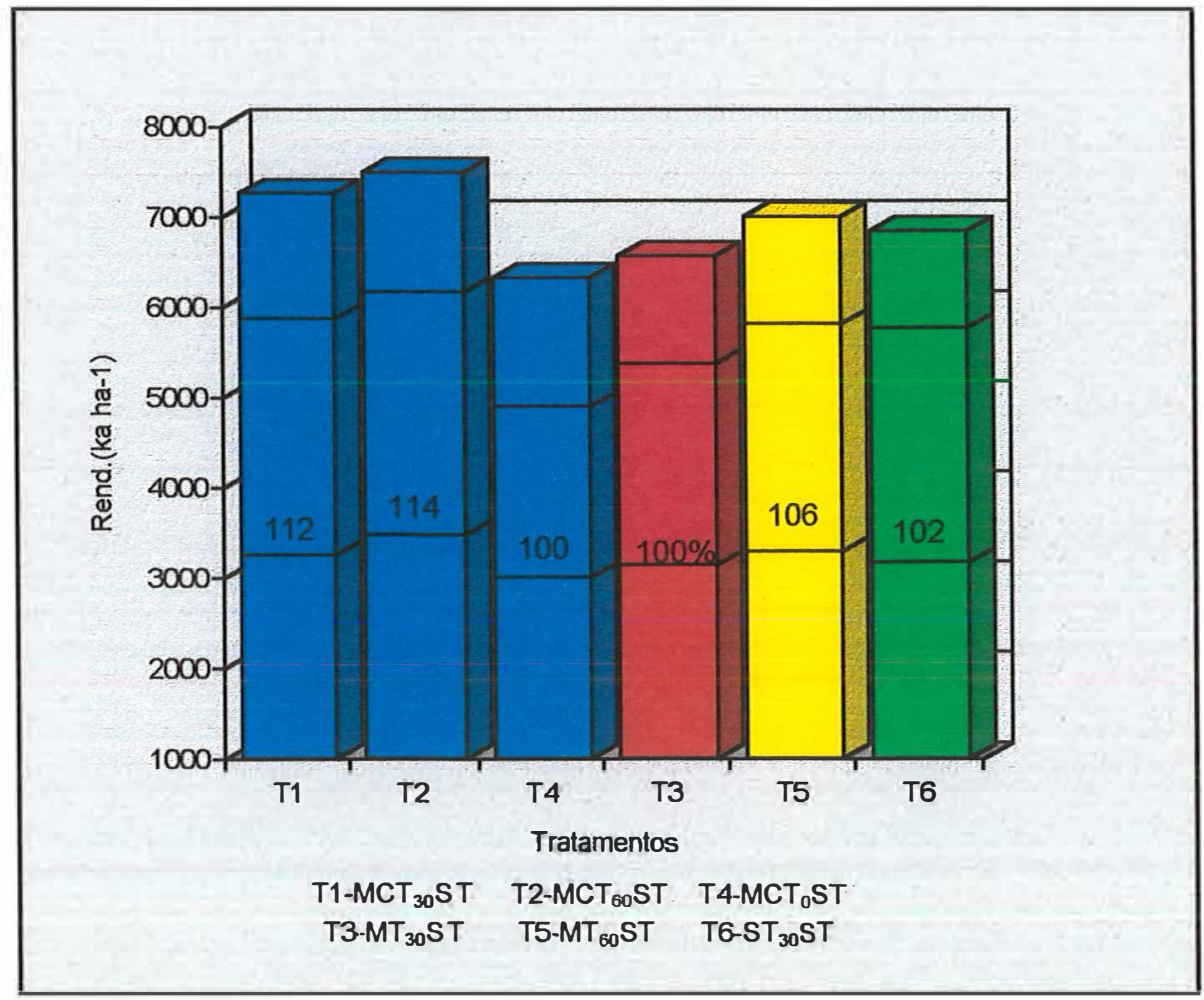

Figura 11. Rendimentos acumulados relativos (\%) de trigo safras 1992, 1993 e 1995. 


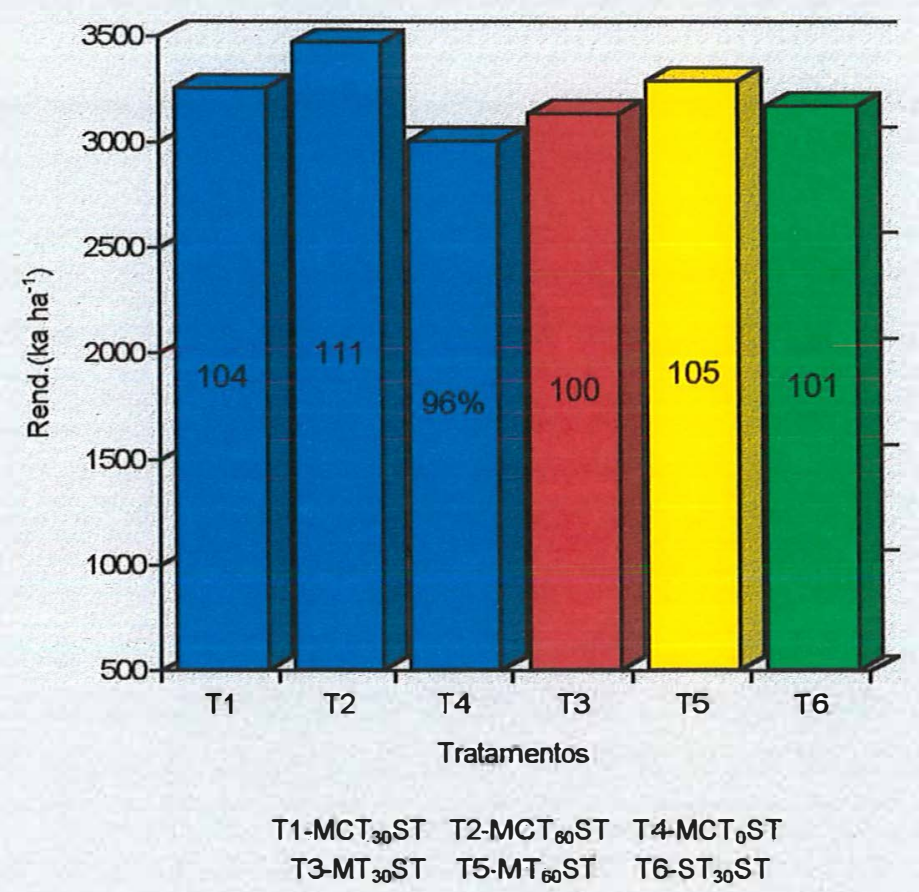

Figura 12. Rendimentos relativos de trigo, safra 1992.

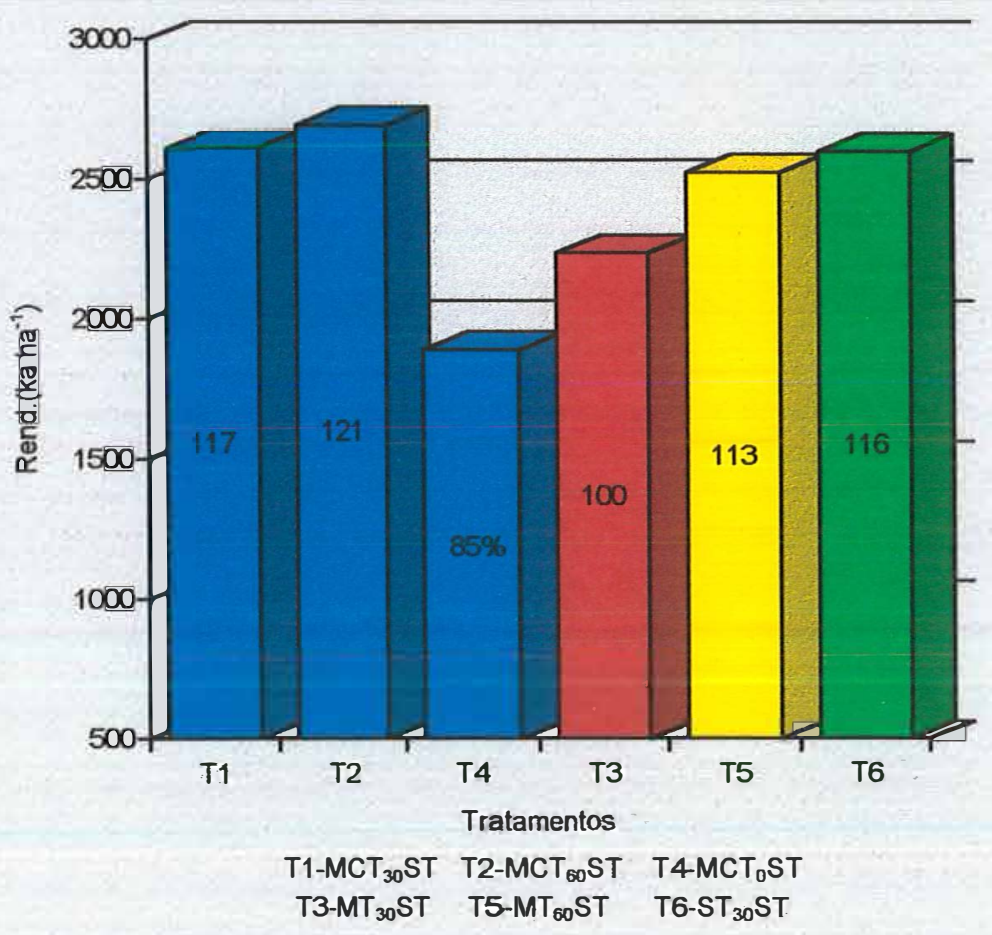

Figura 13. Rendimentos relativos de trigo, safra 1993. 


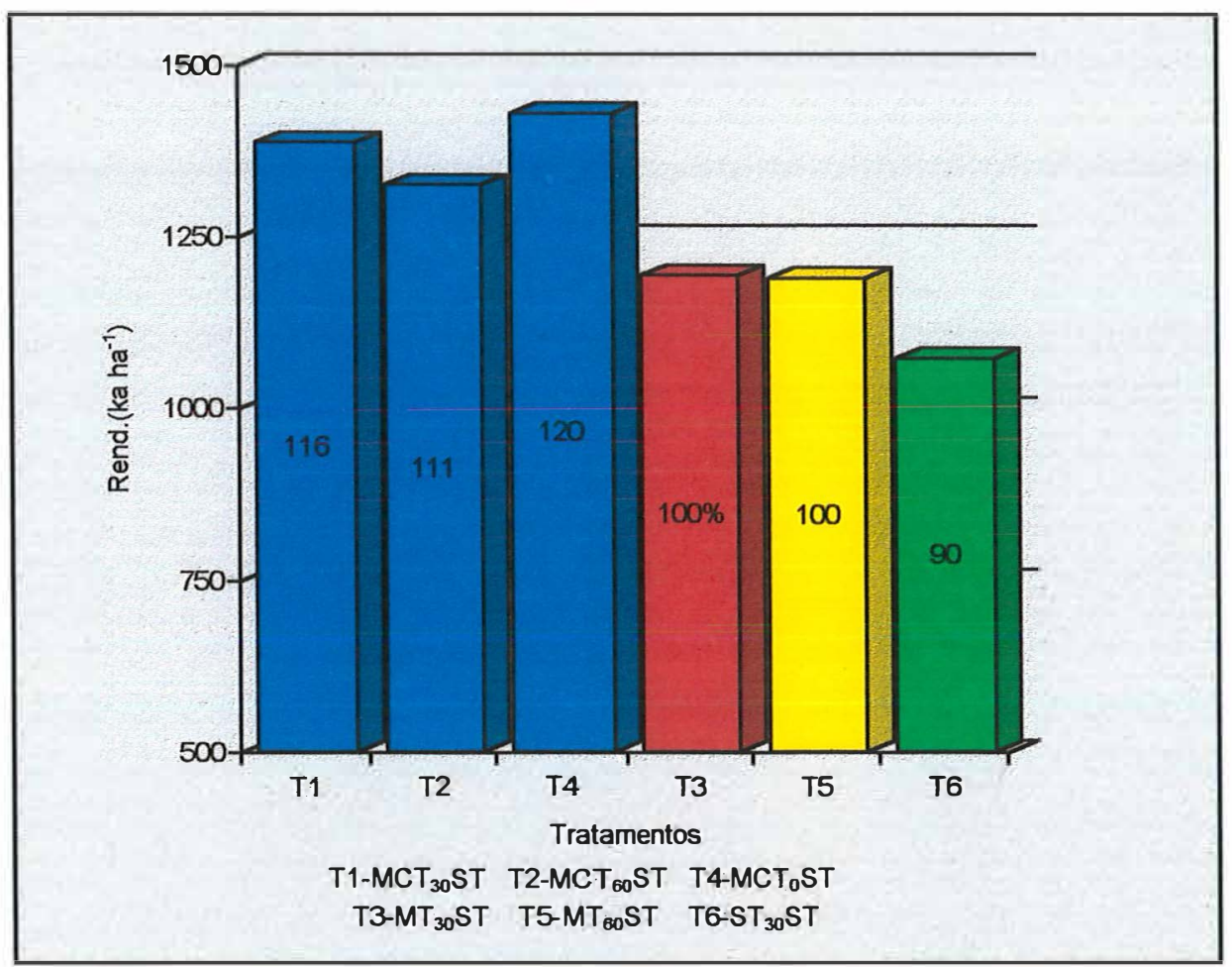

Figura 14. Rendimentos relativos de trigo, safra 1995.

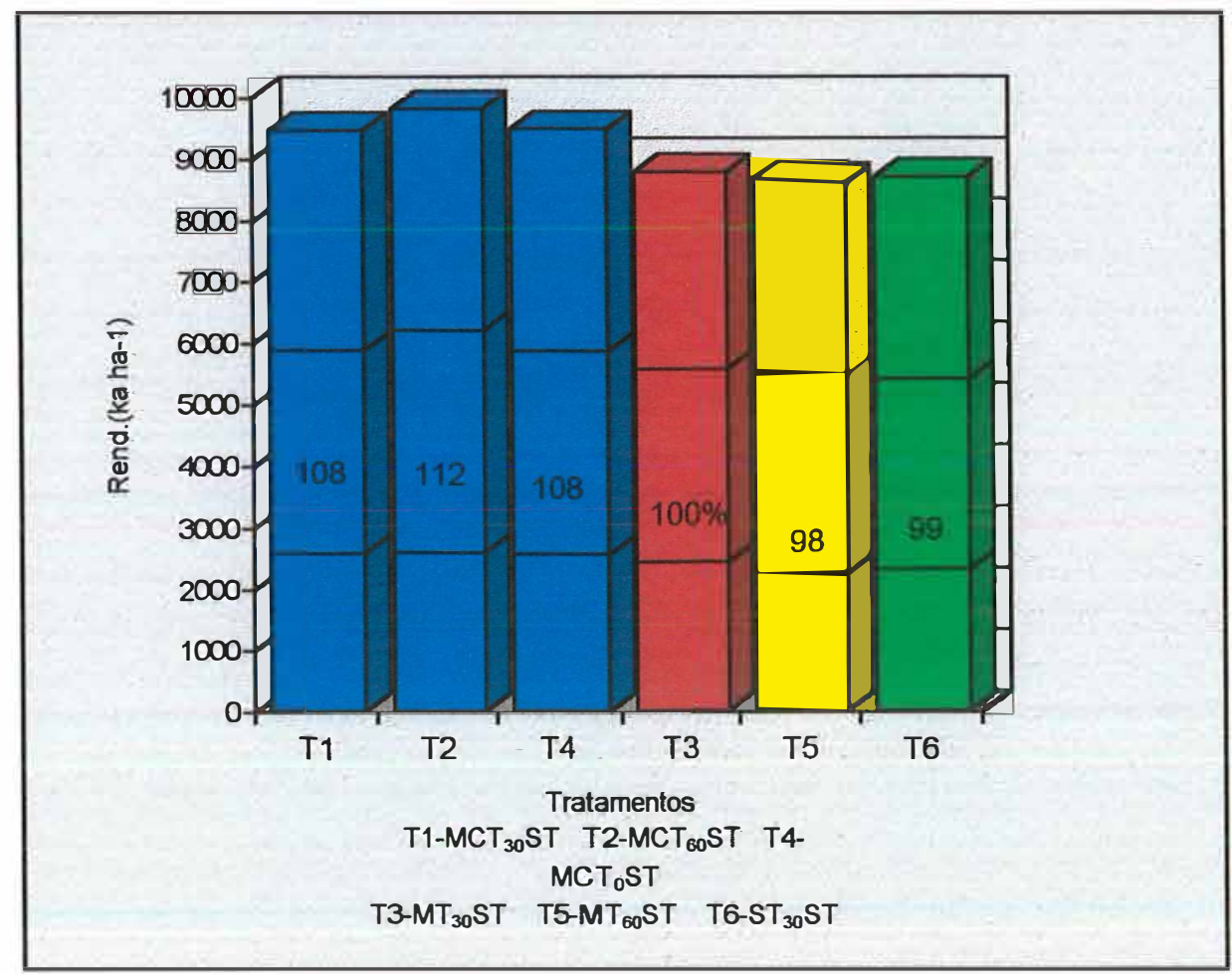

Figura 15. Rendimentos acumulados relativos de soja, safras 1992, 1994 e 1996. 


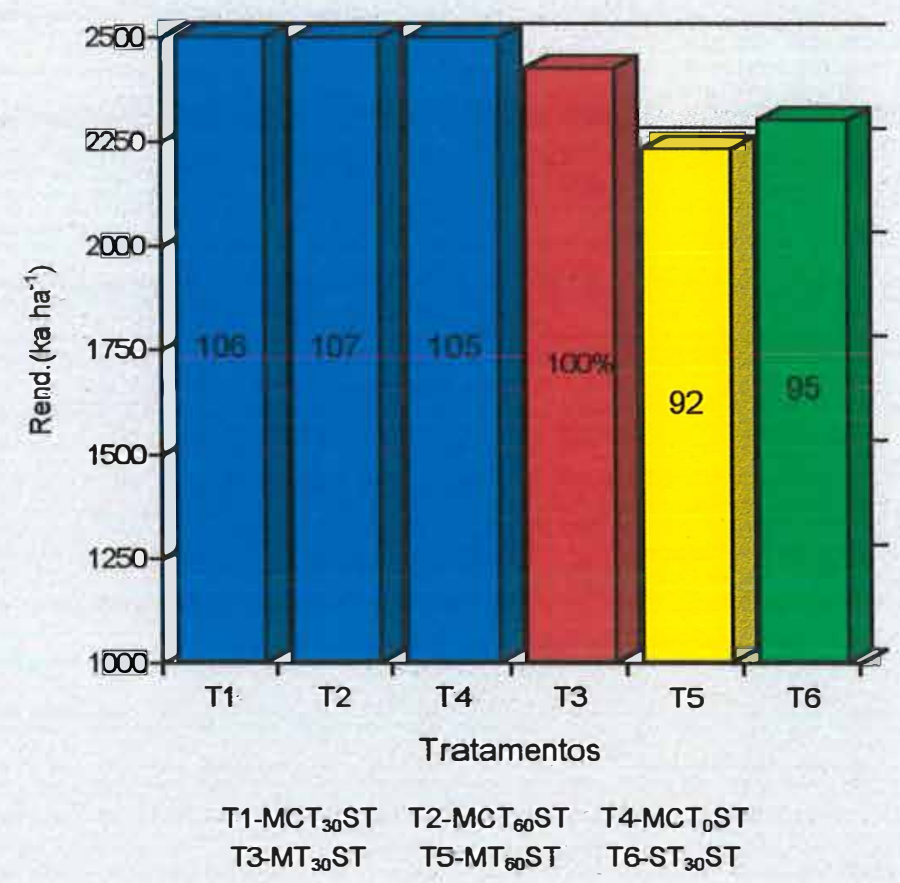

Figura 16. Rendimentos relativos de soja, safra 1992.

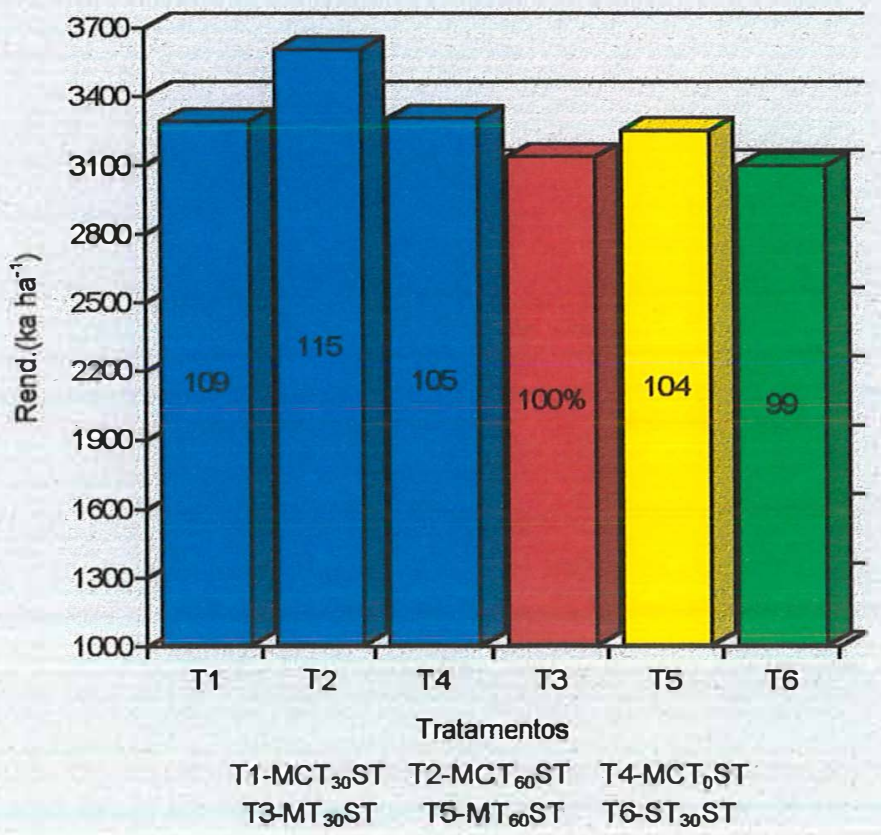

Figura 17. Rendimentos relativos de soja, safra 1994. 


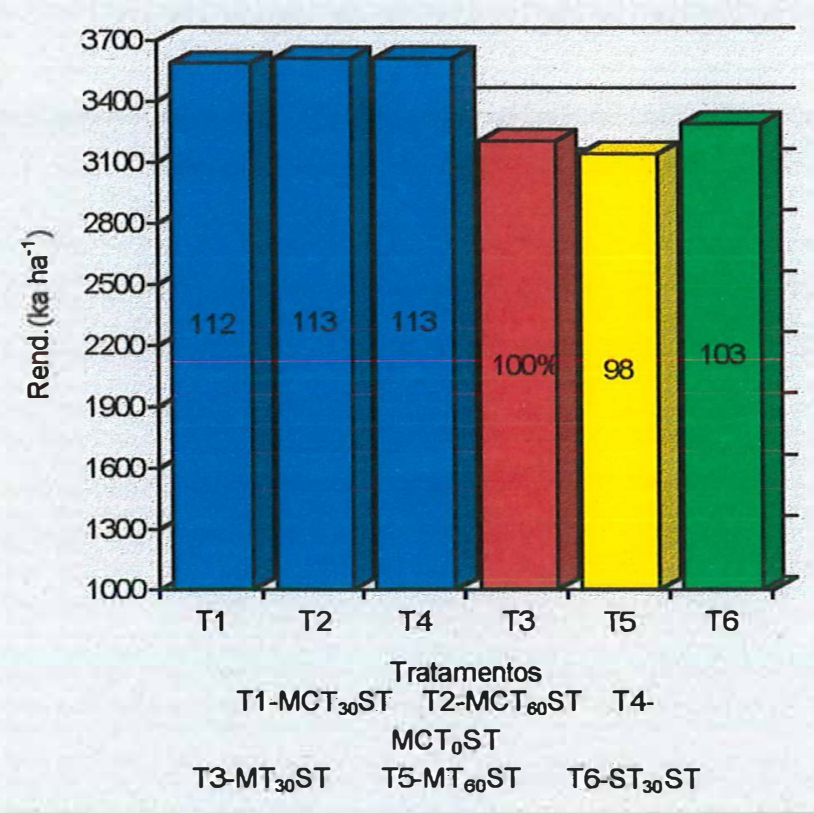

Figura 18. Rendimentos relativos de soja, safra 1996.

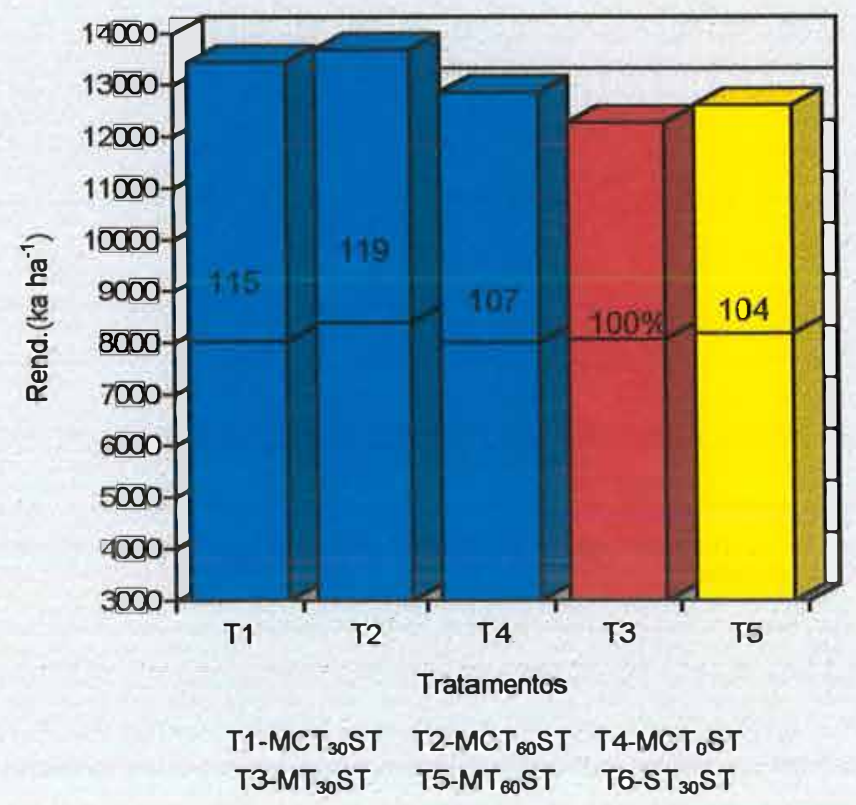

Figura 19. Rendimentos acumulados relativos de milho, safras 1993 e 19995. 


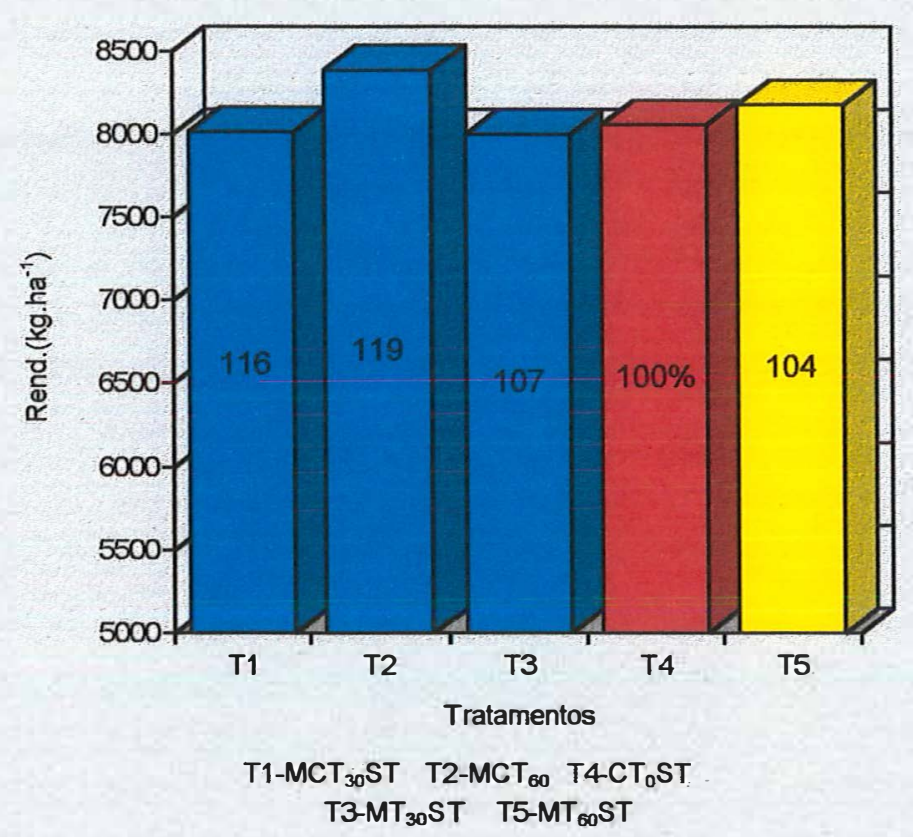

Figura 20. Rendimentos relativos de milho, safra 1993.

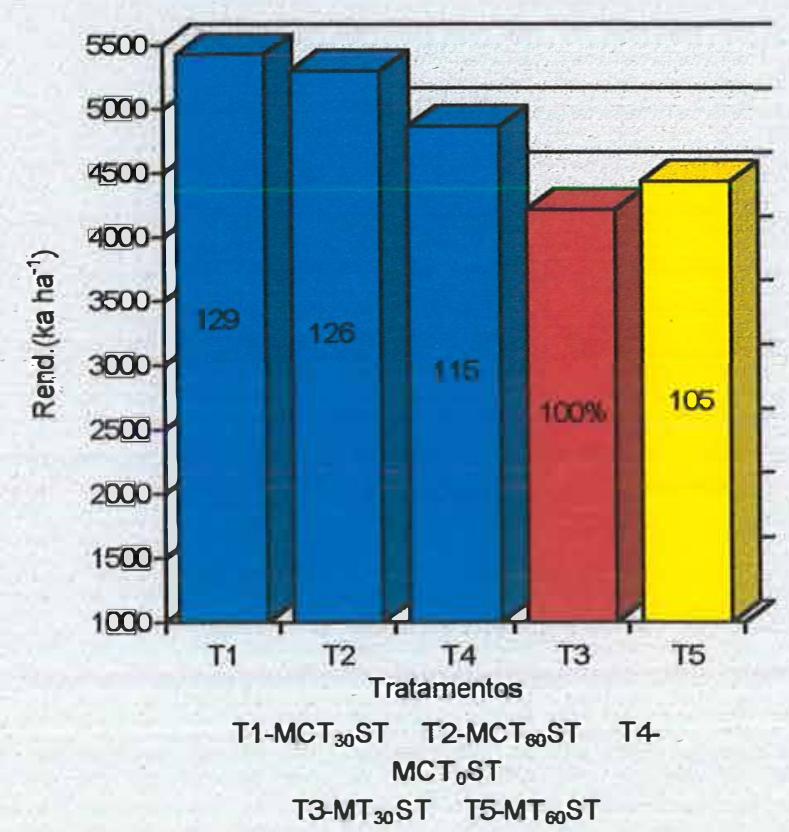

Figura 21. Rendimentos relativos de milho, safra 1995. 


\subsection{Resultados das análises química e física do solo}

Na tabela 6, comparando os resultados das análises de solo obtidas no início e final do experimento, verifica-se incremento nos teores de $\mathrm{P}, \mathrm{C}$, e $\mathrm{K}$, diminuição nos teores de Ca e manutenção dos níveis de $\mathrm{Mg}$. Tabela 6. Resultados das análises químicas do solo por tratamento, amostrado em 1996 e valores iniciais obtidos em 1991.

\begin{tabular}{|c|c|c|c|c|c|c|c|c|c|c|c|c|c|}
\hline \multirow[b]{2}{*}{ Trat. } & \multirow{2}{*}{$\begin{array}{c}\mathrm{cm} \\
\text { Prof. }\end{array}$} & \multirow{2}{*}{$\frac{\mathrm{CaCl}_{2}}{\mathrm{pH}}$} & \multirow{2}{*}{$\frac{\mu \mathrm{g} / \mathrm{cm}^{3}}{P}$} & \multicolumn{3}{|c|}{$\%$} & \multicolumn{7}{|c|}{$\mathrm{meq} / 100 \mathrm{ml}$ de solo } \\
\hline & & & & $\mathrm{C}$ & $\mathrm{Al}$ & V & $\mathrm{Al}$ & $\mathrm{H}+\mathrm{Al}$ & $\mathrm{Ca}$ & $\mathrm{Mg}$ & $\mathrm{K}$ & S & $\mathrm{T}$ \\
\hline \multirow[t]{2}{*}{$\mathrm{T}_{\mathrm{I}}$} & $0-10$ & 4.9 & 19.3 & 1.8 & 3.6 & 59 & 0.2 & 5.2 & 6.8 & 1.2 & 0.7 & 8.4 & 14 \\
\hline & $10-20$ & 5.1 & 8.3 & 1.4 & 1.8 & 63 & 0.1 & 4.6 & 6.8 & 1.1 & 0.5 & 8.4 & 13 \\
\hline \multirow[t]{2}{*}{$\mathrm{T}_{2}$} & $0-10$ & 5.2 & 29.1 & 1.8 & 0.6 & 66 & 0.0 & 4.4 & 7.4 & 1.3 & 1.1 & 9.7 & 14 \\
\hline & $0-20$ & 5.4 & 21.3 & 1.5 & 0.2 & 70 & 0.0 & 4.0 & 7.8 & 1.3 & 0.6 & 10 & 14 \\
\hline \multirow[t]{2}{*}{$\mathrm{T}_{3}$} & $0-10$ & 5.0 & 25.5 & 1.9 & 0.3 & 67 & 0.0 & 4.9 & 7.5 & 1.4 & 0.9 & 9.7 & 15 \\
\hline & $10-20$ & 5.3 & 10.4 & 1.5 & 0.2 & 69 & 0.0 & 4.3 & 7.6 & 1.3 & 0.7 & 9.6 & 14 \\
\hline \multirow[t]{2}{*}{$\mathrm{T}_{4}$} & $0-10$ & 5.0 & 21.1 & 1.8 & 0.8 & 65 & 0.0 & 4.8 & 7.2 & 1.3 & 0.8 & 9.3 & 14 \\
\hline & $10-20$ & 5.2 & 12.4 & 1.6 & 0.6 & 66 & 0.0 & 4.4 & 7.4 & 1.2 & 0.8 & 9.3 & 14 \\
\hline \multirow[t]{2}{*}{$\mathrm{T}_{5}$} & $0-10$ & 4.7 & 15.6 & 1.7 & 2.5 & 58 & 0.2 & 5.6 & 6.0 & 1.2 & 0.8 & 8.0 & 14 \\
\hline & $10-20$ & 5.0 & 7.6 & 1.5 & 0.4 & 66 & 0.0 & 4.4 & 6.9 & 1.2 & 0.7 & 8.8 & 13 \\
\hline \multirow[t]{2}{*}{$\mathrm{T}_{6}$} & $0-10$ & 4.9 & 16.1 & 1.7 & 0.5 & 62 & 0.0 & 5.0 & 6.3 & 1.3 & 0.7 & 8.2 & 13 \\
\hline & $10-20$ & 5.2 & 6.4 & 1.4 & 0.2 & 66 & 0.0 & 4.4 & 6.3 & 1.3 & 0.6 & 8.7 & 13 \\
\hline Valores & $0-10$ & 5.4 & 13.7 & 1.4 & 0.54 & 74 & 0.1 & 3.5 & 8.1 & 1.3 & 0.6 & 10.1 & 14 \\
\hline 1991 & $10-20$ & 5.5 & 8.8 & 1.1 & 0.23 & 74 & 0.0 & 3.3 & 7.4 & 1.3 & 0.5 & 9.2 & 12 \\
\hline
\end{tabular}




\subsubsection{Comportamento do $\mathrm{pH}$ do solo e saturação de bases (V\%)}

Os valores do $\mathrm{pH}$ apresentaram-se abaixo do nível médio inicial, em razão da liberação dos íons $\mathrm{H}^{+}$provenientes da matéria orgânica e, principalmente, devido às sucessivas adubações nitrogenadas com sulfato de amônio durante o período. Efeitos semelhantes no $\mathrm{pH}$ foram relatados por Oliveira (1994), trabalhando com adubos verdes e sulfato de amônio em algodão e por Oliveira \& Parizotto (1994), em trabalho desenvolvido com esterco de suíno e sulfato de amônio em milho e trigo, durante cinco anos.

Tabela 7. Resultados dos teores de $\mathrm{P}, \mathrm{K}, \mathrm{Ca}+\mathrm{Mg}$ e M.O. em duas profundidades.

\begin{tabular}{|c|c|c|c|c|c|}
\hline Trat. & $\begin{array}{c}\mathrm{P} \\
\mu \mathrm{g} / \mathrm{cm}^{3}\end{array}$ & $\frac{\mathrm{K}}{\mathrm{meq} / 100 \mathrm{ml} \text { de solo }}$ & $\begin{array}{c}\mathrm{Ca}+\mathrm{Mg} \\
\mathrm{meq} / 100 \mathrm{ml} \text { de solo }\end{array}$ & $\underset{\mathrm{CaCl}_{2}}{\mathrm{pH}}$ & $\begin{array}{c}\text { M.O. } \\
\%\end{array}$ \\
\hline \multicolumn{6}{|c|}{$0-10 \mathrm{~cm}$ de profundidade } \\
\hline $\mathrm{T} 1$ & 19,3 & 0,69 & 7,77 & 4,8 & 2,97 \\
\hline $\mathrm{T} 2$ & 29,1 & 1,06 a & 8,68 & 5,2 & 3,20 \\
\hline T3 & 25,5 & $0,85 \mathrm{ab}$ & 8,89 & 5,0 & 3,30 \\
\hline $\mathrm{T} 4$ & 21,1 & $0,84 \quad b$ & 8,47 & 5,0 & 3,08 \\
\hline T5 & 15,6 & $0,78 \mathrm{ab}$ & 7,21 & 4,7 & 3,03 \\
\hline T6 & 16,1 & $0,71 \quad b$ & 7,51 & 4,9 & 3,00 \\
\hline $\mathrm{F}^{1}$ & $\mathrm{~ns}^{2}$ & $*$ & $\mathrm{~ns}$ & $\mathrm{~ns}$ & ns \\
\hline $\mathrm{CV}$ & 43,10 & 22,29 & 20,69 & 6,83 & 13,50 \\
\hline \multicolumn{6}{|c|}{$10-20 \mathrm{~cm}$ de profundidade } \\
\hline $\mathrm{T} 1$ & 8,3 & $0,50 \quad b$ & 7,89 & 5,1 & 2,41 \\
\hline $\mathrm{T} 2$ & 15,0 & 0,87 a & 9,08 & 5,4 & 2,64 \\
\hline T3 & 10,4 & $0,65 \mathrm{ab}$ & 8,98 & 5,3 & 2,68 \\
\hline $\mathrm{T} 4$ & 12,4 & $0,62 \mathrm{ab}$ & 8,67 & 5,2 & 2,69 \\
\hline $\mathrm{T} 5$ & 7,7 & $0,66 \mathrm{ab}$ & 8,16 & 5,0 & 2,64 \\
\hline T6 & 6,4 & $0,56 \quad b$ & 8,16 & 5,2 & 2,44 \\
\hline $\mathrm{F}$ & ns & * & $\mathrm{ns}$ & ns & $\mathrm{ns}$ \\
\hline $\mathrm{CV}$ & $41,75^{3}$ & 25,84 & 16,00 & 7,07 & 11,93 \\
\hline
\end{tabular}

${ }^{1}$ Teste F. ${ }^{2}$ ns=não significativo.

* Valores seguidos pela mesma letra, na vertical, não diferem entre si pelo Teste de Duncan a $5 \%$ de probabilidade.

${ }^{3}$ De valores transformados pela função $x=1 y^{-1}$

Com relação a saturação de bases, ouve diminuição em função dos mesmos fatores que favoreceram a diminuição do pH. Entretanto, as amostragens efetuadas no linal do experimento, apresentaram percentuais adequados para as culturas estudadas. Esses resultados mostra que, devido 
a tendência de diminuição na saturação de bases em áreas de plantio direto, mesmo em solos eutróficos, implica na necessidade de monitoramento constante da área e possível necessidade de reposição do cálcio, através da aplicação sem incorporação de pequenas quantidades de calcário.

\subsubsection{Comportamento do Fósforo (P)}

Com relação ao fósforo $(\mathrm{P})$, devido à ocorrência de heterocedasticidade entre os tratamentos, seus dados foram transformados pela função $\mathrm{x}=1 \mathrm{y}^{-1}$. Desta feita, a grande variância nos teores de $\mathrm{P}$ obtidos por tratamento, bem como sua maior acumulação na camada superior do solo, foi função da baixa mobilidade e distribuição do elemento no perfil do solo, especialmente sob plantio direto (tabela 7). Dessa forma, há tendência de acumulação de $\mathrm{P}$ em sítios onde o elemento foi depositado pela semeadora. Muzilli (1981), Sá (1993) e Barber (1980) dão conta do comportamento de P no solo, condizentes com os resultados médios obtidos. $\mathrm{O}$ aumento nos teores de $\mathrm{P}$ em todos tratamentos era esperado, pois além da ciclagem do elemento pela mineralização dos resíduos vegetais, as quantidades do elementớ adicionadas ao solo, via fertilizantes, foram cerca de $50 \%$ superiores aos totais exportados pelos grãos (Malavolta, 1976) durante o quinquênio.

\subsubsection{Comportamento do Cálcio (Ca)}

A diminuição nos teores de cálcio é justificado pelo balanço negativo desse elemento no sistema, pois não houve entrada de Ca através de calagem; porém, o mesmo foi exportado através da produção de grãos (tabela 7). Oliveira \& Parizotto (1994), sem adição de calcário, também observaram diminuição nos teores de $\mathrm{Ca}$ do solo. Os mesmos autores afirmaram que, a redução de sua concentração no solo foi motivada pela exportação desse elemento via grãos de soja, milho e trigo. 


\subsubsection{Comportamento do Potássio (K)}

Com relação ao potássio, observa-se que, mesmo apresentando níveis iniciais elevados, o resultado da análise estatística mostrou diferença significativa entre alguns tratamentos; porém, de forma não consistente. Apesar das quantidades totais do elemento exportado pelos grãos (Malavolta, 1976) terem sido superiores aos totais adicionados pelos fertilizantes, constatou-se aumentos nos teores de $\mathrm{K}$ em todos tratamentos. É possível que o carreamento do elemento da subsuperfície até a superfície do solo, via raízes das culturas e do adubo verde, associado à mineralização dos resíduos vegetais, tenha contribuído para ciclagem do elemento e para o aumento de seus teores, durante o quinquênio avaliado (tabela 7).

\subsubsection{Comportamento da estabilidade dos agregados do solo}

Com referência à estabilidade dos agregados, dados apresentados na tabela 8 mostra que nos tratamentos $\mathrm{T}_{1}, \mathrm{~T}_{2}$ e $\mathrm{T}_{3}$, com crotalária júncea, na profundidade de $0-05 \mathrm{~cm}$, foram encontrados os maiores valores (g. $\mathrm{kg}^{-1}$ de solo) de agregados com tamanho médio geométrico (DMG) acima de $2 \mathrm{~mm}$. Entretanto, apenas houve diferença estatística entre o tratamento $T_{1}$ e $T_{6}$, conforme observado na tabela 8 . Para as demais profundidades não ocorreu a mesma tendência, não havendo diferenças estatísticas entre os sistemas. CAMPOS et al.(1995), trabalhando em um Latossolo Vermelho-Escuro, com diversos programas de rotação de culturas sob plantio direto e convencional, não encontraram diferença significativa na distribuição de DMG acima de $2 \mathrm{~mm}$, entre as rotações, dentro do mesmo sistema de preparo do solo. 
Tabela 8.Distribuição (g. $\left.\mathrm{kg}^{-1}\right)$ dos agregados com diâmetro médio geométrico $(\mathrm{DMG})>2 \mathrm{~mm}$ sob três profundidades - 1995/96.

\begin{tabular}{c|ccc}
\hline & \multicolumn{3}{c}{ Profundidade $(\mathrm{cm})$} \\
\hline Trat. & $0-05$ & $0-10$ & $10-20$ \\
\hline $\mathrm{T}_{1}$ & $8,83 \mathrm{a}$ & 8,82 & 8,92 \\
$\mathrm{~T}_{2}$ & $8,59 \mathrm{ab}$ & 8,97 & 8,93 \\
$\mathrm{~T}_{3}$ & $8,57 \mathrm{ab}$ & 9,06 & 9,17 \\
$\mathrm{~T}_{4}$ & $8,69 \mathrm{ab}$ & 8,91 & 9,17 \\
$\mathrm{~T}_{5}$ & $8,51 \mathrm{ab}$ & 8,91 & 8,84 \\
$\mathrm{~T}_{6}$ & $8,29 \mathrm{~b}$ & 8,85 & 9,06 \\
$\mathrm{~F}$ & $*$ & $\mathrm{~ns}$ & $\mathrm{~ns}$ \\
$\mathrm{CV} \%$ & 3,48 & 2,59 & 3,05 \\
\hline $\mathrm{C} / \mathrm{C}^{1}$ & 8,70 & 8,90 & 9,01 \\
\hline $\mathrm{S} / \mathrm{C}^{2}$ & 8,46 & 8,94 & 9,02 \\
\hline$*$ & Valores seguidos pela mesma letra, na vertical, não diferem entre si pelo \\
\multicolumn{2}{c}{ Teste de Duncan a 5\% de probabilidade. } \\
Valores médios dos tratamentos com crotalária. \\
2 Valores médios dos tratamentos sem crotalária.
\end{tabular}

Harris et al.(1966) relatam sobre a importância do consórcio de gramíneas e leguminosas para a melhoria da estruturação do solo. Possivelmente, a semelhança na estabilidade dos agregados tenha sido devido a que todas as sucessões empregadas foram compostas de gramíneas e leguminosas. Quando as comparações são realizadas para plantio direto, os benefícios inerentes ao sistema, tais como: permanência de cobertura do solo, equilíbrio na umidade do solo e, maior atividade microbiológica beneficiando a estrutura do solo, os resultados foram iguais para todos os tratamentos. Possivelmente, isso contribuiu para a não ocorrência de significância entre os tratamentos estudados.

\subsubsection{Comportamento da Matéria Orgânica do solo}

Os teores de Matéria Orgânica (M.O.) evoluíram do início ao final do período experimental, para todos os tratamentos; entretanto, entre os sistemas de produção não houve diferença estatística. Fatores como textura do solo, aumento da atividade microbiológica, presença de leguminosas aportando N, temperatura e umidade favoráveis (Fassbender \& 
Bornemisza, 1994 e Tisdale et al.,1985) contribuíram para redução do incremento e equilíbrio no teor de M.O., dentro dos níveis obtidos. Muzilli (1981) avaliando a acumulação da M.O. com diferentes sucessões de culturas envolvendo soja, trigo e milho, em plantio direto e convencional, obteve resultado semelhante, não encontrando diferença significativa entre as sucessões sob sistema de plantio direto.

A tabela 9 mostra os resultados do fracionamento da matéria orgânica, em g. $\mathrm{kg}^{-1}$ de solo, amostrada em cada parcela, na profundidade de 0-3 cm, representados pelos teores de ácido húmico e ácido fúlvico, e a razão entre eles. Os resultados das análises estatísticas não apresentaram diferenças significativas entre os sistemas. Possivelmente, os mesmos efeitos que agiram para a semelhança nos resultados de estabilidade dos agregados, contribuiram para a não observância de diferenças estatísticas nos resultados do fracionamento da matéria orgânica.

Tabela 9. Fracionamento da M.O. $\left(\mathrm{g} \mathrm{kg}^{-1}\right)$ do solo na profundidade de $0-3$ $\mathrm{cm}$.

\begin{tabular}{ccccccccc}
\hline Trat. & $\mathrm{Ct}^{1}$ & & \multicolumn{2}{c}{$\mathrm{NaOH}$} & & \multicolumn{2}{c}{ Pirofosfato de sódio } & Humina \\
& & $\mathrm{AH}^{2}$ & $\mathrm{AF}^{3}$ & $\mathrm{AH} / \mathrm{AF}$ & $\mathrm{AH}$ & $\mathrm{AF}$ & $\mathrm{AH} / \mathrm{AF}$ & \\
\hline $\mathrm{T}_{1}$ & 27 & 3,7 & 1,4 & 2,66 & 2,0 & 1,3 & 1,58 & 14 \\
$\mathrm{~T}_{2}$ & 31 & 4,5 & 1,4 & 3,40 & 2,2 & 1,3 & 1,69 & 17 \\
$\mathrm{~T}_{3}$ & 27 & 3,6 & 1,3 & 2,97 & 2,1 & 1,3 & 1,57 & 14 \\
$\mathrm{~T}_{4}$ & 28 & 3,6 & 1,4 & 2,79 & 2,1 & 1,3 & 1,60 & 16 \\
$\mathrm{~T}_{5}$ & 24 & 3,4 & 1,3 & 2,71 & 2,1 & 1,3 & 1,56 & 12 \\
$\mathrm{~T}_{6}$ & 28 & 3,9 & 1,4 & 2,73 & 2,1 & 1,4 & 1,51 & 15 \\
\hline & & $\mathrm{NS}^{4}$ & & & $\mathrm{NS}$ & & \\
\hline
\end{tabular}

${ }^{1}$ Carbono total - Wallkey-Black ${ }^{2}$ Ácido húmico $\quad{ }^{3}$ Ácido fúlvico

${ }^{4} \mathrm{NS}$ - Não significativo pelo Teste F.

Tanto pela extração por hidróxido de sódio, como por pirofosfato de sódio, os valores percentuais de ácido húmico superaram os de ácido fúlvico. As diferenças favoráveis para ácido húmico pode ser 
utilizada como uma característica para distinguir a condição físico-química e biológica favoráveis do solo. Fassbender \& Bornemisza (1994) relatam que os ácidos húmicos possuem maior peso molecular e tamanho de partículas, maior grau de polimerização, conferindo-lhes maior agregação e estabilidade. O contrário ocorre com os ácidos fúlvicos, pois são de cores mais claras, possuem maior reagibilidade e são mais laváveis no solo. Os autores ainda completam que, solos com relação ácido húmico.ácido fúlvico $^{-1}>1$ apresentam cores mais escuras, maior agregação e estabilidade, alta capacidade de troca catiônica e alto grau de retenção de água.

Pelos resultados obtidos, em regiões tropicais e subtropicais, em solos com cerca de $3 \%$, ou mais, de M.O, bianualmente explorados com culturas de grãos, o estabelecimento de um sistema de manejo que permite a permanente cobertura do solo e a manutenção dos níveis de M.O., demonstra-se adequado para a sustentabilidade de atividades agrícolas.

\subsection{Resultados de produção de matéria seca da crotalária júncea}

A crotalária foi semeada na segunda quinzena de fevereiro em todas as safras após milho, apresenta crescimento rápido e alto rendimento de matéria seca em curto período. Bulisani et al.(1987) afirmam que, para essa espécie, é comum a altura de 1,5 m de dossel, aos 60 dias de idade, para semeadura até meados de abril. Para as condições de solos corrigidos, cultivados com cereais ou Latossolo Roxo eutrófico, em semeaduras até final de fevereiro, a crotalária demonstra potencial para produção de 6-8 t.ha ${ }^{-1}$ de matéria seca aos 70 dias de idade, como demonstrou os resultados obtidos no presente trabalho e apresentados na tabela 10 . 
Tabela 10. Rendimento médio de matéria seca $\left(\mathrm{t} \mathrm{ha}^{-1}\right)$ e altura $(\mathrm{m})$ de crotalária júncea em sucessão a milho, em três anos agrícolas.

\begin{tabular}{cccccc}
\hline \hline Ref. & $91 / 92$ & $93 / 94$ & $95 / 96$ & Média & Total \\
\hline \hline Massa seca & $7,6^{1}$ & $6,8^{1}$ & $17.4^{2}$ & 10.6 & 31.6 \\
Altura & 1,70 & 1,60 & 1,95 & 1,75 & - \\
\hline
\end{tabular}

${ }^{1}$ Cortes aos 70 dias de idade. $\quad{ }^{2}$ Corte aos 120 dias de idade.

\subsection{Avaliação da população de plantas daninhas}

A população de plantas daninhas nos sistemas de sucessões de culturas, observada no período entre o manejo da crotalária e a semeadura do trigo que sucede o milho, é apresentado na tabela 11. As espécies encontradas foram: Amaranthus hybridus L. e A. viridis L. (caruru), Bidens pilosa (picão-preto), Richardia brasiliensis Gomez (poaia-branca), Brachiaria plantaginea Hitch (capim marmelada), Sonchus oleraceus L. (serralha) e principalmente Leonorus sibiricus L. (rubi). Nas parcelas com crotalária observou-se baixa incidência de plantas daninhas, sendo que a presença mais comum foi de caruru e poaia-branca., as quais apresentavam atrofiamento, estiolamento e estruturas florais precárias.

Tabela 11. Densidades de plantas daninhas amostradas na fase de présemeadura de trigo, safra 93/94.

\begin{tabular}{|c|c|c|c|c|c|c|c|}
\hline \multirow[t]{2}{*}{ Trat. } & \multicolumn{4}{|c|}{ Repetição } & \multirow{2}{*}{\multicolumn{3}{|c|}{$\sum$}} \\
\hline & A & B & C & D & & & \\
\hline $\mathrm{Tl}$ & $3^{1}$ & 2 & 4 & 1 & 3 & $a^{*}$ & $\mathrm{~A}^{* *}$ \\
\hline $\mathrm{T} 2$ & 5 & 3 & 4 & 2 & 4 & $\mathrm{~b}$ & $\mathrm{AB}$ \\
\hline T3 & 83 & 120 & 74 & 93 & 93 & $\mathrm{~b}$ & B \\
\hline $\mathrm{T} 4$ & 5 & 2 & 1 & 6 & 4 & $\mathrm{c}$ & $\mathrm{C}$ \\
\hline T5 & 70 & 180 & 135 & 120 & 126 & c & $\mathrm{C}$ \\
\hline T6 & 56 & 84 & 71 & 93 & 76 & c & $c$ \\
\hline
\end{tabular}

Valores seguidos pela mesma letra, nas colunas, não diferem entre si pelo Teste de Duncan em nível de $1 \%(* *)$ e $5 \%(*)$ de probabilidade.

CV: $39 \%$.

${ }^{1}$ Número de plantas por $\mathrm{m}^{2}$. 
Muitos são os dados de literatura mostrando a contribuição dos adubos verdes para controle de plantas daninhas, através de supressão ou efeitos alelopáticos. Possivelmente, devido à rápida germinação, emergência e sombreamento da superfície do solo, o efeito antagônico da crotalária júncea sobre as plantas daninhas dá-se, principalmente, pelo processo de supressão.

A tabela 12 refere aos resultados de contagens de plantas daninhas, realizadas no ano seguinte, na fase de pré-semeadura do trigo que antecede a soja, ou seja, um ano sem o emprego da crotalária na entressafra. As espécies de plantas daninhas presentes foram as mesmas da leitura realizada no ano anterior. Nos tratamentos $T_{1}, T_{2}$ e $T_{4}$, ano sem crotalária, houve aumento na população de plantas daninhas, sendo que os resultados estatísticos apresentaram diferenças significativas entre os tratamentos. $\mathrm{O}$ tratamento $\mathrm{T}_{6}$-monocultura de soja/trigo, comparado aos tratamentos $\mathrm{T}_{3}$ e $\mathrm{T}_{5}$-sucessão milho/trigo/soja, apresentaram números inferiores dessas plantas. Possivelmente, a ocorrência foi em razão do cultivar de soja apresentar porte alto e pela maior eficiência e efeito residual dos herbicidas utilizados na soja. O contrário ocorreu com a cultura do milho, onde normalmente verifica-se maior presença de plantas daninhas no sistema.

Tabela 12. Densidades de plantas daninhas amostradas na fase de présemeadura de trigo, safra 95/96.

\begin{tabular}{|c|c|c|c|c|c|}
\hline \multirow[t]{2}{*}{ Trat. } & \multicolumn{4}{|c|}{ Repetição } & \multirow[t]{2}{*}{$\Sigma$} \\
\hline & $\mathrm{A}$ & B & $\mathrm{C}$ & D & \\
\hline $\mathrm{Tl}$ & $56^{1}$ & 52 & 40 & 48 & $\mathrm{~d}^{*} \quad \mathrm{C}^{* *}$ \\
\hline $\mathrm{T} 2$ & 96 & 84 & 64 & 68 & $78 \quad \mathrm{c} \quad \mathrm{BC}$ \\
\hline $\mathrm{T} 3$ & 108 & 164 & 144 & 120 & $134 \mathrm{a} \quad \mathrm{A}$ \\
\hline $\mathrm{T} 4$ & 76 & 92 & 72 & 116 & 89 bc B \\
\hline T5 & 96 & 120 & 132 & 108 & $114 \mathrm{ab} \quad \mathrm{AB}$ \\
\hline T6 & 80 & 68 & 92 & 72 & $78 \quad \mathrm{c} \quad \mathrm{BC}$ \\
\hline
\end{tabular}

Valores seguidos pela mesma letra, na vertical, não diferem entre si pelo Teste de Duncan em nível de $1 \%\left({ }^{* *}\right)$ e $5 \%\left({ }^{*}\right)$ de probabilidade. CV: $19 \%$.

${ }^{1}$ Número de plantas por $\mathrm{m}^{2}$.

Os vários sistemas de produção testados, apresentaram-se em grupos diferenciados quanto ao número e espécies de plantas daninhas. 
Isso permitiu uma redução no uso de herbicidas e diminuição do banco de sementes de plantas no solo para alguns tratamentos. Nos tratamentos $T_{1}$, $\mathrm{T}_{2}$ e $\mathrm{T}_{4}$, nas safras de trigo, logo após a crotalária, foi desnecessário a utilização de herbicida de manejo em plantio direto, bem como a aplicação de 2,4-D no trigo. Para esses tratamentos, na primeira safra de soja, foi possível evitar a aplicação de triflularina + imazaquin, sendo que nas posteriores foi dispensado o herbicida triflularina.

A presença da crotalária júncea foi eficaz na diminuição da população de plantas daninhas no sistema, permanecendo seu efeito nas safras subsequentes. Observando as condições edafoclimáticas em que foi conduzido o presente trabalho, a introdução da crotalária júncea como adubo verde na entressafra contribuiu para a implantação de um programa de manejo integrado de plantas daninhas.

\subsection{Avaliação econômica dos sistemas de produção}

Os totais dos custos operacionais das safras estão apresentados nas tabelas de 1 a 12 (Apêndice I). A tabela 13 mostra as receitas líquidas por safra e as acumuladas no quinquênio, perfazendo um total de dez safras agrícolas. Nesse período, houve perda total de rendimentos de grãos por geada em duas safras de trigo. Assim, com o objetivo de não comprometer a avaliação econômica dos sistemas, optou-se por estender para todos os tratamentos o valor do prejuízo encontrado para trigo, no tratamento $T_{6}$, referente aos anos de perdas por geada. Dessa forma, a título de indenização de seguro agrícola, foram creditados para todos tratamentos nos anos de 1991 e 1994 , os valores de $\mathrm{R} \$ 201,00$ e $\mathrm{R} \$$ 212,00 , respectivamente. 
Tabela 13. Receita líquida auferida, para as culturas de trigo, soja e milho, durante período experimental - 1991 a 1996. (R\$).

\begin{tabular}{c|c|c|c|c|c|c|c|c|c|c|c}
\hline \hline & \multicolumn{2}{|c|}{$91 / 92$} & \multicolumn{2}{|c|}{$92 / 93$} & \multicolumn{2}{c|}{$93 / 94$} & \multicolumn{2}{c|}{$94 / 95$} & \multicolumn{2}{c|}{$1995 / 96$} & Rend. \\
\hline \hline Trat & Trigo & Soja & Trigo & Milho & Trigo & Soja & Trigo & Milho & Trigo & Soja & Acumulado \\
\hline \hline T1 & -46 & 273 & 255 & 456 & 118 & 417 & - & 283 & 6 & 560 & 2.322 \\
T2 & -70 & 276 & 263 & 495 & 107 & 474 & -24 & 270 & -30 & 565 & 2.326 \\
T3 & - & 228 & 237 & 460 & 106 & 374 & - & 124 & 16 & 451 & 1996 \\
T4 & -17 & 269 & 247 & 454 & 19 & 419 & 29 & 219 & 43 & 566 & 2.248 \\
T5 & -24 & 192 & 236 & 467 & 150 & 396 & -24 & 150 & 9 & 438 & 1.990 \\
\hline Trat & Trigo & Soja & Trigo & Soja & Trigo & Soja & Trigo & Soja & Trigo & Soja & \\
\hline \hline T6 & - & 205 & 242 & 239 & 161 & 367 & - & 304 & -6 & 479 & 1.991 \\
\hline \hline
\end{tabular}

Não houve diferença significativa entre os tratamentos pelo Teste $\mathrm{F}$ a $5 \%$ de probabilidade. CV: $23 \%$.

As dez safras de cada sistema ou tratamento proposto foram avaliadas de forma conjunta. Assim, considerando cada safra uma repetição, foi obtido a receita líquida acumulada ao longo de cinco anos. Esses valores apresentam desvio padrão intraespecífico e interespecífico elevado. Isto ocorreu em consequência das adversidades agroclimáticas, interferindo no rendimento de grãos e na estabilidade da receita líquida, principalmente para trigo, devido à sua maior susceptibilidade. Pela análise estatística efetuada não houve diferença significativa entre os tratamentos.

Analisando os valores acumulados de receitas líquidas por tratamento, os tratamentos $\mathrm{T}_{1}, \mathrm{~T}_{2}$ e $\mathrm{T}_{4}$ (com crotalária) acumularam, no quinquênio, valores médios de $\mathrm{R} \$ 2.299,00$, enquanto que os tratamentos $\mathrm{T}_{3}$ e $\mathrm{T}_{4}$ (sem crotalária) acumularam valores médios de $\mathrm{R} \$ 1.978,00$.

\subsubsection{Desempenho econômico da cultura do trigo}

Na safra de trigo do ano agrícola 91/92, os tratamentos $T_{1}$ e $\mathrm{T}_{2}$ apresentaram receitas líquidas negativas maiores que os demais devido a 
perda total da produção e por estarem neles embutidos os custos totais de implantação da crotalária. Já o tratamento $T_{4}$, teve sua receita líquida favorecida pela retenção de custos pela não aplicação de nitrogênio em cobertura. No ano de 1993, o tratamento $T_{4}$ teve a produção deprimida devido a ausência da adubação de cobertura, sendo que a receita líquida aproximou-se do nível ponto de equilíbrio econômico.

Considerando os riscos da cultura do trigo, tanto em nível de produção como nos preços de mercado, é sensato racionalizar a adubação com N-mineral, visando maximizar o lucro a auferir. Analisando os tratamentos $T_{1}, T_{2}$ e $T_{4}$, nos quais trigo foi precedido de crotalária com 30, 60 e $0 \mathrm{~kg} \mathrm{ha}^{-1}$ de $\mathrm{N}$, respectivamente, a tabela 14 mostra que níveis intermediários, próximos a $30 \mathrm{~kg}$. $\mathrm{ha}^{-1}$ de $\mathrm{N}$, favoreceu a expectativa de maior retorno econômico do investimento. Entretanto, em anos de adversidades climáticas, como geadas e déficit hídrico severo, como ocorrido nas condições do presente trabalho, o investimento com $\mathrm{N}$ mineral em cobertura pode propiciar retorno negativo.

Tabela 14. Níveis de $\mathrm{N}$ em cobertura em trigo e retorno financeiro por unidade aplicada.

\begin{tabular}{c|c|c|c|c}
\hline Safra & $\begin{array}{c}\text { Nível } \\
\mathrm{N}\end{array}$ & $\begin{array}{c}\text { Acréscimo } \\
\text { grãos }\end{array}$ & $\begin{array}{c}\text { Conversão } \\
\text { kg grãos/kg N }\end{array}$ & $\begin{array}{c}\text { Retorno R\$ } \\
\text { kg grãos/kg N }\end{array}$ \\
\hline \multirow{2}{*}{$92 / 93$} & $\mathrm{~T}_{1}-30$ & 250 & 8,33 & 1,08 \\
& $\mathrm{~T}_{2}-60$ & 446 & 7,77 & 1,00 \\
\hline \multirow{2}{*}{$94 / 95$} & $\mathrm{~T}_{1}-30$ & 721 & 24,03 & 3,10 \\
& & & 13,40 & 1,73 \\
\hline
\end{tabular}

\subsubsection{Desempenho econômico da cultura da soja}

A soja foi a cultura que manteve maior equilíbrio econômico entre os tratamentos, sendo que as receitas líquidas aumentaram gradativamente a cada ano. Na safra de 91/92, comparativamente aos demais anos, a média da receita líquida dos tratamentos de soja foi inferior, em decorrência da menor produção de grãos ocasionado pelo 
défice hídrico na fase de florescimento, frutificação e enchimento dos grãos.

Observa-se que em todas as safras de soja os tratamentos $T_{1}$, $\mathrm{T}_{2}$ e $\mathrm{T}_{4}$, nos quais a crotalária esteve presente, tiveram suas receitas líquidas superiores aos demais tratamentos. Além do benefício da crotalária no aumento dos rendimentos de grãos, esses tratamentos também tiveram as receitas líquidas influenciadas pela redução do uso do herbicida triflularina e capinas em soja.

\subsubsection{Desempenho econômico da cultura do milho}

Após a cultura do trigo, a cultura do milho foi a que demonstrou maior instabilidade na receita líquida. Isto, por apresentar custos operacionais mais elevados, além de ser mais sensível às condições climáticas adversas quando comparado com cultura da soja. Nos tratamentos, onde a crotalária júncea esteve presente, os ganhos nas receitas líquidas foram maiores para milho. Tais vantagens, deveram-se mais ao aumento das receitas brutas oriundas do incremento da produção de grãos promovido pela adubação verde do que pela redução do uso de insumos.

\subsubsection{Economia pela redução do uso de herbicidas}

As despesas com herbicidas por safra, conforme apresentado na tabela 15, mostra que o "sistema-crotalária" permitiu a redução dos custos com esse insumo, para 50, 43 e 82\%, em trigo, soja e milho, respectivamente, sendo que o sistema trigo/soja absorveu o maior custo acumulado com herbicidas. A última coluna mostra o total das despesas com herbicidas acumulado durante o período experimental, bem como os valores percentuais relativos entre os tratamentos. Observa-se que os 
sistemas de produção envolvendo crotalária apresentaram os menores custos diretos com herbicidas.

Tabela 15. Total dos custos com controle de plantas daninhas e valores comparativos

\begin{tabular}{c|lc|lc|cccc}
\hline Trat & \multicolumn{2}{|c|}{ Trigo } & \multicolumn{2}{c|}{ Soja } & \multicolumn{2}{c}{ Milho } & \multicolumn{2}{c}{ Total acumulado } \\
& $\mathrm{R} \$$ & $\%$ & $\mathrm{R} \$$ & $\%$ & $\mathrm{R} \$$ & $\%$ & $\mathrm{R} \$$ & $\%$ \\
\hline $\mathrm{T}_{1}$ & $63,24^{1}$ & 50 & $72,71^{1}$ & 43 & $61,41^{1}$ & 82 & 197,36 & 48 \\
$\mathrm{~T}_{2}$ & 63,24 & 50 & 72,71 & 43 & 61,41 & 82 & 197,36 & 48 \\
$\mathrm{~T}_{3}$ & 126,48 & 100 & 170,01 & 100 & 74,63 & 100 & 371,12 & 100 \\
$\mathrm{~T}_{4}$ & 63,24 & 50 & 72,71 & 43 & 61,41 & 82 & 197,36 & 48 \\
$\mathrm{~T}_{5}$ & 126,48 & 100 & 170,01 & 100 & 74,63 & 100 & 371,12 & 100 \\
$\mathrm{~T}_{6}$ & 126,48 & 100 & 253,60 & - & - & - & 458,11 & 138 \\
\hline
\end{tabular}

${ }^{1}$ Soma de valores por cultura durante o quinquênio experimental.

\subsubsection{Balanço econômico dos sistemas de produção}

A relação benefício/custo demonstrou a tendência de taxas de retorno favoráveis para os tratamentos envolvendo o uso da crotalária. Isto evidenciou a necessidade de tratar a adubação verde como investimento, apesar de seu custo inicial de implantação.

Tabela 16. Balanço econômico dos resultados acumulados-final do período.

\begin{tabular}{c|c|c|c|c|c|c}
\hline Especificação & $\mathrm{T}_{1}$ & $\mathrm{~T}_{2}$ & $\mathrm{~T}_{3}$ & $\mathrm{~T}_{4}$ & $\mathrm{~T}_{5}$ & $\mathrm{~T}_{6}$ \\
\hline Custos variáveis & 2.540 & 2.660 & 2.469 & 2.413 & 2.578 & 2.113 \\
Receita bruta & 4.813 & 4.939 & 4.439 & 4.621 & 4.511 & 4.026 \\
Receita líquida & 2.322 & 2.326 & 2.056 & 2.248 & 1.840 & 1991 \\
\hline Benefício/Custo & 1,90 & 1,86 & 1,80 & 1,92 & 1,75 & 1,91 \\
\hline
\end{tabular}

Analisando a tabela 16, o valor médio da relação benefício/custo dos três sistemas de produção com crotalária foram superiores à média da relação dos três sistemas onde a essa leguminosa esteve ausente. Em função dos crescentes problemas agronômicos em sistemas de monoculturas, faz-se necessário a acumulação de mais dados 
para melhor avaliar o sistema "trigo-soja", principalmente oriundos de experimentos de longa duração.

O conhecimento desses resultados financeiros por parte dos usuários diretos da tecnologia agropecuária e assistência técnica pode tornar mais atrativa a adoção da adubação verde com crotalária na entressafra, principalmente em sistema de plantio direto.

\subsection{Balanço energético}

Durante o período experimental de cinco anos agrícolas, todas as operações mecanizadas e manuais, locação de insumos foram registradas e transformadas em valores energéticos na unidade de caloria. Nas tabelas de 14 a 25, do Apêndice, constata-se os valores energéticos das operações e insumos, rendimentos de grãos por tratamento e por safra, bem como a eficiência energética e eficiência cultural.

Os resultados de eficiência energética, podem ser observados na tabela 17.

Tabela 17. Eficiência energética (EE) por safra obtida no ciclo experimental.

\begin{tabular}{|c|c|c|c|c|c|c|c|c|c|c|c|c|}
\hline & \multicolumn{2}{|c|}{$91 / 92$} & \multicolumn{2}{|c|}{$92 / 93$} & \multicolumn{2}{|c|}{$93 / 94$} & \multicolumn{2}{|c|}{$94 / 95$} & \multicolumn{2}{|c|}{$1995 / 96$} & \multirow{2}{*}{\multicolumn{2}{|c|}{$\begin{array}{c}\text { EE } \\
\text { Média }\end{array}$}} \\
\hline Trat & Trigo & Soja & Trigo & Milho & Trigo & Soja & Trigo & Milho & Trigo & Soja & & \\
\hline $\mathrm{T} 1$ & - & 10,06 & 6,71 & 10,59 & 5,87 & 12,18 & - & 7,03 & 3,12 & 13,28 & $8,61 \mathrm{ab}$ & $A B$ \\
\hline T2 & - & 10,14 & 5,59 & 11,08 & 4,64 & 13,35 & - & 6,86 & 2,28 & 13,37 & 8,41 abc & $\mathrm{AB}$ \\
\hline T3 & - & 8,67 & 6,47 & 10,65 & 4,55 & 11,54 & - & 5,45 & 2,46 & 11,67 & 7,68 & $A B$ \\
\hline T4 & - & 9,99 & 8,64 & 10,57 & 6,14 & 12,24 & - & 6,29 & 4,65 & 13,38 & $8,98 \mathrm{a}$ & A \\
\hline $\mathrm{T} 5$ & - & 7,98 & 5,30 & 10,81 & 4,02 & 11,96 & - & 5,74 & 1,93 & 11,26 & 7,38 & B \\
\hline Trat & Trigo & Soja & Trigo & Soja & Trigo & Soja & Trigo & Soja & Trigo & Soja & & \\
\hline T6 & & 8,23 & 6,54 & 9,48 & 5,29 & 11,39 & & 10,61 & 2,21 & 12,11 & 8,23 abc & $A B$ \\
\hline
\end{tabular}

Valores seguidos da mesma letra, na coluna, não diferem entre si pelo Teste de Duncan a 5\% e $1 \%$ de probabilidade. CV: $12 \%$. 
A Eficiência Energética dos sistemas demonstra ser dependente da produtividade dos cultivares e do rendimento de grãos obtidos. Em função das adversidades climáticas ocorridas durante o período experimental, observa-se a tendência de apresentar maior eficiência os sistemas que receberam menores quantidades de insumos, principalmente adubos minerais nitrogenados.

A tabela 18 apresenta os resultados de eficiência cultural acompanhadas dos resultados das análises estatísticas.

Tabela 18. Elíciência cultural (EC) por safra obtida durante o ciclo experimental.

\begin{tabular}{|c|c|c|c|c|c|c|c|c|c|c|c|}
\hline & \multicolumn{2}{|c|}{$91 / 92$} & \multicolumn{2}{|c|}{$92 / 93$} & \multicolumn{2}{|c|}{ 93/94 } & \multicolumn{2}{|c|}{$94 / 95$} & \multicolumn{2}{|c|}{$1995 / 96$} & EC \\
\hline Trat & Trigo & Soja & Trigo & Milho & Trigo & Soja & Trigo & Milho & Trigo & Soja & Média \\
\hline $\mathrm{T} 1$ & - & 2,50 & 2,04 & 3,04 & 1,79 & 3,03 & - & 2,02 & 0,95 & 3,30 & $2,33 \mathrm{ab} \quad \mathrm{AB}$ \\
\hline $\mathrm{T} 2$ & - & 2,52 & 1,70 & 3,18 & 1,41 & 3,32 & - & 1,97 & 0,70 & 3,32 & 2,27 abc $A B$ \\
\hline $\mathrm{T} 3$ & - & 2,16 & 1,97 & 3,06 & 1,39 & 2,87 & - & 1,57 & 0,75 & 2,93 & 2,09 bc $\mathrm{AB}$ \\
\hline T4 & - & 2,48 & 2,63 & 3,04 & 1,87 & 3,04 & - & 1,81 & 1,41 & 3,33 & $2,45 \mathrm{a}$ \\
\hline T5 & - & 1,98 & 1,61 & 3,10 & 1,22 & 2,97 & - & 1,65 & 0,59 & 2,88 & 2,00 \\
\hline Trat & Trigo & Soja & Trigo & Soja & Trigo & Soja & Trigo & Soja & Trigo & Soja & \\
\hline T6 & - & 2,05 & 1,99 & 2,36 & 1,61 & 2,83 & - & 2,64 & 0,67 & 3,01 & 2,15 bc $A B$ \\
\hline
\end{tabular}

Valores seguidos da mesma letra, na vertical, não diferem entre si pelo Teste de Duncan a $5 \%$ e $1 \%$ de probabilidade.

CV: $11 \%$.

\subsubsection{Balanço energético da cultura da soja}

A soja apresentou a menor variação de eficiência energética (EE) e de eficiência cultural (EC) entre os tratamentos. Isto pode ser explicado pela sua não dependência de adubação mineral nitrogenada; por permitir que parte de seu controle de pragas seja realizado por meios biológicos através de baculovirus; por ser uma cultura mais rústica que as demais, sofrendo menos os estresses ambientais. 


\subsubsection{Balanço energético da cultura do milho}

O milho também apresentou EE e EC equilibradas, isso em razão de ter sido alocado os mesmos níveis $\left(90 \mathrm{~kg} \cdot \mathrm{ha}^{-1}\right)$ de adubos nitrogenados em cobertura para todos tratamentos. No ano de 1995, os índices de ECs mais elevados foram as dos tratamentos $T_{1}, T_{2}$ e $T_{4}$, os quais constam adubação verde com crotalária no sistema.

Contudo, a cultura do milho de alta produtividade, onde normalmente emprega-se altos níveis de $\mathrm{N}$-mineral, quando não irrigado, pode ter seus níveis de eficiência energética e de eficiência cultural severamente reduzidos por condições climáticas adversas. O presente trabalho mostrou a redução nesses índices pelo défice hídrico, ocorrido no ano agrícola 1995.

\subsubsection{Balanço energético da cultura do trigo}

$\mathrm{O}$ trigo apresentou os menores índices de EE e EC, comparado com soja e milho, devido ao risco de resposta aos insumos empregados, associado à alta susceptibilidade às condições climáticas adversas. Observa-se que, mesmo o trigo assumindo o custo energético da introdução da crotalária, os tratamentos $T_{1}$ e $T_{4}$ apresentaram maior EC, em todos os anos, inclusive quando comparada com a monocultura de trigo/soja, no tratamento $T_{6}$. Resultado semelhante obteve Santos (1992), onde a razão entre o rendimentos de grãos e o total de energia demandada no processso produtivo de trigo em monocultura, foi inferior comparado com trigo em sistemas de rotações de culturas.

$\mathrm{O}$ tratamento $\mathrm{T}_{2}$ e $\mathrm{T}_{5}$, onde foi aplicado $60 \mathrm{~kg} \mathrm{ha}^{-1} \mathrm{de}$ nitrogênio em cobertura, inclusive onde apresentaram maiores rendimentos de grãos de trigo, resultaram em menores EEs e ECs. Assim, pode-se inferir que doses maiores de $\mathrm{N}$ não contribuem para a elevação desses índices. $\mathrm{O}$ alto custo energético para produção do nitrogênio mineral afeta 
o balanço energético do sistema, mesmo que resulte em aumento de rendimento de grãos da cultura. Segundo Felipe Júnior et al.(1984), em condições das indústrias nacionais, há um dispêndio de $14.930 \mathrm{kcal} . \mathrm{kg}^{-1} \mathrm{de}$ nitrogênio mineral produzido.

Com relação a eficiência energética, o resultado da análise estatística destaca o tratamento $T_{4}$ - crotalária - sem $\mathrm{N}$ em cobertura no trigo. O mesmo foi desfavorável ao tratamento $T_{5}$ - sem crotalária - com 60 kg.ha ${ }^{-1}$ de $\mathrm{N}$ em cobertura no trigo. Os dados evidenciaram que a adubação verde, para todos tratamentos, contribuiu para o aumento da eficiência energética do sistema.

\subsubsection{Balanço energético dos sistemas de produção}

Analisando os sistemas de produção, conforme última coluna da tabela 17 e da tabela 18, observa-se que, os tratamentos que receberam adubação verde na entressafra, embora adicionados os custos energéticos de implantação e manejo da crotalária, apresentaram EE média e EC média superiores. Para EE, houve diferença estatística entre os tratamentos $T_{1}(8,61)$ e $T_{5}(7,38)$ e os tratamentos $T_{4}(8,98)$ e $T_{3}(7,68)$, $\mathrm{T}_{5}(7,38)$. Para EC, houve diferença entre o $\mathrm{T}_{1}(2,33)$ e $\mathrm{T}_{5}(2,00)$ e entre os tratamentos $\mathrm{T}_{4}(2,45)$ e $\mathrm{T}_{3}(2,09), \mathrm{T}_{5}(2,00), \mathrm{T}_{6}(2,15)$.

Para o modelo de produção agrícola adotado, a alta produtividade demonstra ser dependente da alocação de insumos de alto custo energético. Entretanto, para trigo, no sistema proposto no tratamento $\mathrm{T}_{1}$, é possível - com doses intermediárias de $\mathrm{N}$ em cobertura $\left(30 \mathrm{~kg} \mathrm{ha}^{-1}\right)$, com o emprego de rotação de culturas; plantio direto e adubação verde obter alta produtividade, acompanhada de um balanço energético mais equilibrado, resultando em maior sustentabilidade ao sistema de produção agrícola. 


\section{CONCLUSÕES}

A análise e interpretação dos resultados obtidos permitem concluir que: 1. A introdução da crotalária como cobertura do solo no período de entressafra, não interfere na época preferencial de semeadura das culturas comerciais. 2. O nitrogênio fixado simbioticamente, e liberado, pela crotalária no primeiro ano de sua implantação, não é suficiente para satisfazer as necessidades desse elemento por gramíneas que a sucede. 3. O custo de implantação da adubação verde proposta é diluído no decorrer dos anos, sendo que os benefícios são crescentes ao longo dos anos, traduzindo em maior rendimento econômico ao sistema. 4. A utilização da crotalária como adubação verde contribui para a sustentabilidade do agroecossistema. 5. O uso do balanço energético na avaliação de sistemas de produção é fundamental para a evidência de aspectos relativos à sustentabilidade não detectados pelo desempenho agronômico e econômico de culturas. 

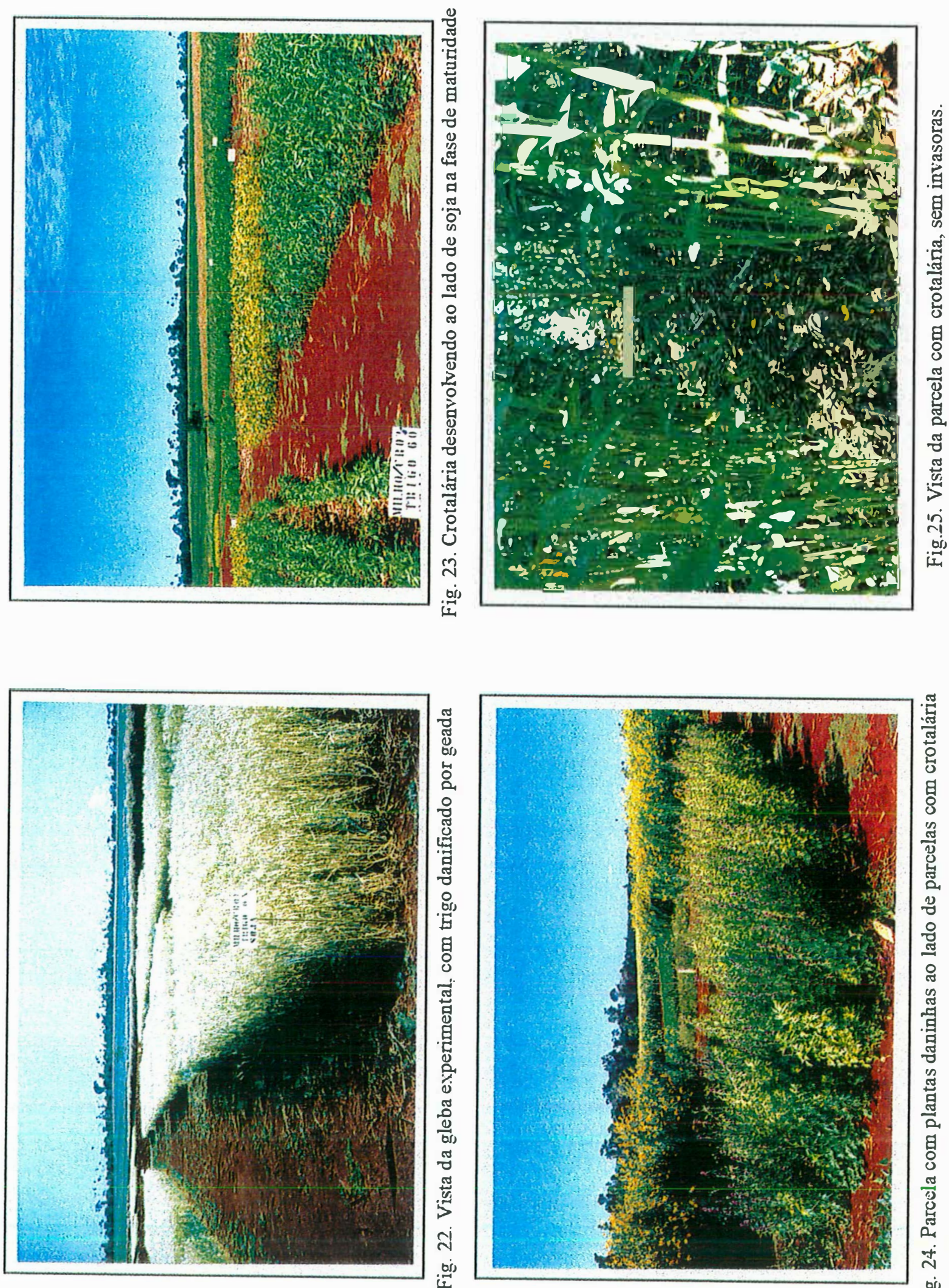

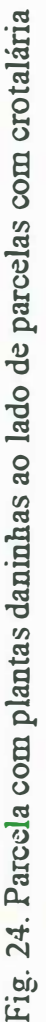




\section{REFERÊNCIAS BIBLIOGRÁFICAS}

ALBUQUERQUE, J.A.; REINERT, D.J.; FIORRIN, J.E.; RUEDELL, J.; PETRERE, C.; FONTINELLI, F. Rotação de culturas e sistemas de manejo do solo: efeito sobre a forma da estrutura do solo ao final de sete anos. Revista Brasileira Ciência Solo, v. 19, p. 115-9, 1995.

ALLARD, R.W. Principles of plant breeding. New York: Wiley Sons, 1960. 485 p.

ALMEIDA, F.S. A alelopatia e as plantas. Londrina: IAPAR, 1988. 60p. (IAPAR. Circular, 53).

ALMEIDA, F.S; RODRIGUES, B. N. Guia de herbicidas: contribuição para o uso adequado em plantio direto e convencional. Londrina: IAPAR, 1985 . 468p.

AMBROSANO, E.J. Dinâmica do nitrogênio dos adubos verdes, crotalária júncea (Crotalaria juncea) e mucuna-preta (Mucuna aterrima), em dois solos cultivados com milho. Piracicaba, 1994. 83p. Tese (Doutorado)

- Escola Superior de Agricultura "Luiz de Queiroz", Universidade de São Paulo.

BARBER, S. A. Soil-plant interactions in the phosphorus nutrition of plants. In: SYMPOSIUM ON THE ROLE OF PHOSPHORUS IN AGRICULTURE, Muscle Shoals, 1976. The role of phosphorus in agriculture: proceedings. Madison: American Society Agronomy, 1980. cap. 21 , p. 521-613. 
BIERDERBECK, V.O.; CAMPBELL, C.A. Influence of simulated fall and spring conditions on the soil system. I. Effect on soil microflora. Soil Science Society America: Proceedings. Madison: Soil Science Society America, 1971. v. 35, n.1, jan/feb, p. 474-9.

BOLAÑOS, J. Suelos en relación a labranza de conservación: aspectos físicos. In: LABRANZA DE CONSERVACIÓN EN MAIZ, El Batan, 1988. El Batan: CIMMYT/PROCIANDINO, 1989. p. 19-42.

BRIGGLE, L.W. Introduction to energy use in wheat production. In. PIMENTEL, D. Handbook of energy utilization in agriculture. Boca Raton: CRC Press, 1980. p. 109-16.

BUCKMANN, H.O.; BRADY, N.C. Natureza e propriedades dos solos. Rio de Janeiro: Freitas Bastos, 1979. 647 p.

BUJAN, A.; QUITEQUI, M.I; QUITEGUI, M.C.; GHELFI, L.E.P. de; DEYBE, D. Ensayo de aprovechamiento de la residualidade de un fertilizante nitrogenado $\left[\left({ }^{15} \mathrm{NH}_{4}\right)_{2} \mathrm{SO}_{4}\right]$ por un cultivo de trigo mediante el empleo de una tecnica isotopica. In: REGIONAL COLLOQUIUM ON SOIL ORGANIC MATTER STUDIES, Piracicaba, 1982. Regional colloquium on soil organic matter studies: proceedings. Piracicaba: Centro Energia Nuclear Aplicado Agricultura, 1982. p. 209-14.

BULISANI, E.A.; BRAGA, N.R. Potencialidades para utilização de leguminosas como cobertura vegetal de inverno no Estado de São Paulo. In: FANCELLI, A.L., coord. Atualização em plantio direto. Campinas: Fundação Cargill, 1985. p. 223-35.

BULISANI, E.A.; BRAGA, N.R.; ROSTON, A.J. Utilização de leguminosas, como cobertura de solo em sistemas de adubação verde ou rotação de culturas. In: ENCONTRO PAULISTA DE PLANTIO DIRETO, 1, Piracicaba, 1987. Piracicaba: FEALQ, 1987. p. 63-70.

CALEGARI, A. Leguminosas para adubação verde de verão no Paraná. Londrina: IAPAR, 1995. 114p. (IAPAR. Circular, 80). 
CAMPOS, B.C. de; REINERT, D.J.; NICOLODI, R.; RUEDELL, J.; PETRERE, C. Estabilidade estrutural de um latossolo vermelho-escuro distrófico após sete anos de rotação de culturas e sistemas de manejo de solo. Revista Brasileira Ciência Solo., v. 19, p. 121-6, 1995.

CARDOSO, E.M. Contribuição para o estudo da adubação verde dos canaviais. Piracicaba, 1956. 109 p. Tese (Doutorado) - Escola Superior de Agricltura "Luiz de Queiroz", Universidade São Paulo.

CARVALHO, S.L.C.; CALEGARI, A. Manejo e cobertura de solos do pomar. In: FUNDAÇÃO INSTITUTO AGRONÔMICO DO PARANÁ. A cultura da macieira no Paraná. Londrina: 1988 . p.50-63. (IAPAR. Circular, 50).

CHICHESTER, F.W. Effects of increased fertilizer rates on nitrogen content of runoff and percolate from monolith lysimeters. Journal Environmental Quality, v. 6, p. 211-7, 1977.

CHRISTIANSON, C.B.; CARMONA, G.; KLEIN, M.O.; HOWARD, R.G. Impact on amonia volatilization losses of mixing $\mathrm{KCl}$ of high $\mathrm{pH}$ with urea. Fertilizer Research, v. 40, p. 89-92, 1995.

COSTA, J.D.; AMARAL, E. Produção de sementes de Crotalaria juncea L. na presença e na ausência de insetos polinizadores. Revista de Agricultura, v. LI, $n^{\circ} 1$, p. 57-60. 1976.

COSTA, J.D.; LOVADINI, L.A.C.; KIHL, R.A.S. Autocompatibilidade em Crotalaria juncea L. Revista de Agricultura, v. XLVIII, $n^{\circ} 4$, p. 148. 1973.

DABIN, B. Méthode d'extraction et de fractionnement des matiéres humiques du sol. Application à quelques études pédologiques et agronomiques dans les sols tropicaux. Cahiers ORSTOM, Sér. pédol., v. XIV, n. 4, p. 287-97, 1976.

DERSPCH, R.; ROTH, C.H.; SIDIRAS, N.; KOPKE, U. Controle de erosão no Paraná, Brasil: sistemas de cobertura do solo, plantio direto e preparo conservacionista do solo. Londrina: GTZ/IAPAR, 1991. 272 p. 
EMPRESA BRASILEIRA DE PESQUISA AGROPECUÁRIA. Serviço de levantamento de reconhecimento dos solos do Estado do Paraná. Curitiba: EMBRAPA-SNLCS/SUDESUL/IAPAR, 1984. v. 2, (EMBRAPA-SNLCS. Boletim Técnico, 57).

FANCELLI, A.L.; FAVARIN, J. L. O sistema de plantio direto. In: ENCONTRO PAULISTA DE PLANTIO DIRETO, 1., Piracicaba, 1987. Plantio direto. Piracicaba: FEALQ, 1987. p.11-7.

FASSBENDER, H.W. \& BORNEMISZA, E. Química de suelos: con énfasis en suelos de América Latina. 2. Ed. San José: IICA, 1994. 420 p.

FELIPE JÚNIOR, G. de; SOCOLOWSKI, J.C.; FANTI, O.D.J. Considerações sobre as tecnologias e a evolução da indústria de fertilizantes nitrogenados. In: SIMPÓSIO SOBRE FERTILIZANTES NA AGRICULTURA BRASILEIRA, 1. Brasília, 1984. Anais. Brasília: EMBRAPA-DEP, 1984. p. 21-71.

FRANCO, A. A.; SOUTO, S.M. Contribuição da fixação biológica de $\mathrm{N}_{2}$ na adubação verde. In: ENCONTRO NACIONAL SOBRE ADUBAÇÃO VERDE, 1., Rio de Janeiro, 1983. Adubação verde no Brasil. Campinas: Fundação Cargill, 1984. p. 199-215.

FRANZLUEBBERS, A.J.; HONS, F.M.; SALADINO, V.A. Sorghum, wheat and soybean production as affected by long-term tillage, crop sequence and N fertilization. Plant and Soil. v. 173, p. 55-65, 1995.

FREE, J.B. Insect pollination of crops. 2.ed. New York: Academic Press, 1994. 544 p.

FREITAS, P.L. de; CASTRO, A.F. de. Estimativas das perdas de solo e nutrientes por erosão no Estado do Paraná. In: ENCONTRO BRASILEIRO DE CONSERVAÇÃO DO SOLO, 3., Brasília, 1980.

FRYREAR, D.W.; BILBRO, J.D. Wind erosion control with residues and related practices. In: UNGER, P.W. Managing agricultural residues. Boca Raton: Lewis Publ., 1994. p. 7-18. 
GALLO, P.B.; LAVORENTI, A.; SAWAZAKI, E.; HIROCE, R.; MASCARENHAS, H.A.A. Efeitos de cultivos anteriores de soja na produção e no teor de nitrogênio das folhas e dos grãos de milho. Revista Brasileira Ciência Solo, v. 5, p. 64-7, 1981.

GENTIL, L. V. Aspectos econômicos do plantio direto. In: Seminário Internacional do Sistema Plantio Direto, 1, Passo Fundo 1995. Resumos. Passo Fundo: EMBRAPA-CNPT, 1995. p. 9-12.

GRIFFITH, D.R.; MANNERING, J.V.; BOX, J.E. Soil and moisture management with reduced tillage. In: SPRAGUE, A.M.; TRIPLETT, G.B. No-tillage and surface-tillage agriculture: the tillage revolution. New York: John Wiley, 1986. p. 19-55.

GUILLARD, K.; GRIFFIN, G.F.; ALLINSON, D.W.; RAFEY, M.M.; YAMARTINO, W.R.; PIETRZYK, S.W. Nitrogen utilization of selected cropping system in the U.S. Northeast: I. Dry matter Yield, N uptake, apparent $\mathrm{N}$ recovery, and $\mathrm{N}$ use efficiency. Agronomy Journal, v. 87, p. 193-9, 1995.

GUILLARD, K.; GRIFFIN, G.F.; ALLINSON, D.W.; YAMARTINO, W.R.; RAFEY, M.M.; PIETRZYK, S.W. Nitrogen utilization of selected cropping system in the U.S. Northeast: II. Dry matter Yield, N uptake, apparent $\mathrm{N}$ recovery, and $\mathrm{N}$ use efficiency. Agronomy Journal, v. 87, p. 199-207, 1995.

HALL, G.F.; LOGAN, J.J.; YOUNG, K.K. Processes of soil erosion by water. In: FOLLET, R.F; STEWART, B.A., ed. Soil erosion and crop productivity. Madison: American Society Agronomy, 1985. p.137-62.

HARGROVE, W.L. Soil, environmental, and managment factors influencing ammonia volatilization under field conditions. In: BOCK, B.R.; KISSEL, D.E. Ammonia volatilization from urea fertilizers. Muscle Shoals: National Fertilizer Development Center, 1988. p. 1736. (Bulletin Y-206).

HARGROVE, W.L. Winter legumes as a nitrogen source for no-till grain sorghum. Agronomy Journal, v. 78, p. 70, 1986. 
HARRIS, R.F.; CHESTERS, G.; ALLEN, O.N. Dynamics of soil aggregation. Advance Agronomy, v. 18, p. 107-69, 1966.

HEADY, E.O. Economic impacts of energy prices on agriculture. In: STANHILL, G. Energy and agriculture. Berlin: Springer-Verlag, 1984. p. 10-22.

HEICHEL, G.H. Assessing the fossil energs costs of propagating agricultural crops. In: PIMENTEL, D., ed. Handbook of energy utilization in agriculture. Boca Raton: CRC Press, 1980. p. 27-33.

IGARASHI, S. Ocorrência e controle de doenças - doenças foliares. In: FUNDAÇÃO INSTITUTO AGRONÔMICO DO PARANÁ. Plantio direto no Estado do Paraná. Londrina: IAPAR, 1981. p. 171-5. (IAPAR. Circular Técnica, 23).

INSTITUTO AGRONÔMICO DO PARANÁ. Cartas climáticas do Estado do Paraná. Londrina: IAPAR, 1994. 45p.

INSTITUTO AGRONÔMICO DO PARANÁ. Recomendações técnicas para a cultura do trigo no Estado do Paraná. Londrina: IAPAR, 1986. 101 p. (IAPAR. Circular, 46).

INSTITUTO AGRONÔMICO DO PARANÁ. Recomendações técnicas para a cultura do trigo no Estado do Paraná. Londrina: IAPAR, 1996. 116 p. (IAPAR. Circular, 89).

INSTITUTO AGRONÔMICO DO PARANÁ. Relatório técnico anual, 1979. Londrina: IAPAR, 1980. p. 123-45.

INSTITUTO AGRONÔMICO DO PARANÁ. Relatório técnico anual, 1978. Londrina: IAPAR, 1979. p. 205-18.

INSTITUTO AGRONÔMICO DO PARANÁ. Relatório técnico anual, 1977. Londrina: IAPAR, 1978. p. 221-31.

JABRO, J.D.; TOTH, J.D.; DOU, Z.; FOX, R.H.; FRITTON, D. D. Evaluation of nitrogen version of leachm for predicting nitrate leaching. Soil Science, v. 160, n.3, p. 209-17, Sept, 1995. 
JENKINSON, D.S.; AYNABA, A. Decomposicion of carbon-14 labelled plant material under tropical conditions. Soil Science Society American Journal, v. 41, p. 912-5, 1977.

KELLEY, K.W. Rate and time of nitrogen application for wheat following different crops. Journal Production Agriculture, v. 8, p. 339-45, 1995.

KEMPER, B.; VIEIRA, M.J. Características físicas de cinco solos do Paraná, sua relação com a erodibilidade e possibilidades para o melhoramento das condições físicas do solo. In: CONGRESSO BRASILEIRO DE CIÊNCIA DO SOLO, 17., Manaus, 1979. Resumos. Manaus: SBCS, 1979. p. 94.

KEMPER, D. Factors and logic which lead to no-till production systems in the U.S. In: SEMINÁRIO INTERNACIONAL DO SISTEMA PLANTIO DIRETO, 1., Passo Fundo, 1995. Resumos. Passo Fundo: EMBRAPA-CNPT, 1995. p. 49-53.

KRIEG, D.R. Stress tolerance mechanisms in above ground organs. In: ADAPTATION OF PLANTS TO SOIL STRESSES, Lincoln , 1993. Adaptation of plants to soil stresses: proceedings. Lincoln: Intsormil, n. $94-2,1994$. p. 65-80.

KUIPERS, $\mathrm{H}$. Process in physical soil degradation in mechanised agriculture. In: LAND USE SEMINAR ON SOIL DEGRADATION, Wageningen, 1980. Soil degradation: proceedings. Rotterdam: A.A. Balkena, 1982. p. 7-18.

LAL, R. Conservation tillage for sustainable agriculture: tropics versus temperate environments. Advance Agronomy, v. 42, p. 86-185, 1989.

LOMBARDI NETO, F., BERTONI, J. Tolerância de perdas de terra para solos do Estado de São Paulo. Campinas: Institutuo Agronômico, 197512 p. (IAC. Boletim Técnico, 28).

MALAVOLTA, E. Manual de química agrícola: nutrição mineral de plantas e fertilidade do solo. São Paulo: Ceres, 1976. 528 p. 
MASCARENHAS, H.A.A.; HIROCE, R.; BRAGA, N.R.; MIRANDA, M.A.C. de; BULISANI, E.A.; POMMER, C.V.; SAWAZAKI, E.; GALLO, E.; PEREIRA, J.C.V.N.A. Efeito do nitrogênio residual de soja na produção de milho. 2. ed. Campinas: Instituto Agronômico, 1986. 24 p. (IAC. Boletim Técnico, 58).

MASCARENHAS, H.A.A.; TANAKA, R.T.; COSTA, A.A.; ROSA, F.V. \& COSTA, V.F. Efeito residual das leguminosas sobre o rendimento físico e econômico da cana-planta. Campinas: Instituto Agronômico, 1994. 15 p. (IAC. Boletim Científico, 32).

MCLINNES, K.J.; FERGUSON, R.B.; KISSEL D.E.; KANEMASU, E.T. Ammonia loss from applications of urea-ammonium nitrate solution to straw residue. Soil Science Society American Journal, v. 50, p. 96974, 1982.

MEDINA, J.C. Plantas fibrosas da flora mundial. Campinas: IAC/CNPq, 1959. $913 \mathrm{p}$.

MEHTA, Y.R. Ocorrência e controle de doenças - doenças de raízes. In: FUNDAÇÃO INSTITUTO AGRONÔMICO DO PARANÁ. Plantio direto no Estado do Paraná. Londrina: IAPAR, 1981. p. 175-8. (IAPAR. Circular, 23).

MELLO, R. de. Análise energética de agroecossistemas: o caso de Santa Catarina. Florianópolis, 1986. 139p. Dissertação (Mestrado) Universidade Federal de Santa Catarina.

MENGEL, K.; KIRBY, E.A. Principles of plant nutrition. 4. ed. Bern: International Potash Institute, $1987.687 \mathrm{p}$.

MIYASAKA, S.; CAMARGO, O.A. de; CAVALERI, A.P.; GODOY, I.J. de; WERNER, J.C.; CURI, S.M.; LOMBARDI NETO, F.; MEDINA, J.C.; CERVELIN, MG.S. da; BULISANI, E.A. Adubação orgânica, adubação verde e rotação de culturas no Estado de São Paulo. Campinas: Fundação Cargill, 1983. 140 p. 
MONDARDO, A. \& BISCAIA, R.M. Controle de erosão. In: INSTITUTO AGRONÔMICO DO PARANÁ, Londrina,1981. Plantio direto no Estado do Paraná. Londrina: IAPAR, 1981. p. 33-9. (IAPAR. Circular, 23).

MONTOYA, L.J. Aspectos de economicidade do manejo do solo em plantio direto. Londrina: IAPAR, 1984. 20 p. (IAPAR. Informe da Pesquisa, 57).

MUZILLI, O. A adubação verde como alternativa para a melhoria da fertilidade do solo e racionalização do uso de fertilizantes. Londrina: IAPAR, 1986. 14p. (IAPAR. Informe de Pesquisa, 68).

MUZILLI, O. Manejo do solo como alternativa para minimizar fatores ambientais adversos a cultura do trigo em áreas semi-tropicais brasileiras. Londrina: IAPAR, 1985. 17p. (IAPAR. Circular, 42).

MUZILLI, O. Princípios e perspectivas de expansão. In: FUNDAÇÃO INSTITUTO AGRONÔMICO DO PARANÁ. Plantio direto no Estado do Paraná. Londrina: IAPAR, 1981. p.11-7. (IAPAR. Circular, 23).

MUZILLI, O.; OLIVEIRA, E.L.; CALEGARI, A. Manejo do solo manejo da fertilidade do solo. In: INSTITUTO AGRONÔMICO DO PARANÁ. A cultura do milho no Paraná. Londrina: IAPAR, 1991. p. 97-123. (IAPAR. Circular, 68).

MUZILLI, O.; OLIVEIRA, E.L.; GERAGE, A.C.; TORNERO, M.T. Adubação nitrogenada em milho no Paraná: influência da recuperação do solo com adubação verde de inverno nas respostas a adubação nitrogenada. Pesquisa Agropecuária Brasileira, v. 18, n. 1, p. 23-7, 1983.

NEVES, E.V.; SHIROTA, R. Considerações sobre a importância, determinação e atualização dos custos agrícolas. Revista da ADEALQ, v 4, p . 62-9, 1986. 
NOGUEIRA, R.H.C.; COSTA, J.A.; SILVEIRA, R.C.M.; COUTO, L.A. Polinização de Crotalaria juncea por abelhas nativas. Ecossistema, v. 17, p. 12-6, 1992.

OLIVEIRA, E. de; PARIZOTTO, M.L.V. Características e uso fertilizante do esterco de suíno. Londrina: IAPAR, 1994. 24 p. (IAPAR. Circular, 83).

OLIVEIRA, E.L. Coberturas verdes de inverno e adubação nitrogenada em algodoeiro (Gossypium hirsutum L.). In: REUNIÃO BRASILEIRA DE FERTILIDADE DO SOLO E NUTRIÇÃO DE PLANTAS, 20., Piracicaba, 1992. Anais. Piracicaba: Soc. Bras. Ci. Solo, 1992. p. 284-5.

OWENS, L.B.; EDWARDS, W.M.; SHIPITALO, M.J. Nitrate leaching through lysimeters in a corn-soybean rotation. Soil Science Society American Journal, v. 59, p. 902- 7, 1995.

PHILLIPS, R.E. Efectos del clima sobre la agricultura sin laboreo. In: PHILLIPS, R.E.; PHILLIPS, S.H. Agricultura sin laboreo: principios y aplicaciones. Barcelona: Ed. Bellaterra, 1986. p.12-43.

PHILLIPS, R.E.; PHILLIPS, S.H. Agricultura sin laboreo: principios y aplicaciones. Barcelona: Ediciones Bellaterra, , 1986. 316p.

PHILLIPS, S.H.; YOUNG JR., H.M. No-tillage farming. Milwankee: Reiman Associates, 1973. 224p..

PIETERS, A.J. Green manuring: principles and practice. New York: John Wiley, 1927. 356p.

PIMENTEL, D.; BURGESS, M. Energy inputs in corn production. In: PIMENTEL, D. Handbook og energy utilization in agriculture. Boca Raton: CRC Press, 1980. p. 67-84.

PIMENTEL, D. Handbook of energy utilization in agriculture. Boca Raton: CRC Press, 1980. 475 p.

PRIMAVESI, A. O manejo ecológico do solo. 4. Ed. São Paulo: Nobel, 1980. $541 \mathrm{p}$. 
RAMALHO FILHO, A.; PEREIRA, E.G.; BEEK, K.J. Sistema de avaliação da aptidão agrícola das terras. Brasília: EMBRAPA/SUPLAN, 1978. 70p.

REIS, M.R. Interações entre doenças de cereais de inverno e de milho com o sistema de plantio direto. In: SEMINÁRIO INTERNACIONAL DO SISTEMA PLANTIO DIRETO, 1., Passo Fundo, 1995. Resumos. Passo Fundo: EMBRAPA/CNPT, 1995. p. 3-5.

RODRIGUES, M.B.; KIHEL, J.C. Volatilização de amônia após emprego de uréia em diferentes doses e modos de aplicação. Revista Brasileira Ciência Solo, v.10, n. 1, p. 37-43, 1986.

SALGADO, A.L.B.; AZZIN, A.; PIMENTEL, J.M.; POTASCHEFF JR., J. Instruções para a cultura da Crotalaria juncea. 2. Ed. Campinas: Instituto Agronômico, 1980. 26 p. (IAC. Boletim Técnico, 198).

SANTOS, H.P. dos. Efeito da rotação de culturas no rendimento, na eficiência energética e econômica do trigo, em plantio direto. Piracicaba, 1992. 136 p. Tese (Doutorado) - Escola Superior de Agricultura “Luiz de Queiroz", Universidade São Paulo.

SANTOS, M.A.; RUANO, O. Reação de plantas usadas como adubos verdes à Meloidogyne incognita à raça 3 e M. javanica. Nematologia Brasileira, v. 11, p. 184-97, 1987.

SCHOMBERG, H.H.; FORD, P.B.; HARGROVE, W.L. Influence of crop residues on nutrient cycling and soil chemical. In: UNGER, P.W. Managing agricultural residues. Boca Raton: Lewis Publ., 1994. p. 7-18.

SCOTT, W.O.; KRUMMEL, J. Energy used in producing soybeans. In: Pimentel, D. Handbook of energy utilization in agriculture. Boca Raton: CRC Press, 1980. p. 117-121.

SHIPLEY, P.R.; MEISINGER, J.J.; DECKER, A.M. Conserving residual corn fertilizer nitrogen with winter cover. Agronomy Journal, v. 84, p. 869-76, 1992. 
SILVA, A. J.; LIMA JÚNIOR, M.A.; FERREIRA, N.C.M.; FRAGA, V. S. Perdas de amônia por volatilização provenientes da uréia aplicada a solos dos trópicos úmidos. Revista Brasileira Ciência Solo, v. 19, p. 141-4, 1995.

SILVA, J.F.V.; CARNEIRO, R.G. Reação de adubos verdes de verão e de inverno às raças 1, 2 e 4 de Meloidogyne incognita. Nematologia Brasileira, v. 16, p. 12-8, 1992.

SIMS, J.T.; VASILAS, B.L.; GARTLEY, K.L., MILLIKEN, B.; GREEN, V. Evaluation of soil and plant nitrogen tests for maize on manured soils of the Atlantic Coastal Plain. Agronomy Journal, v. 87, p. 213-22, 1995.

SINGH, G.R.; SINGH, T.A. Nitrogen movement and uptake by rice fertilized with urea supergranules in two contrasting Mollisols. Fertilizer Research, v. 16, n. 1, p. 37-46, 1988.

SMITH, O.L. Soil microbiology: a model of decomposition and nutrient cycling. Boca Raton: CRC Press, 1982. 273p.

SPRAGUE, M.A.; TRIPLETT, G.B. No-tillage and surface-tillage agriculture: the tillage revolution. New York: John Wiley, 1986. $467 p$.

TISDALE, S.L.; NELSON, W.L.; BEATON, J.D. Soil fertility and fertilizers. 4. ed. New York: Macmillan, 1985. 754 p.

VEIGA, A.A.; BULISANI, E.A.; MIYASAKA, S.; ALMEIDA, L. D'A.; RAIJ, B. van. Efeitos da incorporação ao solo de massa vegetal de Crotalaria juncea, da calagem e da adubação com nitrogênio e fósforo sobre a produção do feijoeiro. 2. Ed. Campinas: Instituto Agronômico, 1982. p. 1-19. (IAC. Boletim Técnico, 48).

VIEIRA, M.J. Propriedades físicas do solo. In: INSTITUTO AGRONÔMICO DO PARANÁ. Plantio direto no Estado do Paraná. Londrina: IAPAR, 1981. p. 19-30. (IAPAR. Circular, 23). 
VIEIRA, M.J. Embasamento técnico do sub-programa de manejo e conservação do solo - Paraná-Rural. In: PARANÁ. Secretaria da Agricultura e do Abastecimento. Manual técnico do sub-programa de manejo e conservação do solo. 2. ed. Curitiba: SEAB, 1994. cap. 2, p. $12-40$.

WILES, J.C.; YAMAOKA, R.S. Mecanização. In: INSTITUTO AGRONÔMICO DO PARANÁ. Plantio direto no Estado do Paraná. Londrina: IAPAR, 1981. p. 59-94. (IAPAR. Circular, 23).

WUTKE, A.C.P.; ALVAREZ, R. Restauração do solo para a cultura de cana-de-açúcar, III: período 1958-61 e considerações gerais. Bragantia, v. 27, p.201-17, 1968.

YODER, R.E. A direct method of aggregate analysis of soils and a study of the physical nature of erosion losses. Journal American Society Agronomy, v. 29, n. 5, p. 337-51, 1936. 
APÊNDICE 
Tabela 1. Custo de produção atualizado a moeda Real (R $\$$ ) por hectare de trigo, safra 1991.

\begin{tabular}{|c|c|c|c|c|c|c|c|c|}
\hline \multirow[t]{2}{*}{ Especificação } & \multirow[t]{2}{*}{ Quant. } & \multirow{2}{*}{$\begin{array}{c}\text { Un } \\
\text {. }\end{array}$} & \multicolumn{6}{|c|}{ Tratamentos } \\
\hline & & & $\mathrm{T} 1$ & T2 & T3 & T4 & T5 & T6 \\
\hline Herb. manejo (Glifosato) & 1,5 & 1 & & & 17,57 & & 17,57 & 17,57 \\
\hline Crotalária(semead./rolagem) & 20 & $\mathrm{~kg}$ & 77,10 & 77,10 & & 77,10 & & \\
\hline Semente & 180 & $\mathrm{~kg}$ & 58,82 & 58,82 & 58,82 & 58,82 & 58,82 & 58,82 \\
\hline Fertilizante (4-30-10) & 200 & $\mathrm{~kg}$ & 54,00 & 54,00 & 54,00 & 54,00 & 54,00 & 54,00 \\
\hline Herbicida $(2,4-D)$ & 1,5 & 1 & & & 14,05 & & 14,05 & 14,05 \\
\hline Fungicida (Propiconazole) & 0,5 & 1 & 27,32 & 27,32 & 27,32 & 27,32 & 27,32 & 27,32 \\
\hline Sulfato de amônio & 150 & $\mathrm{~kg}$ & 28,82 & 52,82 & 28,82 & & 52,82 & 28,82 \\
\hline Colheita & 1 & ha & & & erda tota & por gead & & \\
\hline \multicolumn{3}{|c|}{ Total de Custos Variáveis } & 246,06 & 270,06 & 200,58 & 217,24 & 224,58 & 200,58 \\
\hline \multicolumn{3}{|c|}{ Equivalente ressarc. seguro agrícola } & 200,58 & 200,58 & 200,58 & 200,58 & 200,58 & 200,58 \\
\hline \multicolumn{3}{|c|}{ Renda } & $(-45,48)$ & $(-69,48)$ & - & $(-16,66)$ & $(-24,00)$ & - \\
\hline
\end{tabular}

Tabela 2. Custo de produção atualizado a moeda Real $(\mathrm{R} \$)$ por hectare de trigo, safra 1992.

\begin{tabular}{l|c|c|c|c|c|cc|c}
\hline \hline \multicolumn{1}{c|}{ Especificação } & Quant. & \multirow{2}{*}{ Un. } & \multicolumn{6}{|c}{ Tratamentos } \\
\cline { 5 - 9 } & & & $\mathrm{T} 1$ & $\mathrm{~T} 2$ & $\mathrm{~T} 3$ & $\mathrm{~T} 4$ & $\mathrm{~T} 5$ & T6 \\
\hline \hline Herb. manejo (Glifosato) & 1,5 & $\mathrm{l}$ & 17,57 & 17,57 & 17,57 & 17,57 & 17,57 & 17,57 \\
\hline Semente & 180 & $\mathrm{~kg}$ & 58,82 & 58,82 & 58,82 & 58,82 & 58,82 & 58,82 \\
\hline Fertilizante (4-30-10) & 200 & $\mathrm{~kg}$ & 54,00 & 54,00 & 54,00 & 54,00 & 54,00 & 54,00 \\
\hline Herbicida (2,4-D) & 1,5 & 1 & 14,05 & 14,05 & 14,05 & 14,05 & 14,05 & 14,05 \\
\hline Inseticida (Pirimicarb) & 0,15 & $\mathrm{~kg}$ & 8,22 & 8,22 & 8,22 & 8,22 & 8,22 & 8,22 \\
\hline Fungicida (Propiconazole) & 0,5 & 1 & 27,32 & 27,32 & 27,32 & 27,32 & 27,32 & 27,32 \\
\hline Sulfato de amônio & 150 & $\mathrm{~kg}$ & 28,82 & 52,82 & 28,82 & & 52,82 & 28,82 \\
\hline Colheita & 1 & $\mathrm{ha}$ & 29,65 & 29,65 & 29,65 & 29,65 & 29,65 & 29,65 \\
\hline Total de Custos Operacionais & & 238,45 & 262,45 & 238,45 & 208,63 & 262,45 & 238,45 \\
\hline Receita Bruta (R\$ 7,74.sc & & & 419,44 & 447,31 & 404,21 & 387,18 & 423,95 & 408,73 \\
\hline Renda & & 180,99 & 184,86 & 165,76 & 178,55 & 161,50 & 170,28 \\
\hline
\end{tabular}


Tabela 3. Custo de produção atualizado a moeda Real ( $\mathrm{R} \$$ ) por hectare de trigo, safra 1993.

\begin{tabular}{l|c|c|c|c|c|cc|c}
\hline \hline \multicolumn{1}{c|}{ Especificação } & \multirow{2}{*}{ Quant } & \multirow{2}{*}{ Un } & \multicolumn{7}{|c}{ Tratamentos } \\
\cline { 7 - 11 } & & & T1 & T2 & T3 & T4 & T5 & T6 \\
\hline \hline Herb.manejo (Glifosato) & 1,5 & $\mathrm{l}$ & & & 17,57 & & 17,57 & 17,57 \\
\hline Crotalária(semead./rolagem) & 20 & $\mathrm{~kg}$ & 77,10 & 77,10 & & 77,10 & & \\
\hline Semente & 180 & $\mathrm{~kg}$ & 58,82 & 58,82 & 58,82 & 58,82 & 58,82 & 58,82 \\
\hline Fertilizante (4-30-10) & 200 & $\mathrm{~kg}$ & 54,00 & 54,00 & 54,00 & 54,00 & 54,00 & 54,00 \\
\hline Herbicida (2,4-D) & 1,5 & 1 & & & 14,05 & & 14,05 & 14,05 \\
\hline Fungicida (Tebuconazole) & 0,75 & $\mathrm{l}$ & 30,02 & 30,02 & 30,02 & 30,02 & 30,02 & 30,02 \\
\hline Sulfato de amônio & 150 & $\mathrm{~kg}$ & 28,82 & 52,82 & 28,82 & & 52,82 & 28,82 \\
\hline Colheita & 1 & ha & 29,65 & 29,65 & 29,65 & 29,65 & 29,65 & 29,65 \\
\hline Total de Custos Operacionais & & & 278,41 & 302,41 & 232,93 & 267,59 & 232,93 & 232,93 \\
\hline Receita Bruta (R $\$ 7,74$. sc $^{-1}$ ) & & & 336,71 & 347,68 & 288,06 & 243,66 & 325,23 & 334,91 \\
\hline Renda & & 58,30 & 45,00 & 55,71 & $-23,93$ & 92,30 & 101,98 \\
\hline
\end{tabular}

Tabela 4. Custo de produção atualizado a moeda Real ( $\mathrm{R} \$$ ) por hectare de trigo, safra 1994.

\begin{tabular}{|c|c|c|c|c|c|c|c|c|}
\hline \multirow{2}{*}{ Especificação } & \multirow[t]{2}{*}{ Quant. } & \multirow[t]{2}{*}{ Un } & \multicolumn{6}{|c|}{ Tratamentos } \\
\hline & & & T1 & $\mathrm{T} 2$ & T3 & $\mathrm{T} 4$ & T5 & T6 \\
\hline Herb. manejo (Glifosato) & 1,5 & 1 & 17,57 & 17,57 & 17,57 & 17,57 & 17,57 & 17,57 \\
\hline Semente & 180 & $\mathrm{~kg}$ & 58,82 & 58,82 & 58,82 & 58,82 & 58,82 & 58,82 \\
\hline Fertilizante $(4-30-10)$ & 200 & $\mathrm{~kg}$ & 54,00 & 54,00 & 54,00 & 54,00 & 54,00 & 54,00 \\
\hline Herbicida $(2,4-\mathrm{D})$ & 1,5 & 1 & 14,05 & 14,05 & 14,05 & 14,05 & 14,05 & 14,05 \\
\hline Inseticida (Pirimicarb) & 0,15 & $\mathrm{~kg}$ & 8,22 & 8,22 & 8,22 & 8,22 & 8,22 & 8,22 \\
\hline Fungicida (Tebuconazole) & 0,75 & 1 & 30,02 & 30,02 & 30,02 & 30,02 & 30,02 & 30,02 \\
\hline Sulfato de amônio & 150 & $\mathrm{~kg}$ & 28,82 & 52,82 & 28,82 & & 52,82 & 28,82 \\
\hline Colheita & 1 & ha & \multicolumn{6}{|c|}{ Perda total por geada } \\
\hline \multicolumn{3}{|c|}{ Total de Custos Operacionais } & 211,50 & 235,50 & 211,50 & 182,68 & 235,50 & 211,50 \\
\hline \multicolumn{3}{|c|}{ Equiv. Ressarc. seguro agrícola } & 211,50 & 211,50 & 211,50 & 211,50 & 211,50 & 211,50 \\
\hline \multicolumn{3}{|c|}{ Renda } & - & $(-24,00)$ & - & 28,82 & $(-24,00)$ & - \\
\hline
\end{tabular}


Tabela 5. Custo de produção atualizado a moeda Real ( $\mathrm{R} \$$ ) por hectare de trigo, safra 1995.

\begin{tabular}{|c|c|c|c|c|c|c|c|c|}
\hline \multirow[t]{2}{*}{ Especificação } & \multirow[t]{2}{*}{ Quant } & \multirow[t]{2}{*}{ Un } & \multicolumn{6}{|c|}{ Tratamentos } \\
\hline & & & T1 & T2 & T3 & T4 & T5 & T6 \\
\hline Herb. manejo (Glifosato) & 1,5 & 1 & & & 17,57 & & 17,57 & 17,57 \\
\hline Crotalária(semead./rolagem) & 20 & $\mathrm{~kg}$ & 77,10 & 77,10 & & 77,10 & & \\
\hline Semente & 180 & $\mathrm{~kg}$ & 58,82 & 58,82 & 58,82 & 58,82 & 58,82 & 58,82 \\
\hline Fertilizante $(4-30-10)$ & 200 & $\mathrm{~kg}$ & 54,00 & 54,00 & 54,00 & 54,00 & 54,00 & 54,00 \\
\hline Herbicida $(2,4-D)$ & 1,5 & 1 & & & 14,05 & & 14,05 & 14,05 \\
\hline Sulfato de amônio & 150 & $\mathrm{~kg}$ & 28,82 & 52,82 & 28,82 & & 52,82 & 28,82 \\
\hline Colheita & 1 & ha & 29,65 & 29,65 & 29,65 & 29,65 & 29,65 & 29,65 \\
\hline \multicolumn{3}{|l|}{ Total de Custos Operacionais } & 248,39 & 272,39 & 202,91 & 219,57 & 226,91 & 202,91 \\
\hline \multicolumn{3}{|l|}{ Receita Bruta $\left(\mathrm{R} \$ 7,74 . \mathrm{sc}^{-1}\right)$} & 178,00 & 170,17 & 153,23 & 183,52 & 152,85 & 137,70 \\
\hline \multicolumn{3}{|l|}{ Renda } & $-70,39$ & $-102,22$ & 49,68 & $-36,05$ & -74.06 & $-65,21$ \\
\hline
\end{tabular}

Tabela 6. Custo de produção atualizado para moeda Real $(\mathrm{R} \$)$ por hectare de soja, safra 1992.

\begin{tabular}{|c|c|c|c|c|c|c|c|c|}
\hline \multirow[t]{2}{*}{ Especificação } & \multirow[t]{2}{*}{ Quant. } & \multirow[t]{2}{*}{ Un. } & \multicolumn{6}{|c|}{ Tratamentos } \\
\hline & & & $\mathrm{T} 1$ & T2 & T3 & T4 & T5 & T6 \\
\hline Escarificação do solo & 1 & ha & 20,68 & 20,68 & 20,68 & 20,68 & 20,68 & 20,68 \\
\hline Grade niveladora & 1 & ha & 10,06 & 10,06 & 10,06 & 10,06 & 10,06 & 10,06 \\
\hline Semente & 90 & $\mathrm{~kg}$ & 38,68 & 38,68 & 38,68 & 38,68 & 38,68 & 38,68 \\
\hline Fertilizante $(0-20-20)$ & 200 & $\mathrm{~kg}$ & 51,60 & 51,60 & 51,60 & 51,60 & 51,60 & 51,60 \\
\hline $\begin{array}{l}\text { Herbicida: Trifularina }+ \\
\text { Imazaquin }\end{array}$ & $\begin{array}{l}2 \\
1\end{array}$ & $\begin{array}{l}1 \\
1\end{array}$ & & & 38,01 & & 38,01 & 38,01 \\
\hline Inseticida (Endossulfã) & 1,6 & 1 & 21,94 & 21,94 & 21,94 & 21,94 & 21,94 & 21,94 \\
\hline Capina & 2 & $\mathrm{D} / \mathrm{H}$ & 20,00 & 20,00 & & 20,00 & & \\
\hline Baculovirus & 2 & dose & 6,40 & 6,40 & 6,40 & 6,40 & 6,40 & 6,40 \\
\hline Colheita & 1 & ha & 29,75 & 29,75 & 29,75 & 29,75 & 29,75 & 29,75 \\
\hline \multicolumn{3}{|c|}{ Total de Custos Operacionais } & 199,11 & 199,11 & 217,12 & 199,11 & 217,12 & 217,12 \\
\hline \multicolumn{3}{|c|}{ Receita Bruta $\left(\mathrm{R} \$ 11,50 . \mathrm{sc}^{-1}\right)$} & 495,68 & 499,15 & 467,20 & 491,84 & 429,85 & 443,33 \\
\hline \multicolumn{3}{|l|}{ Renda } & 296,57 & 300,04 & 250,08 & 292,73 & 212,73 & 226,21 \\
\hline
\end{tabular}


Tabela 7. Custo de produção atualizado para moeda Real (R\$) por hectare de soja, safra 1993.

\begin{tabular}{|c|c|c|c|c|c|c|c|c|}
\hline \multirow[t]{2}{*}{ Especificação } & \multirow[t]{2}{*}{ Quant. } & \multirow[t]{2}{*}{ Un. } & \multicolumn{6}{|c|}{ Tratamentos } \\
\hline & & & $\mathrm{T} 1$ & $\mathrm{~T} 2$ & T3 & $\mathrm{T} 4$ & T5 & T6 \\
\hline Herb.manejo (Glifosato) & 1,5 & 1 & & & & & & 17,57 \\
\hline Semente & 90 & $\mathrm{~kg}$ & & & & & & 38,68 \\
\hline Fertilizante $(0-20-20)$ & 200 & $\mathrm{~kg}$ & & & & & & 51,60 \\
\hline Herbicida: Triflularina & 2,5 & 1 & & & & & & \\
\hline Imazaquin & 1,0 & 1 & & & & & & 38,01 \\
\hline Inseticida (Endossulfã) & 1,6 & 1 & & & & & & 21,94 \\
\hline Baculovirus & 2 & dose & & & & & & 6,40 \\
\hline Colheita & 1 & ha & & & & & & 29,75 \\
\hline \multicolumn{3}{|c|}{ Total de Custos Operacionais } & & & & & & 203,95 \\
\hline \multicolumn{3}{|c|}{ Receita Bruta $\left(\mathrm{R} \$ 10,00 . \mathrm{sc}^{-1}\right)$} & & & & & & 508,88 \\
\hline \multicolumn{3}{|l|}{ Renda } & & & & & & 304,93 \\
\hline
\end{tabular}

Tabela 8. Custo de produção atualizado para moeda Real (R\$) por hectare de soja, safra 1994.

\begin{tabular}{|c|c|c|c|c|c|c|c|c|}
\hline \multirow[t]{2}{*}{ Especificação } & \multirow{2}{*}{$\begin{array}{c}\text { Qua } \\
\text { nt }\end{array}$} & \multirow[t]{2}{*}{ Un } & \multicolumn{6}{|c|}{ Tratamentos } \\
\hline & & & $\mathrm{T} 1$ & $\mathrm{~T} 2$ & $\mathrm{~T} 3$ & $\mathrm{~T} 4$ & $\mathrm{~T} 5$ & T6 \\
\hline Herb.manejo (Glifosato) & 1,5 & 1 & 17,57 & 17,57 & 17,57 & 17,57 & 17,57 & 17,57 \\
\hline Semente & 90 & $\mathrm{~kg}$ & 38,68 & 38,68 & 38,68 & 38,68 & 38,68 & 38,68 \\
\hline Fertilizante $(0-20-20)$ & 200 & $\mathrm{~kg}$ & 51,60 & 51,60 & 51,60 & 51,60 & 51,60 & 51,60 \\
\hline Capina & 2 & $\mathrm{D} / \mathrm{H}$ & 20,00 & 20,00 & & 20,00 & & \\
\hline Herbicida (Imazaquin) & 1,0 & 1 & & & 33,65 & & 33,65 & 33,65 \\
\hline Inseticida (Endossul fã) & 1,6 & 1 & 21,94 & 21,94 & 21,94 & 21,94 & 21,94 & 21,94 \\
\hline Baculovirus & 2 & dose & 6,40 & 6,40 & 6,40 & 6,40 & 6,40 & 6,40 \\
\hline Colheita & 1 & ha & 29,75 & 29,75 & 29,75 & 29,75 & 29,75 & 29,75 \\
\hline \multicolumn{3}{|c|}{ Total de Custos Operacionais } & 185,94 & 185,94 & 199,59 & 185,94 & 199,59 & 199,59 \\
\hline \multicolumn{3}{|c|}{ Receita Bruta $\left(\mathrm{R} \$ 11,50 . \mathrm{sc}^{-1}\right)$} & 632,55 & 693,39 & 603,10 & 635,44 & 625,24 & 595,21 \\
\hline \multicolumn{3}{|c|}{ Renda } & 446,61 & 507,45 & 403,51 & 449,50 & 425,65 & 395,62 \\
\hline
\end{tabular}


Tabela 9. Custo de produção atualizado para moeda Real $(\mathrm{R} \$)$ por hectare de soja, safra 1995.

\begin{tabular}{|c|c|c|c|c|c|c|c|c|}
\hline \multirow[t]{2}{*}{ Especificação } & \multirow[t]{2}{*}{ Quant. } & \multirow[t]{2}{*}{ Un. } & \multicolumn{6}{|c|}{ Tratamentos } \\
\hline & & & $\mathrm{T} 1$ & $\mathrm{~T} 2$ & T3 & T4 & T5 & T6 \\
\hline Herb.manejo (Glifosato) & 1,5 & 1 & & & & & & 17,57 \\
\hline Semente & 90 & $\mathrm{~kg}$ & & & & & & 38,68 \\
\hline Fertilizante $(0-20-20)$ & 200 & $\mathrm{~kg}$ & & & & & & 51,60 \\
\hline Herbicida (Imazaquin) & 1,0 & 1 & & & & & & 33,65 \\
\hline Inseticida (Endossulfã) & 1,6 & 1 & & & & & & 21,94 \\
\hline Baculovirus & 2 & dose & & & & & & 6,40 \\
\hline Colheita & 1 & ha & & & & & & 29,75 \\
\hline \multicolumn{3}{|c|}{ Total dos Custos Operacionais } & & & & & & 199,59 \\
\hline \multicolumn{3}{|l|}{ Receita Bruta $\left(\mathrm{R} \$ 11,50 . \mathrm{sc}^{-1}\right)$} & & & & & & 554,40 \\
\hline \multicolumn{3}{|l|}{ Renda } & & & & & & 354,81 \\
\hline
\end{tabular}

Tabela 10. Custo de produção atualizado para moeda Real $(\mathrm{R} \$)$ por hectare de soja, safra 1996.

\begin{tabular}{|c|c|c|c|c|c|c|c|c|}
\hline \multirow[t]{2}{*}{ Especificação } & \multirow[t]{2}{*}{ Quant. } & \multirow[t]{2}{*}{ Un. } & \multicolumn{6}{|c|}{ Tratamentos } \\
\hline & & & $\mathrm{T} 1$ & $\mathrm{~T} 2$ & T3 & $\mathrm{T} 4$ & T5 & T6 \\
\hline Herb.manejo (Glifosato) & 1,5 & 1 & 17,57 & 17,57 & 17,57 & 17,57 & 17,57 & 17,57 \\
\hline Semente & 90 & $\mathrm{~kg}$ & 38,68 & 38,68 & 38,68 & 38,68 & 38,68 & 38,68 \\
\hline Fertilizante $(0-20-20)$ & 200 & $\mathrm{~kg}$ & 51,60 & 51,60 & 51,60 & 51,60 & 51,60 & 51,60 \\
\hline Capina & 2 & $\mathrm{D} / \mathrm{H}$ & 20,00 & 20,00 & 50,00 & 20,00 & 50,00 & 40,00 \\
\hline Inseticida (Endossulfã) & 1,6 & 1 & 21,94 & 21,94 & 21,94 & 21,94 & 21,94 & 21,94 \\
\hline Baculovirus & 2 & dose & 6,40 & 6,40 & 6,40 & 6,40 & 6,40 & 6,40 \\
\hline Colheita & 1 & ha & 29,75 & 29,75 & 29,75 & 29,75 & 29,75 & 29,75 \\
\hline \multicolumn{3}{|c|}{ Total dos Custos Operacionais } & 185,91 & 185,91 & 215,91 & 185,91 & 215,91 & 205,91 \\
\hline \multicolumn{3}{|c|}{ Receita Bruta $\left(\mathrm{R} \$ 11,50 . \mathrm{sc}^{-1}\right)$} & 686,36 & 690,76 & 613,53 & 691,73 & 601,84 & 630,20 \\
\hline \multicolumn{3}{|l|}{ Renda } & 500,45 & 504,85 & 397,62 & 505,82 & 385,93 & 424,29 \\
\hline
\end{tabular}


Tabela 11. Custo de produção atualizado para moeda Real $(\mathrm{R} \$)$ por hectare de milho, safra 1993.

\begin{tabular}{l|c|c|c|c|c|cc|c}
\hline \hline \multicolumn{1}{c|}{ Especificação } & \multirow{2}{*}{ Quant. } & \multirow{2}{*}{ Un. } & \multicolumn{7}{|c}{ Tratamentos } \\
\cline { 4 - 10 } & & & T1 & T2 & T3 & T4 & T5 & T6 \\
\hline \hline Herb.manejo (Glifosato) & 1,5 & 1 & 17,57 & 17,57 & 17,57 & 17,57 & 17,57 & - \\
\hline Semeadura (matraca) & 2 & $\mathrm{D} / \mathrm{H}$ & 20,00 & 20,00 & 20,00 & 20,00 & 20,00 & - \\
\hline Raleação do estande & 6 & $\mathrm{D} / \mathrm{H}$ & 60,00 & 60,00 & 60,00 & 60,00 & 60,00 & - \\
\hline Semente & 20 & $\mathrm{~kg}$ & 64,00 & 64,00 & 64,00 & 64,00 & 64,00 & - \\
\hline Fertilizante (4-30-10) & 200 & $\mathrm{~kg}$ & 51,60 & 51,60 & 51,60 & 51,60 & 51,60 & - \\
\hline Herb.(Atrazine + simazine) & 4 & $\mathrm{l}$ & 21,92 & 21,92 & 21,92 & 21,92 & 21,92 & - \\
\hline Inseticida (Clorpirifós) & 1,6 & 1 & 14,08 & 14,08 & 14,08 & 14,08 & 14,08 & - \\
\hline Sulfato de amônio & 450 & $\mathrm{~kg}$ & 86,46 & 86,46 & 86,46 & 86,46 & 86,46 & - \\
\hline Colheita & 1 & $\mathrm{ha}$ & 39,19 & 39,19 & 39,19 & 39,19 & 39,19 & - \\
\hline Total dos Custos Operacionais & & 388,52 & 388,52 & 388,52 & 388,52 & 388,52 & - \\
\hline Receita Bruta ((R $\$ 7,00$. sc $\left.^{-1}\right)$ & & 937,00 & 980,73 & 942,15 & 935,47 & 956,41 & - \\
\hline Renda & & 548,48 & 592,21 & 553,63 & 546,95 & 567,89 & - \\
\hline
\end{tabular}

Tabela 12. Custo de produção atualizado para moeda Real $(\mathrm{R} \$$ ) por hectare de milho, safra 1995.

\begin{tabular}{l|c|c|c|c|c|cc|c}
\hline \multicolumn{1}{c}{ Especificação } & \multirow{2}{*}{ Quant. } & \multirow{2}{*}{ Un. } & \multicolumn{7}{|c}{ Tratamentos } \\
\cline { 6 - 10 } & & & T1 & T2 & T3 & T4 & T5 & T6 \\
\hline \hline Herb.manejo (Glifosato) & 1,5 & 1 & & & 17,57 & & 17,57 & - \\
\hline Semeadura (matraca) & 2 & D/H & 20,00 & 20,00 & 20,00 & 20,00 & 20,00 & - \\
\hline Raleação do estande & 6 & D/H & 60,00 & 60,00 & 60,00 & 60,00 & 60,00 & - \\
\hline Semente & 20 & $\mathrm{~kg}$ & 64,00 & 64,00 & 64,00 & 64,00 & 64,00 & - \\
\hline Fertilizante (4-30-10) & 200 & $\mathrm{~kg}$ & 51,60 & 51,60 & 51,60 & 51,60 & 51,60 & - \\
\hline Herbicida (Atrazine+simazine) & 7 & 1 & 21,92 & 21,92 & 21,92 & 21,92 & 21,92 & - \\
\hline Inseticida (Clorpirifós) & 1,4 & 1 & 14,08 & 14,08 & 14,08 & 14,08 & 14,08 & - \\
\hline Sulfato de amônio & 450 & 1 & 86,46 & 86,46 & 86,46 & 86,46 & 86,46 & - \\
\hline Colheita & 1 & ha & 39,19 & 39,19 & 39,19 & 39,19 & 39,19 & - \\
\hline Total dos custos Operacionais & & 357,35 & 357,35 & 374,92 & 357,35 & 374,92 & - \\
\hline Receita Bruta (R\$ 7,00.sc ${ }^{-1}$ ) & & & 713,97 & 696,61 & 554,16 & 639,39 & 582,96 & - \\
\hline Renda & & & 356,62 & 339,26 & 179,24 & 282,00 & 208,04 & - \\
\hline
\end{tabular}


Tabela 13. Ocorrência de geadas em épocas críticas para trigo, no Oeste do Paraná. Período: 21 anos (1974/1994)-Estação Agrometeorológica IAPAR Palotina-PR.

\begin{tabular}{|c|c|c|c|c|}
\hline & \multicolumn{3}{|c|}{ Dias de ocorrência } & $\begin{array}{c}\text { Temp. }{ }^{\circ} \text { C } \\
\text { Ano* }\end{array}$ \\
\hline 1975 & Junho & Julho & Agosto & $-5,2$ \\
\hline 1976 & - & 18 & - & -2 \\
\hline 1978 & 1 & 10,15 & - & 2,4 \\
\hline 1979 & - & 17 & - & -1 \\
\hline 1981 & 19 & 21 & - & $-3,2$ \\
\hline 1984 & - & 22 & 25 & $-2,8$ \\
\hline 1987 & 24 & - & - & $-1,2$ \\
\hline 1988 & 4 & 11,21 & - & $-2,8$ \\
\hline 1989 & - & 5 & - & $-1,8$ \\
\hline 1990 & - & 31 & - & $-1,5$ \\
\hline 1991 & - & - & 2 & $-2,2$ \\
\hline 1992 & - & 19 & - & 0,8 \\
\hline 1993 & - & 15 & 1 & $-2,6$ \\
\hline 1994 & 27 & 10 & - & $-2,7$ \\
\hline
\end{tabular}

* Anos não relacionados não apresentaram geadas nos meses citados. 
Tabela 14. Coeficiente técnico e balanço energético na produção de trigo, 1991.

\begin{tabular}{|c|c|c|c|c|c|c|c|c|}
\hline Especificação & Un & Quant & $\mathrm{T} 1$ & $\mathrm{~T} 2$ & T3 & T4 & T5 & T6 \\
\hline Semente-Trigo & $\mathrm{kg}$ & 180 & 540,00 & 540,00 & 540,00 & 540,00 & 540,00 & 540,00 \\
\hline Adubação-base & $\mathrm{kg}$ & 200 & 214,40 & 214,40 & 214,40 & 214,40 & 214,40 & 214,40 \\
\hline Adubação-cobertura & $\mathrm{kg}$ & 30 & 447,90 & 895,80 & 447,90 & & 895,80 & 447,90 \\
\hline Herbicida (Glifosato) & 1 & 1,5 & & & 71,94 & & 71,94 & 71,94 \\
\hline Herbicida $(2,4-D)$ & 1 & 1,5 & & & 100,41 & & 100,41 & 100,41 \\
\hline Semente-Crotalária & $\mathrm{kg}$ & 25 & 20,96 & 20,96 & & 20,96 & & \\
\hline Fung.(Propiconazole) & 1 & 0,5 & 8,11 & 8,11 & 8,11 & 8,11 & 8,11 & 8,11 \\
\hline \multicolumn{9}{|c|}{ Operações tratorizadas: } \\
\hline Aplicação herbicida & ha & 1 & & & 0,94 & & 0,94 & 0,94 \\
\hline Adubação cobertura & ha & 1 & 0,94 & 0,94 & 0,94 & & 0,94 & 0,94 \\
\hline Aplicação fungicida & ha & 1 & 0,94 & 0,94 & 0,94 & 0,94 & 0,94 & 0,94 \\
\hline Semeadura trigo & ha & 1 & 10,49 & 10,49 & 10,49 & 10,49 & 10,49 & 10,49 \\
\hline Semeadura/rolagem & ha & 1 & 18,43 & 18,43 & & 18,43 & & \\
\hline Total energia cultural & \multicolumn{2}{|c|}{ mcal ha ${ }^{-1}$} & 1.262 & 1.710 & 1.396 & 813 & 1.651 & 1.396 \\
\hline
\end{tabular}


Tabela 15. Coeficiente técnico e balanço energético na produção de trigo, 1992.

\begin{tabular}{|c|c|c|c|c|c|c|c|c|}
\hline Especificação & Un & Quant & $\mathrm{T} 1$ & $\mathrm{~T} 2$ & T3 & T4 & T5 & T6 \\
\hline Semente-Trigo & $\mathrm{kg}$ & 180 & 540,00 & 540,00 & 540,00 & $\begin{array}{c}540,0 \\
0\end{array}$ & 540,00 & 540,00 \\
\hline Adubação-base & $\mathrm{kg}$ & 200 & 214,40 & 214,40 & 214,40 & $\begin{array}{c}214,4 \\
0\end{array}$ & 214,40 & 214,40 \\
\hline Adubação-cobertura & $\mathrm{kg}$ & 30 & 447,90 & 895,80 & 441,00 & & 882,00 & 441,00 \\
\hline Herbicida-Glifosato & 1 & 1,5 & 71,94 & 71,94 & 71,94 & 71,94 & 71,94 & 71,94 \\
\hline Herbicida-2,4-D & 1 & 1,5 & 100,41 & 100,41 & 100,41 & $\begin{array}{c}100,4 \\
1\end{array}$ & 100,41 & 100,41 \\
\hline Fung.-Propiconazole & 1 & 0,5 & 8,11 & 8,11 & 8,11 & 8,11 & 8,11 & 8,11 \\
\hline Inseticida-Pirimicarb & $\mathrm{kg}$ & 0,15 & 5,57 & 5,57 & 5,57 & 5,57 & 5,57 & 5,57 \\
\hline Colheita & $\mathrm{h}$ & 1 & 187,13 & 187,13 & 187,13 & $\begin{array}{c}187,1 \\
3\end{array}$ & 187,13 & 187,13 \\
\hline \multicolumn{9}{|c|}{ Operações tratorizadas: } \\
\hline Aplicação herbicida & ha & 1 & 0,94 & 0,94 & 0,94 & 0,94 & 0,94 & 0,94 \\
\hline Adubação cobertura & ha & 1 & 0,94 & 0,94 & 0,94 & & 0,94 & 0,94 \\
\hline Aplicação inseticida & ha & 1 & 0,94 & 0,94 & 0,94 & 0,94 & 0,94 & 0,94 \\
\hline Aplicação fungicida & ha & 1 & 0,94 & 0,94 & 0,94 & 0,94 & 0,94 & 0,94 \\
\hline Semeadura trigo & ha & 1 & 10,49 & 10,49 & 10,49 & 10,49 & 10,49 & 10,49 \\
\hline \multicolumn{2}{|c|}{$\mathrm{A}=$ Total energia cultural } & mcal ha ${ }^{-1}$ & 1.590 & 2.038 & 1.590 & 1.141 & 2.038 & 1.590 \\
\hline \multicolumn{2}{|c|}{$\mathrm{B}=$ Rendimento de grãos } & $\mathrm{kg} \mathrm{ha}^{-1}$ & 3.250 & 3.466 & 3.132 & 3.000 & 3.285 & 3.167 \\
\hline \multicolumn{2}{|c|}{ C=Valor calorimétrico (grãos) } & mcal.ha ${ }^{-1}$ & 10.676 & 11.386 & 10.289 & 9.855 & 10.791 & 10.404 \\
\hline \multicolumn{2}{|c|}{ B. $A^{-1}=$ Eficiência cultural } & mcal & 2,04 & 1,70 & 1,97 & 2,63 & 1,61 & 1,99 \\
\hline \multicolumn{2}{|c|}{ C. $A^{-1}=$ Eficiência energética } & mcal.mcal ${ }^{-1}$ & 6,71 & 5,59 & 6,47 & 8,64 & 5,30 & 6,54 \\
\hline
\end{tabular}


Tabela 16. Coeficiente técnico e balanço energético na produção de trigo, 1993.

\begin{tabular}{|c|c|c|c|c|c|c|c|c|}
\hline Especificação & Un. & Quant & T 1 & $\mathrm{~T} 2$ & T3 & $\mathrm{T} 4$ & T5 & T6 \\
\hline Semente-Trigo & $\mathrm{kg}$ & 180 & 540,00 & 540,00 & 540,00 & 540,00 & 540,00 & 540,00 \\
\hline Adubação-base & $\mathrm{kg}$ & 200 & 214,40 & 214,40 & 214,40 & 214,40 & 214,40 & 214,40 \\
\hline Adubação-cobertura & $\mathrm{kg}$ & 30 & 447,90 & 895,80 & 447,90 & & 895,80 & 447,90 \\
\hline Herbicida-Glifosato & 1 & 1,5 & & & 71,94 & & 71,94 & 71,94 \\
\hline Herbicida-2,4-D & 1 & 1,5 & & & 100,41 & & 100,41 & 100,41 \\
\hline Semente-Crotalária & $\mathrm{kg}$ & 25 & 20,96 & 20,96 & & 20,96 & & \\
\hline Fungicida Tebuconazole & 1 & 0,75 & 12,17 & 12,17 & 12,17 & 12,17 & 12,17 & 12,17 \\
\hline Inseticida-Pirimicarb & $\mathrm{kg}$ & 0,15 & 5,57 & 5,57 & 5,57 & 5,57 & 5,57 & 5,57 \\
\hline Colheita & $\mathrm{h}$ & 1 & 187,13 & 187,13 & 187,13 & 187,13 & 187,13 & 187,13 \\
\hline \multicolumn{9}{|c|}{ Operações tratorizadas: } \\
\hline Aplicação herbicida & ha & 1 & & & 0,94 & & 0,94 & 0,94 \\
\hline Adubação cobertura & ha & 1 & 0,94 & 0,94 & 0,94 & & 0,94 & 0,94 \\
\hline Aplicação inseticida & ha & 1 & 0,94 & 0,94 & 0,94 & 0,94 & 0,94 & 0,94 \\
\hline Aplicação fungicida & ha & 1 & 0,94 & 0,94 & 0,94 & 0,94 & 0,94 & 0,94 \\
\hline Semeadura trigo & ha & 1 & 10,49 & 10,49 & 10,49 & 10,49 & 10,49 & 10,49 \\
\hline Semeadura/rolagem & ha & & 18,28 & 18,28 & 18,28 & 18,28 & 18,28 & 18,28 \\
\hline \multicolumn{2}{|c|}{$\mathrm{A}=$ Total energia cultural } & mcal ha ${ }^{-1}$ & 1.460 & 1.908 & 1.612 & 1.011 & 2.060 & 1.612 \\
\hline \multicolumn{2}{|c|}{ B=Rendimento de grãos } & $\mathrm{kg} \mathrm{ha}^{-1}$ & 2.609 & 2.694 & 2.232 & 1.888 & 2.520 & 2.595 \\
\hline \multicolumn{2}{|c|}{$\mathrm{C}=$ Valor calorimétrico (grãos) } & mcal.ha ${ }^{-1}$ & 8.571 & 8.850 & 7.332 & 6.202 & 8.278 & 8.525 \\
\hline \multicolumn{2}{|c|}{ B. $A^{-1}=$ Eficiência cultural } & mcal & 1,79 & 1,41 & 1,39 & 1,87 & 1,22 & 1,61 \\
\hline \multicolumn{2}{|c|}{ C. $A^{-1}=$ Eficiência energética } & mcal.mcal ${ }^{-1}$ & 5,87 & 4,64 & 4,55 & 6,14 & 4,02 & 5,29 \\
\hline
\end{tabular}


Tabela 17. Coeficiente técnico e balanço energético na produção de trigo, 1994.

\begin{tabular}{|c|c|c|c|c|c|c|c|c|}
\hline Especificação & Un & Quant & T1 & T2 & T3 & T4 & T5 & T6 \\
\hline Semente-Trigo & $\mathrm{kg}$ & 180 & 540,00 & 540,00 & 540,00 & 540,00 & 540,00 & 540,00 \\
\hline Adubação-base & $\mathrm{kg}$ & 200 & 214,40 & 214,40 & 214,40 & 214,40 & 214,40 & 214,40 \\
\hline Adubação-cobertura & $\mathrm{kg}$ & 30 & 447,90 & 895,80 & 447,90 & & 895,80 & 447,90 \\
\hline Herbicida-Glifosato & 1 & 1,5 & 71,94 & 71,94 & 71,94 & 71,94 & 71,94 & 71,94 \\
\hline Herbicida-2,4-D & 1 & 1,5 & 100,41 & 100,41 & 100,41 & 100,41 & 100,41 & 100,41 \\
\hline Fung.-Tebuconazole & 1 & 0,75 & 12,17 & 12,17 & 12,17 & 12,17 & 12,17 & 12,17 \\
\hline Inseticida-Pirimicarb & $\mathrm{kg}$ & 0,15 & 5,57 & 5,57 & 5,57 & 5,57 & 5,57 & 5,57 \\
\hline \multicolumn{9}{|c|}{ Operações tratorizadas: } \\
\hline Aplicação herbicida & ha & 1 & 0,94 & 0,94 & 0,94 & 0,94 & 0,94 & 0,94 \\
\hline Aplicação inseticida & ha & 1 & 0,94 & 0,94 & 0,94 & 0,94 & 0,94 & 0,94 \\
\hline Adubação cobertura & ha & 1 & 0,94 & 0,94 & 0,94 & & 0,94 & 0,94 \\
\hline Aplicação fungicida & ha & 1 & 0,94 & 0,94 & 0,94 & 0,94 & 0,94 & 0,94 \\
\hline Semeadura trigo & ha & 1 & 10,49 & 10,49 & 10,49 & 10,49 & 10,49 & 10,49 \\
\hline \multicolumn{3}{|l|}{ Total energia cultural } & 1.406 & 1.855 & 1.406 & 958 & 1.855 & 1.406 \\
\hline
\end{tabular}


Tabela 18. Coeficiente técnico e balanço energético na produção de trigo, 1995.

\begin{tabular}{|c|c|c|c|c|c|c|c|c|}
\hline Especificação & Un & Quant & $\mathrm{T} 1$ & $\mathrm{~T} 2$ & T3 & T4 & T5 & T6 \\
\hline Semente-Trigo & $\mathrm{kg}$ & 180 & 540,00 & 540,00 & 540,00 & 540,00 & 540,00 & 540,00 \\
\hline Adubação-base & $\mathrm{kg}$ & 200 & 214,40 & 214,40 & 214,40 & 214,40 & 214,40 & 214,40 \\
\hline Adubação-cobertura & $\mathrm{kg}$ & 30 & 447,90 & 895,80 & 447,90 & & 895,80 & 447,90 \\
\hline Herbicida-Glifosato & 1 & 1,5 & & & 71,94 & & 71,94 & 71,94 \\
\hline Herbicida $(2,4-D)$ & 1 & 1,5 & & & 100,41 & & 100,41 & 100,41 \\
\hline Semente-Crotalária & $\mathrm{kg}$ & 25 & 20,96 & 20,96 & & 20,96 & & \\
\hline Fung.(Tebuconazole) & 1 & 0,75 & 12,17 & 12,17 & 12,17 & 12,17 & 12,17 & 12,17 \\
\hline Inseticida (Pirimicarb) & $\mathrm{kg}$ & 0,15 & 5,57 & 5,57 & 5,57 & 5,57 & 5,57 & 5,57 \\
\hline Colheita & $\mathrm{h}$ & 1 & 187,13 & 187,13 & 187,13 & 187,13 & 187,13 & 187,13 \\
\hline \multicolumn{9}{|c|}{ Operações tratorizadas: } \\
\hline Aplicação herbicida & ha & 1 & & & 0,94 & & 0,94 & 0,94 \\
\hline Aplicação inseticida & ha & 1 & 0,94 & 0,94 & 0,94 & 0,94 & 0,94 & 0,94 \\
\hline Adubação cobertura & ha & 1 & 0,94 & 0,94 & 0,94 & & 0,94 & 0,94 \\
\hline Aplicação fungicida & ha & 1 & 0,94 & 0,94 & 0,94 & 0,94 & 0,94 & 0,94 \\
\hline Semeadura trigo & ha & 1 & 10,49 & 10,49 & 10,49 & 10,49 & 10,49 & 10,49 \\
\hline Semeadura/rolagem & ha & 1 & 18,28 & 18,28 & & 18,28 & & \\
\hline \multicolumn{2}{|c|}{$\mathrm{A}=$ Total energia cultural } & mcal ha ${ }^{-1}$ & 1.460 & 1.908 & 1.594 & 1.011 & 2.032 & 1.594 \\
\hline \multicolumn{2}{|c|}{$\overline{\mathrm{B}}=$ =Rendimento de grãos } & $\mathrm{kg} \mathrm{ha}^{-1}$ & 1.387 & 1326 & 1.194 & 1.430 & 1.190 & 1.073 \\
\hline \multicolumn{2}{|c|}{$\mathrm{C}=$ Valor calorimétrico (grãos) } & mcal.ha ${ }^{-1}$ & 4.556 & 4.356 & 3.922 & 4.698 & 3.912 & 3.525 \\
\hline \multicolumn{2}{|c|}{ B. $A^{-1}=$ Eficiência cultural } & mcal & 0,95 & 0,70 & 0,75 & 1,41 & 0,59 & 0,67 \\
\hline \multicolumn{2}{|c|}{ C. $\mathrm{A}^{-1}=$ Eficiência energética } & mcal.mcal ${ }^{-1}$ & 3,12 & 2,28 & 2,46 & 4,65 & 1,93 & 2,21 \\
\hline
\end{tabular}


Tabela 19. Coeficiente técnico e balanço energético na produção de soja, 1992.

\begin{tabular}{|c|c|c|c|c|c|c|c|c|}
\hline Especificação & Un. & Quant & T1 & $\mathrm{T} 2$ & T3 & T4 & T5 & T6 \\
\hline Escarificação do solo & ha & 1 & 10,38 & 10,38 & 10,38 & 10,38 & 10,38 & 10,38 \\
\hline Grade niveladora & ha & 1 & 7,79 & 7,79 & 7,79 & 7,79 & 7,79 & 7,79 \\
\hline Semente & $\mathrm{kg}$ & 90 & 682,56 & 682,56 & 682,56 & 682,56 & 682,56 & 682,56 \\
\hline Fertilizante $(0-20-20)$ & $\mathrm{kg}$ & 200 & 80,00 & 80,00 & 80,00 & 80,00 & 80,00 & 80,00 \\
\hline $\begin{array}{l}\text { Herb: Triflularina } \\
\text { +Imazaquin }\end{array}$ & $\begin{array}{l}1 \\
1\end{array}$ & $\begin{array}{l}2 \\
1 \\
\end{array}$ & & & $\begin{array}{l}88,92 \\
14,99 \\
\end{array}$ & & $\begin{array}{l}88,92 \\
14,99 \\
\end{array}$ & $\begin{array}{l}88,92 \\
14,99 \\
\end{array}$ \\
\hline Inseticida (Endossulfã) & 1 & 1,6 & 48,67 & 48,67 & 48,67 & 48,67 & 48,67 & 48,67 \\
\hline Capina & $\mathrm{D} / \mathrm{H}$ & 2 & 8,00 & 8,00 & & 8,00 & & \\
\hline Baculovirus & dose & 2 & 1,00 & 1,00 & 1,00 & 1,00 & 1,00 & 1,00 \\
\hline Colheita & ha & 1 & 187,13 & 187,13 & 187,13 & 187,13 & 187,13 & 187,13 \\
\hline \multicolumn{9}{|c|}{ Operações tratorizadas: } \\
\hline Aplicação herbicida & ha & 1 & & & 0,94 & & 0,94 & 0,94 \\
\hline Aplicação inseticida & ha & 1 & 3,76 & 3,76 & 3,76 & 3,76 & 3,76 & 3,76 \\
\hline \multicolumn{2}{|c|}{$\mathrm{A}=$ Total en ergia cultural } & mcal ha $^{-1}$ & 1.029 & 1.029 & 1.126 & 1.029 & 1.126 & 1.126 \\
\hline \multicolumn{2}{|c|}{$\mathrm{B}=$ Rendimento de grãos } & $\mathrm{kg} \mathrm{ha}^{-1}$ & 2.575 & 2.593 & 2.427 & 2.555 & 2.233 & 2.303 \\
\hline \multicolumn{2}{|c|}{$\bar{C}=$ Valor calorimétrico (grãos) } & mcal.ha $^{-1}$ & 10.357 & 10.429 & 9.761 & 10.276 & 8.981 & 9.263 \\
\hline \multicolumn{2}{|c|}{$\mathrm{B} \cdot \mathrm{A}^{-1}=$ Eficiência cultural } & mcal & 2,50 & 2,52 & 2,16 & 2,48 & 1,98 & 2,05 \\
\hline \multicolumn{2}{|c|}{ C. $\mathrm{A}^{-1}=$ Eficiência energética } & $\mathrm{mcal}_{\mathrm{mcal}}{ }^{-1}$ & 10,06 & 10,14 & 8,67 & 9,99 & 7,98 & 8,23 \\
\hline
\end{tabular}


Tabela 20. Coeficiente técnico e balanço energético na produção de soja, 1993.

\begin{tabular}{|c|c|c|c|c|c|c|c|c|}
\hline Especificação & Un. & Quant & T1 & $\mathrm{T} 2$ & T3 & T4 & T5 & T6 \\
\hline Escarificação do solo & ha & 1 & & & & & & 10,38 \\
\hline Grade niveladora & ha & 1 & & & & & & 7,79 \\
\hline Semente & $\mathrm{kg}$ & 90 & & & & & & 682,56 \\
\hline Fertilizante $(0-20-20)$ & $\mathrm{kg}$ & 200 & & & & & & 80,00 \\
\hline $\begin{array}{l}\text { Herb: triflularina }+ \\
\text { Imazaquin }\end{array}$ & $\begin{array}{l}1 \\
1\end{array}$ & $\begin{array}{l}2 \\
1 \\
\end{array}$ & & & & & & $\begin{array}{l}88,92 \\
14,99 \\
\end{array}$ \\
\hline Inseticida (Endossulfã) & 1 & 1,6 & & & & & & 48,67 \\
\hline Baculovirus & dose & 2 & & & & & & 1,00 \\
\hline Colheita & ha & 1 & & & & & & 187,13 \\
\hline \multicolumn{9}{|c|}{ Operações tratorizadas: } \\
\hline Aplicação herbicida & & & & & & & & 0,94 \\
\hline Aplicação inseticida & & & & & & & & 3,76 \\
\hline \multicolumn{2}{|c|}{$\mathrm{A}=$ Total energia cultural } & mcal ha ${ }^{-1}$ & & & & & & 1.126 \\
\hline \multicolumn{2}{|c|}{$\mathrm{B}=$ Rendimento de grãos } & $\mathrm{kg} \mathrm{ha}^{-1}$ & & & & & & 2.655 \\
\hline \multicolumn{2}{|c|}{$\mathrm{C}=$ Valor calorimétrico (grãos) } & mcal.ha ${ }^{-1}$ & & & & & & 10.678 \\
\hline \multicolumn{2}{|c|}{ B. $A^{-1}=$ Eficiência cultural } & mcal & & & & & & 2,36 \\
\hline \multicolumn{2}{|c|}{ C. $A^{-1}=$ Eficiência energética } & mcal.mcal ${ }^{-1}$ & & & & & & 9,48 \\
\hline
\end{tabular}


Tabela 21. Coeficiente técnico e balanço energético na produção de soja, 1994.

\begin{tabular}{|c|c|c|c|c|c|c|c|c|}
\hline Especificação & Un. & Quant & $\mathrm{T} 1$ & $\mathrm{~T} 2$ & T3 & $\mathrm{T} 4$ & T5 & T6 \\
\hline Herb.manejo (Glifosato) & 1 & 1,5 & 71,94 & 71,94 & 71,94 & 71,94 & 71,94 & 71,94 \\
\hline Semente & $\mathrm{kg}$ & 90 & 682,56 & 682,56 & 682,56 & 682,56 & 682,56 & 682,56 \\
\hline Fertilizante $(0-20-20)$ & $\mathrm{kg}$ & 200 & 80,00 & 80,00 & 80,00 & 80,00 & 80,00 & 80,00 \\
\hline Herbicida (Imazaquin) & 1 & 1 & & & 14,99 & & 14,99 & 14,99 \\
\hline Inseticida (Endossulfã) & 1 & 1,6 & 48,67 & 48,67 & 48,67 & 48,67 & 48,67 & 48,67 \\
\hline Capina & $\mathrm{DH}$ & 2 & 8,00 & 8,00 & & 8,00 & & \\
\hline Baculovirus & dose & 2 & 1,00 & 1,00 & 1,00 & 1,00 & 1,00 & 1,00 \\
\hline Colheita & ha & 1 & 187,13 & 187,13 & 187,13 & 187,13 & 187,13 & 187,13 \\
\hline \multicolumn{9}{|c|}{ Operações tratorizadas: } \\
\hline Aplicação herbicida & ha & 1 & 1,88 & 1,88 & 1,88 & 1,88 & 1,88 & 1,88 \\
\hline Aplicação inseticida & ha & 1 & 3,76 & 3,76 & 3,76 & 3,76 & 3,76 & 3,76 \\
\hline \multicolumn{2}{|c|}{$\mathrm{A}=$ Total energia cultural } & mcal ha-1 & 1.085 & 1.085 & 1.092 & 1.085 & 1.092 & 1.092 \\
\hline \multicolumn{2}{|c|}{$\mathrm{B}=$ Rendimento de grãos } & $\mathrm{kg} \mathrm{ha}^{-1}$ & 3.286 & 3.602 & 3.133 & 3.301 & 3.248 & 3.092 \\
\hline \multicolumn{2}{|c|}{ C=Valor calorimétrico (grãos) } & mcal.ha ${ }^{-1}$ & 13.216 & 14.487 & 12.600 & 13.277 & 13.065 & 12.436 \\
\hline \multicolumn{2}{|c|}{ B. $A^{-1}=$ Eficiência cultural } & mcal & 3,03 & 3,32 & 2,87 & 3,04 & 2,97 & 2,83 \\
\hline \multicolumn{2}{|c|}{ C. $A^{-1}=$ Eficiência energética } & mcal.mcal ${ }^{-1}$ & 12,18 & 13,35 & 11,54 & 12,24 & 11,96 & 11,39 \\
\hline
\end{tabular}

Tabela 22. Coeficiente técnico e balanço energético na produção de soja, 1995.

\begin{tabular}{|c|c|c|c|c|c|c|c|c|}
\hline Especifícação & Un. & Quant & $\mathrm{Tl}$ & $\mathrm{T} 2$ & T3 & T4 & T5 & T6 \\
\hline Herb.manejo (Glifosato) & 1 & 1,5 & & & & & & 71,94 \\
\hline Semente & $\mathrm{kg}$ & 90 & & & & & & 682,56 \\
\hline Fertilizante (0-20-20) & $\mathrm{kg}$ & 200 & & & & & & 80,00 \\
\hline Herbicida (Imazaquin) & 1 & 1 & & & & & & 14,99 \\
\hline Inseticida (Endossulfã) & 1 & 1,6 & & & & & & 48,67 \\
\hline Baculovirus & dose & 2 & & & & & & 1,00 \\
\hline Colheita & ha & 1 & & & & & & 187,13 \\
\hline \multicolumn{9}{|c|}{ Operações tratorizadas: } \\
\hline Aplicação herbicida & & & & & & & & 1,88 \\
\hline Aplicação inseticida & & & & & & & & 3,76 \\
\hline \multicolumn{2}{|c|}{$\mathrm{A}=$ Total energia cultural } & mcal ha. $^{-1}$ & & & & & & 1.092 \\
\hline \multicolumn{2}{|l|}{$\mathrm{B}=$ Rendimento de grãos } & $\mathrm{kg} \mathrm{ha}^{-1}$ & & & & & & 2.880 \\
\hline \multicolumn{2}{|c|}{$\begin{array}{l}\mathrm{C}=\text { Valor calorimétrico (grãos) } \\
\end{array}$} & mcal.ha $^{-1}$ & & & & & & 11.583 \\
\hline \multicolumn{2}{|c|}{ B. $A^{-1}=$ Eficiência cultural } & mcal & & & & & & 2,64 \\
\hline \multicolumn{2}{|c|}{ C. $A^{-1}=$ Eficiência energética } & mcal.mcal ${ }^{-1}$ & & & & & & 10,61 \\
\hline
\end{tabular}


Tabela 23. Coeficiente técnico e energético na produção de soja, 1996.

\begin{tabular}{|c|c|c|c|c|c|c|c|c|}
\hline Especificação & Un. & Quant & $\mathrm{T} 1$ & $\mathrm{~T} 2$ & T3 & $\mathrm{T} 4$ & T5 & T6 \\
\hline Herb.manejo (Glifosato) & 1 & 1,5 & 71,94 & 71,94 & 71,94 & 71,94 & 71,94 & 71,94 \\
\hline Semente & $\mathrm{kg}$ & 90 & 682,56 & 682,56 & 682,56 & 682,56 & 682,56 & 682,56 \\
\hline Fertilizante $(0-20-20)$ & $\mathrm{kg}$ & 200 & 80,00 & 80,00 & 80,00 & 80,00 & 80,00 & 80,00 \\
\hline Herbicida (Imazaquin) & 1 & 1 & & & 14,99 & & 14,99 & 14,99 \\
\hline Inseticida (Endossulfã) & 1 & 1,6 & 48,67 & 48,67 & 48,67 & 48,67 & 48,67 & 48,67 \\
\hline Capina & $\mathrm{DH}$ & 2 & 8,00 & 8,00 & & 8,00 & & \\
\hline Baculovirus & dose & 2 & 1,00 & 1,00 & 1,00 & 1,00 & 1,00 & 1,00 \\
\hline Colheita & ha & 1 & 187,13 & 187,13 & 187,13 & 187,13 & 187,13 & 187,13 \\
\hline \multicolumn{9}{|l|}{ Operações tratorizadas: } \\
\hline Aplicação herbicida & ha & 1 & 1,88 & 1,88 & 1,88 & 1,88 & 1,88 & 1,88 \\
\hline Aplicação inseticida & ha & 1 & 3,76 & 3,76 & 3,76 & 3,76 & 3,76 & 3,76 \\
\hline \multicolumn{2}{|c|}{$\mathrm{A}=$ Total energia cultural } & mcal ha ${ }^{-1}$ & 1.085 & 1.085 & 1.092 & 1.085 & 1.092 & 1.092 \\
\hline \multicolumn{2}{|c|}{$\mathrm{B}=$ Rendimento de grãos } & $\mathrm{kg} \mathrm{ha}^{-1}$ & 3.581 & 3.607 & 3.201 & 3.609 & 3.140 & 3.288 \\
\hline \multicolumn{2}{|c|}{$\mathrm{C}=$ Valor calorimétrico (grãos) } & mcal.ha $^{-1}$ & 14.403 & 14.507 & 12.744 & 14.515 & 12.291 & 13.224 \\
\hline \multicolumn{2}{|c|}{ B. $A^{-1}=$ Eficiência cultural } & mcal & 3,30 & 3,32 & 2,93 & 3,33 & 2,88 & 3,01 \\
\hline \multicolumn{2}{|c|}{ C. $A^{-1}=$ Eficiência energética } & mcal.mcal ${ }^{-1}$ & 13,28 & 13,37 & 11,67 & 13,38 & 11,26 & 12,11 \\
\hline
\end{tabular}


Tabela 24. Coeficiente técnico e balanço energético na produção de milho, 1993.

\begin{tabular}{|c|c|c|c|c|c|c|c|c|}
\hline Especificação & Un. & Quant & T1 & $\mathrm{T} 2$ & T3 & T4 & T5 & T6 \\
\hline Escarificação do solo & ha & 1 & 10,38 & 10,38 & 10,38 & 10,38 & 10,38 & - \\
\hline Grade niveladora & ha & 1 & 7,79 & 7,79 & 7,79 & 7,79 & 7,79 & - \\
\hline Semente & $\mathrm{kg}$ & 20 & 496,12 & 496,12 & 496,12 & 496,12 & 496,12 & - \\
\hline Semeadura (matraca) & $\mathrm{D} / \mathrm{H}$ & 2 & 8,00 & 8,00 & 8,00 & 8,00 & 8,00 & - \\
\hline Raleação do estande & $\mathrm{D} / \mathrm{H}$ & 6 & 24,00 & 24,00 & 24,00 & 24,00 & 24,00 & - \\
\hline Fertilizante $(4-30-10)$ & $\mathrm{kg}$ & 200 & 214,40 & 214,40 & 214,40 & 214,40 & 214,40 & - \\
\hline Herb(Atrazine + simazine) & 1 & 4 & 199,82 & 199,82 & 199,82 & 199,82 & 199,82 & - \\
\hline Inseticida (Clorspirifós) & 1 & 1,6 & 66,75 & 66,75 & 66,75 & 66,75 & 66,75 & - \\
\hline Colheita & ha & 1 & 280.70 & 280.70 & 280.70 & 280.70 & 280.70 & - \\
\hline Sulfato de amônio & $\mathrm{kg}$ & 450 & 1.323, & 1.323, & 1.323, & 1.323, & 1.323, & - \\
\hline \multicolumn{9}{|c|}{ Operações tratorizadas } \\
\hline Adubação cobertura & ha & 1 & 2,36 & 2,36 & 2,36 & 2,36 & 2,36 & \\
\hline Aplicação herbicida & ha & 1 & 0,94 & 0,94 & 0,94 & 0,94 & 0,94 & - \\
\hline Aplicação inseticida & ha & 1 & 1,88 & 1,88 & 1,88 & 1,88 & 1,88 & - \\
\hline \multicolumn{2}{|l|}{$A=$ Total energia cultural } & mcal ha ${ }^{-1}$ & 2.636 & 2.636 & 2.636 & 2.636 & 2.636 & - \\
\hline \multicolumn{2}{|l|}{ "B=Rendimento de grãos } & $\mathrm{kg} \mathrm{ha}^{-1}$ & 8.014 & 8.388 & 8.058 & 8.001 & 8.180 & - \\
\hline \multicolumn{2}{|c|}{$\mathrm{C}=$ Valor calorimétrico (grãos) } & mcal.ha $^{-1}$ & 27.912 & 29.215 & 28.066 & 27.868 & 28.491 & - \\
\hline \multicolumn{2}{|l|}{ B. $A^{-1}=$ Eficiência cultural } & mcal & 3,04 & 3,18 & 3,06 & 3,04 & 3,10 & 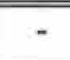 \\
\hline \multicolumn{2}{|c|}{ C. $A^{-1}=$ Eficiência energética } & mcal. $\mathrm{mcal}^{-1}$ & 10,59 & 11,08 & 10,65 & 10,57 & 10,81 & - \\
\hline
\end{tabular}


Tabela 25. Coeficiente técnico e balanço energético na produção de milho, 1995.

\begin{tabular}{|c|c|c|c|c|c|c|c|c|}
\hline Especificação & Un. & Quant & $\mathrm{T} 1$ & $\mathrm{~T} 2$ & T3 & $\mathrm{T} 4$ & T5 & T6 \\
\hline Herb.manejo (Glifosato) & 1 & 1,5 & 71,94 & 71,94 & 71,94 & 71,94 & 71,94 & - \\
\hline Semente & $\mathrm{kg}$ & 20 & 496,12 & 496,12 & 496,12 & 496,12 & 496,12 & - \\
\hline Semeadura (matraca) & $\mathrm{D} / \mathrm{H}$ & 2 & 8,00 & 8,00 & 8,00 & 8,00 & 8,00 & - \\
\hline Raleação do estande & $\mathrm{D} / \mathrm{H}$ & 6 & 24,00 & 24,00 & 24,00 & 24,00 & 24,00 & - \\
\hline Fertilizante (4-30-10) & $\mathrm{kg}$ & 200 & 214,40 & 214,40 & 214,40 & 214,40 & 214,40 & - \\
\hline Herb(Atrazine+simazine) & 1 & 4 & 199,82 & 199,82 & 199,82 & 199,82 & 199,82 & - \\
\hline Inseticida (Clorspirifós) & 1 & 1,6 & 66,75 & 66,75 & 66,75 & 66,75 & 66,75 & - \\
\hline Colheita & ha & 1 & 280.70 & 280.70 & 280.70 & 280.70 & 280.70 & - \\
\hline Sulfato de amônio & $\mathrm{kg}$ & 450 & 1.323, & 1.323, & 1.323, & 1.323, & 1.323, & - \\
\hline Adubação cobertura & ha & 1 & 2,36 & 2,36 & 2,36 & 2,36 & 2,36 & - \\
\hline \multicolumn{9}{|c|}{ Operações tratorizadas } \\
\hline Aplicação herbicida & ha & 1 & 1,88 & 1,88 & 1,88 & 1,88 & 1,88 & - \\
\hline Aplicação inseticida & ha & 1 & 1,88 & 1,88 & 1,88 & 1,88 & 1,88 & - \\
\hline \multicolumn{2}{|c|}{$\mathrm{A}=$ Total energia cultural } & mcal ha ${ }^{-1}$ & 2.691 & 2.691 & 2.691 & 2.691 & 2.691 & - \\
\hline \multicolumn{2}{|l|}{ B=Rendimento de grãos } & $\mathrm{kg} \mathrm{ha}^{-1}$ & 5.428 & 5.296 & 4.213 & 4.861 & 4.432 & - \\
\hline \multicolumn{2}{|c|}{$\mathrm{C}=$ Valor calorimétrico (grãos) } & mcal.ha $^{-1}$ & 18.905 & 18.446 & 14.674 & 16.931 & 15.437 & - \\
\hline \multicolumn{2}{|c|}{ B. $A^{-1}=$ Eficiência cultural } & mcal & 2,02 & 1,97 & 1,57 & 1,81 & 1,65 & - \\
\hline \multicolumn{2}{|c|}{ C. $A^{-1}=$ Eficiência energética } & ${\mathrm{mcal} . \mathrm{mcal}^{-1}}^{-1}$ & 7,03 & 6,86 & 5,45 & 6,29 & 5,74 & - \\
\hline
\end{tabular}

